Portland State University

PDXScholar

$1-1-1983$

\title{
Effect of copper on cell division, nitrogen metabolism, morphology, and sexual reproduction in the life cycle of Closterium moniliferum (Chlorophyceae)
}

Erleen Svihovec Christenson

Portland State University

Follow this and additional works at: https://pdxscholar.library.pdx.edu/open_access_etds Let us know how access to this document benefits you.

\section{Recommended Citation}

Christenson, Erleen Svihovec, "Effect of copper on cell division, nitrogen metabolism, morphology, and sexual reproduction in the life cycle of Closterium moniliferum (Chlorophyceae)" (1983). Dissertations and Theses. Paper 54.

https://doi.org/10.15760/etd.54

This Dissertation is brought to you for free and open access. It has been accepted for inclusion in Dissertations and Theses by an authorized administrator of PDXScholar. Please contact us if we can make this document more accessible: pdxscholar@pdx.edu. 
EFFECT OF COPPER ON CELL DIVISION, NITROGEN METABOLISM, MORPHOLOGY, AND SEXUAL REPRODUCTION IN THE LIFE CYCLE OF CLOSTERIUM MONILIFERUM (CHLOROPHYCEAE)

\author{
by \\ ERLEEN SVIHOVEC CHRISTENSON
}

A dissertation submitted in partial fulfillment of the requirements for the degree of

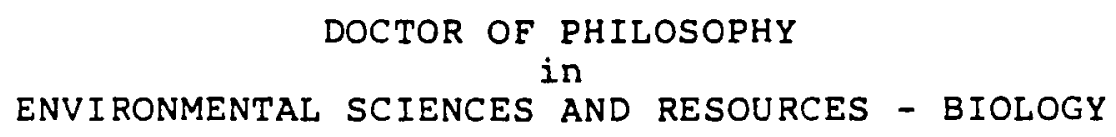

Portland State University

1983 
TO THE OFFICE OF GRADUATE STUDIES AND RESEARCH:

The members of the Committee approve the dissertation of Erleen Svihovec Christenson presented February 18, 1983.

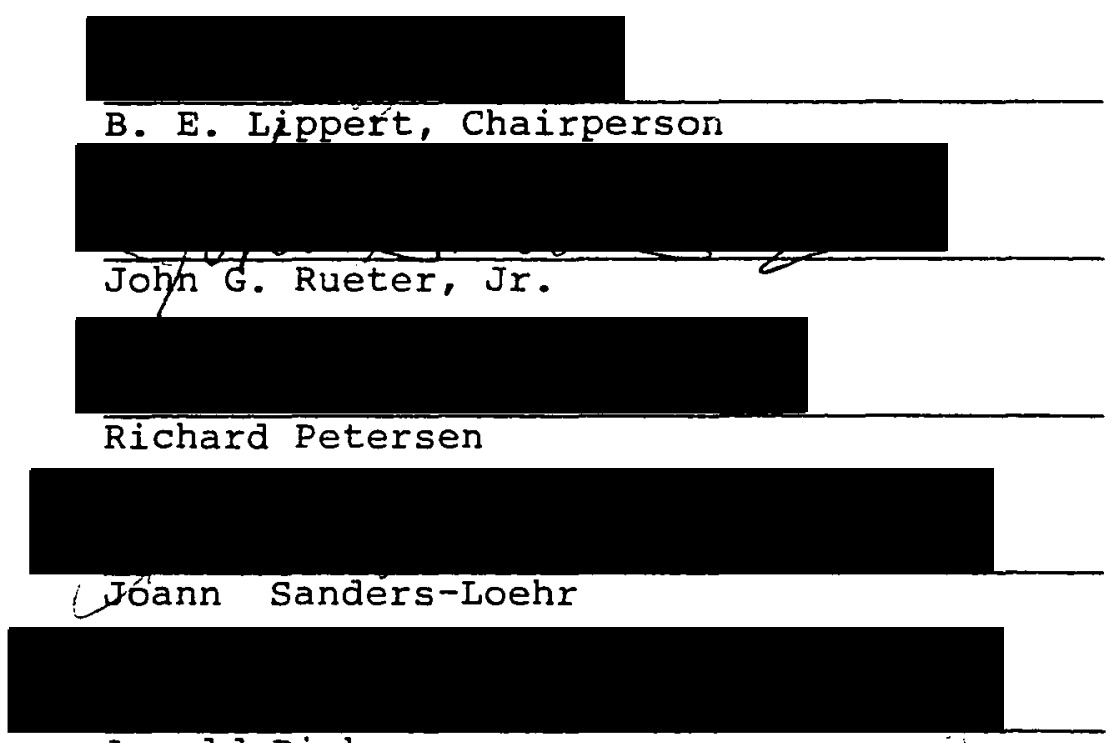

Arnold Pickar

APPROVED:

W. Herman Taylor, Head, Bzology Department

Robert O. Tinnin, Environmental Sciences Director

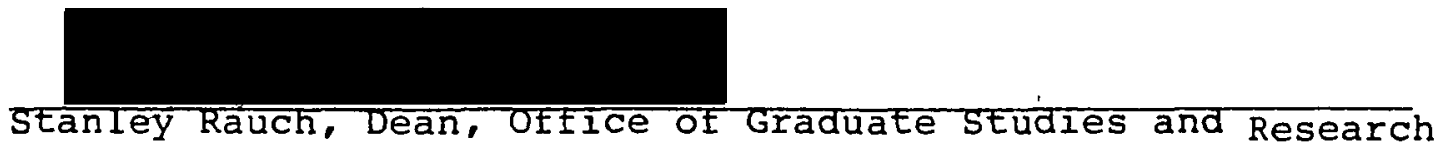


AN ABSTRACT OF THE DISSERTATION OF Erleen Svihovec

Christenson for the Doctor of Philosophy in Environmental

Sciences and Resources-Biology presented February 18, 1983.

Title: Effect of Copper on Cell Division, Nitrogen Metabolism and Sexual Reproduction in the Life Cycle of Closterium moniliferum (Chlorophyceae)

APPROVED BY MEMBERS OF THE THESIS COMMITTEE

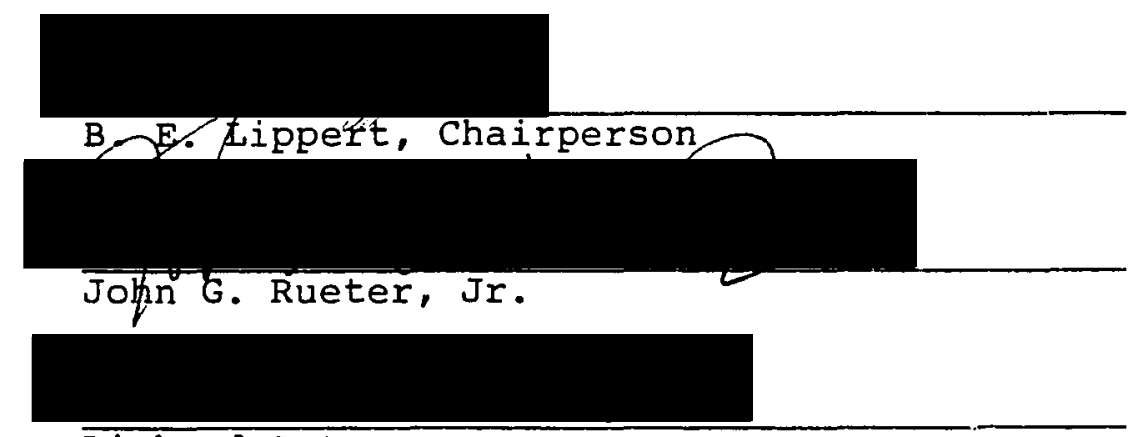

Richard Petersen

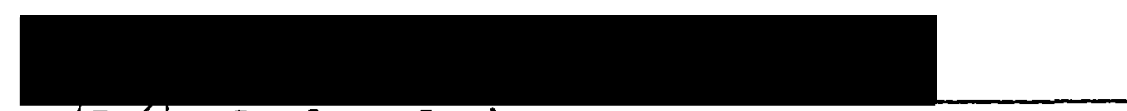

Joahn Sanders-Loehr

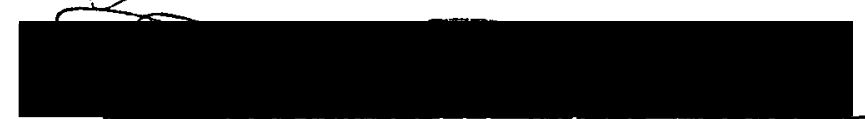

Arnold Pickar

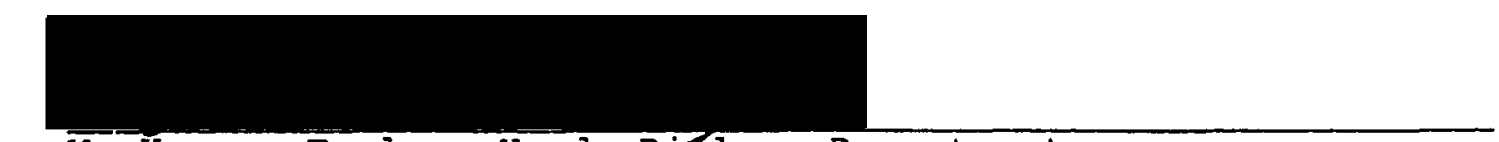

W. Herman Taylor, Head, Bjology Department

Robert O. Tinnin, Environmental Sciences Director

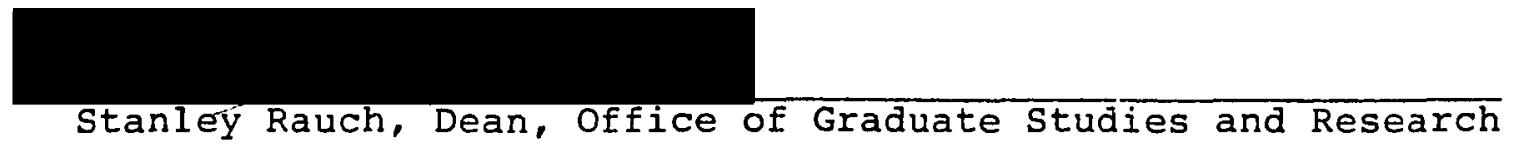


Additions of copper were shown to affect cell morphology, growth rates and nutrient uptake in closterium moniliferum. These parameters are interrelated in the total life cycle of the organism. It was found that the timing of events in the life cycle, including sexual reproduction, could be changed when copper was added. When increasing concentrations of copper were added to the growth medium. Closterium moniliferum exhibited a stimulatory, inhibitory, or toxic dose-response typical of organisms to trace metals. The stimulatory effect, occurring at $\mathrm{pCu}$ * 14.4, was demonstrated by an early increase in cell number, increased nitrate uptake, and early onset of sexual reproduction. The inhibitory effects of greater concentrations of copper (pCu* 12.1) were a longer lag phase, decreased nitrate uptake, and later onset of sexual reproduction. Light micrographs and scanning electron micrographs of normal and aberrant cells demonstrated the effect of copper on morphology .

It was demonstrated that the sexual phase in some srains of closterium moniliferum could be triggered by changes in the amount of nitrogen in the medium. Although it was expected that each cell would have a minimal cell quota (Q nitrogen/cell) before sexual reproduction occurred, work here demonstrated that $Q$ was not the critical factor in the initiation of the process. Sexual reproduction occurred at $Q=.05 \mathrm{micromoles}$ nitrogen $/ \mathrm{ccll}$ up to $.21 \mathrm{micro-}$ moles nitrogen/cell. Neither was cell density in batch 
cultures the critical factor. Sexual reproduction occurred in the range of $400 \mathrm{cells} / \mathrm{ml}$ up to $6100 \mathrm{cells} / \mathrm{ml}$. Different nitrogen sources gave different responses in the onset of sexual reproduction. Nitrate depletion, not. ammonia, appears to be the critical component in induction of sexual reproduction.

The actual effect of metals like copper on the population dynamics of Closterium moniliferum in natural environments is yet to be determined. The stimulatory effect on nitrate uptake by copper, and its accompanying earlier formation of zygotes, may have survival value for the organism since the zygotes become thick-walled and are not as subject to environmental perturbations as vegetative cells. 


\section{DEDICATION}

I dedicate this dissertation to my mom and dad, Otto and Ann Svihovec, who instilled in me a zest for learning, a desire to strive for excellence, and the North Dakota persistence that they exemplified. 


\section{ACKNOWLEDGEMENTS}

I wish to thank John Rueter for imparting his enthusiasm for research and for stimulating my brain to formulate hypotheses; Ed Lippert for serving as chairperson through the bureaucratic maze; Richard Petersen for many discussions which helped convince me that it was possible to hang on to sanity while in graduate school; Joann SandersLoehr and Arnold Pickar for their perspectives on this work and Wolfgang Fahrenbach for his expertise with the scanning electron microscope.

Most of all, I wish to thank my family who, willingly and unwillingly, have been participants in this project these $4 \frac{1}{2}$ years:

my daughter Roxanne, who didn't graduate from college before I did;

my daughter Samantha, who washed more dishes than she cares to count;

my son $C y$, who has been waiting to play ball.

I especially thank my husband Wes, who deserves a medal for forbearance, tolerance, solicitude and support. He deservedly shares my moment of accomplishment, as he helped me prove the resiliency of the human spirit. 
TABLE OF CONTENTS

PAGE

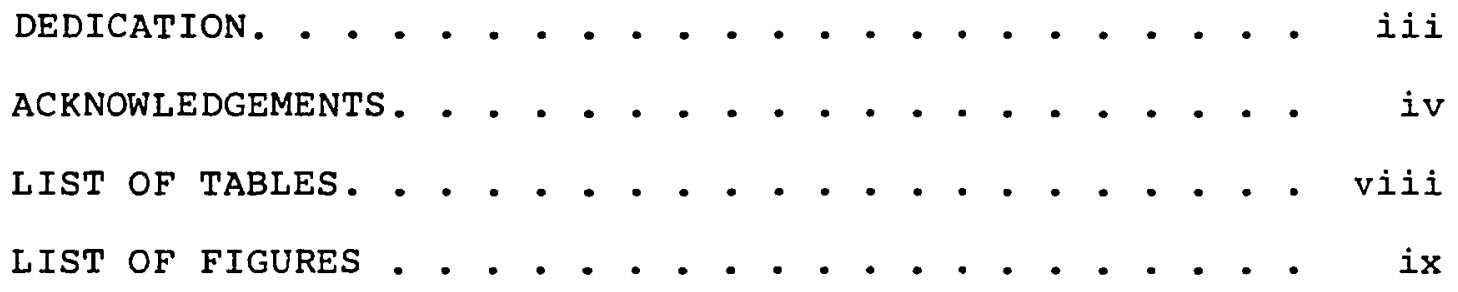

CHAPTER

I INTRODUCTION. . . . . . . . . . . . . . I

The Life Cycle and Morphology of

Closterium moniliferum. . . . . . . 5

The Trace Metal Copper . . . . . . . 11

Copper as a Toxicant/Nutrient

Copper Acting on the Life Cycle of

Adaptation of $\frac{\text { Closterium }}{\text { Organisms to copper }}$

Nitrogen Metabolism. . . . . . . . 18

Environmental Significance . . . . . . 21

Purpose of Research. . . . . . . . 24

II MATERIALS AND METHODS ............ 26

The Organisms. . . . . . . . . . 26

Environmental Conditions . . . . . . 27

Preparation of Glassware and Solutions . - 28

Copper Concentration and Speciation. . . 30

$\mathrm{pH}$ Measurement . . . . . . . . . 34 
Monitoring Cell Growth . . . . . . . .

Cell Counts

Cell Morphology

Sexual Reproduction

Determination of Cell Chlorophyll

Carbon Uptake as a Function of Copper

Nitrogen Uptake as a Function of

Copper Concentration. . . . . . . .

Long Term Nitrate Uptake and Growth

Short Term Nitrate Uptake

Long Term Ammonium Uptake and Growth

Measurement of Nitrate

Measurement of Ammonia

Determination of Nitrate Reductase

Activity

Photography. . . . . . . . . . . .

Light Microscopy

Scanning Electron Microscopy

Presentation of Data. . . . . . . 52

III INHIBITION OF GROWTH AND CELL DIVISION

BY EXCESS COPPER ............ 53

Introduction ........... . 53

Results and Discussion . . . . . . 54

Growth Patterns

Growth Rate

Cell Division and Morphology

Chlorophyll Content as a Function of Copper

${ }^{14}$ Carbon Uptake as a Function of Copper

Conclusion .......... . . 77

IV INHIBITION OF NITROGEN METABOLISM BY EXCESS

COPPER .................. 80

Introduction .. . . . . . . . 80

Results and Discussion . . . . . . . 81 


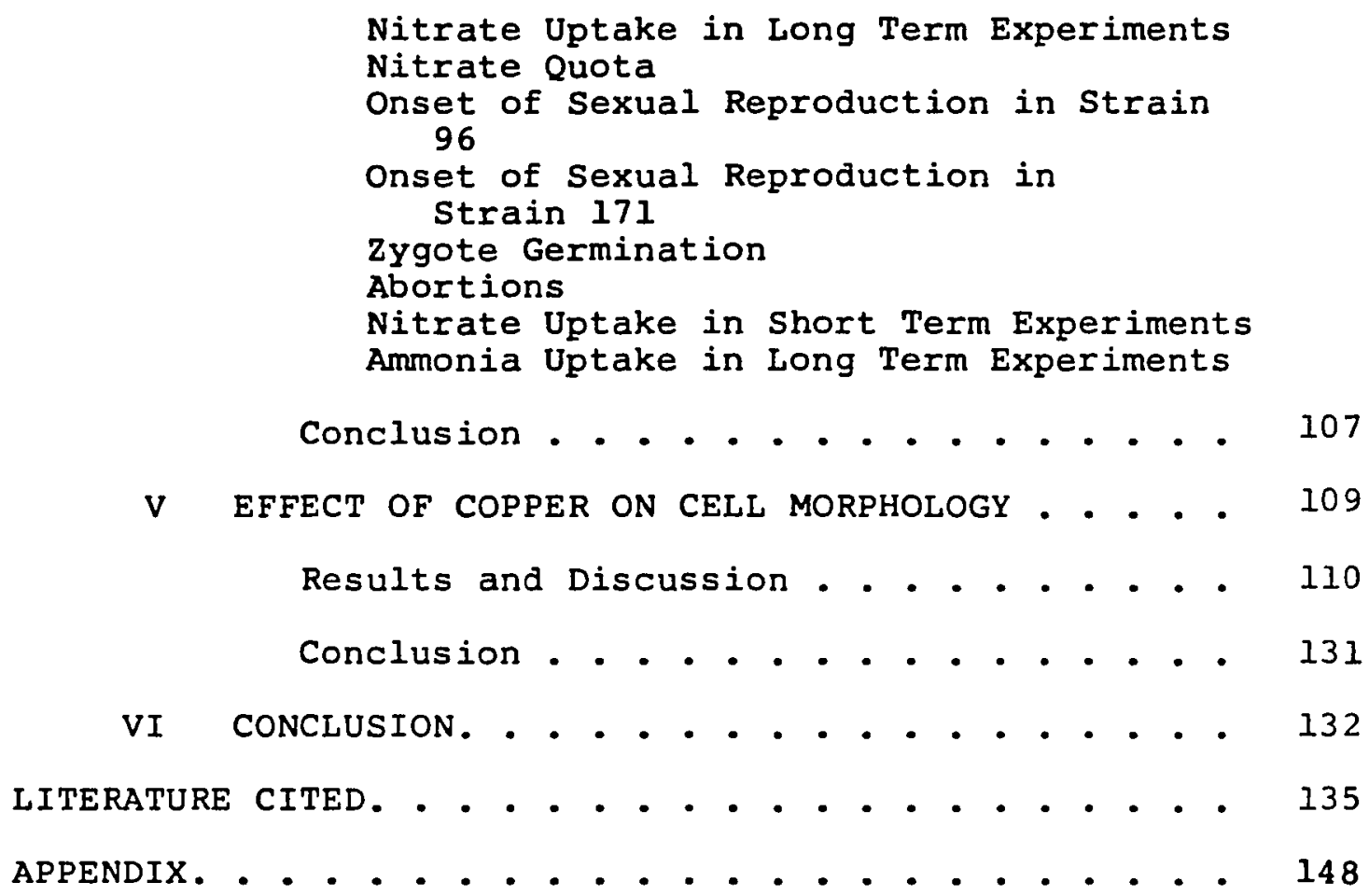




\section{LIST OF TABLES}

TABLE

PAGE

I Historical Trends in Global Copper Production and Release of Copper to the Atmosphere. . . 22

II Calculated Copper Activities in FRAQUIL with EDTA. . . . . . . . . . 32

II Specific Growth Rate. . . . . . . . . 65

IV Amount of Chlorophyll/Cell as a Function of $\mathrm{pCu}^{*}$................. 78

V Nitrogen Quota anc Onset of Sexual

Reproduction as a Function of Copper . . . 88

VI Onset of Sexual Reproduction as a Function of Beginning Nitrate... . . . . . 89

VII Percent Aberrant Cells. . . . . . . . . 92

VII Nitrate Uptake Rate . . . . . . . . 100

IX Nitrate Uptake Rate . . . . . . . . . 102

X Percent Aberrant Cells........... . 117 


\section{LIST OF FIGURES}

FIGURE

PAGE

1. Schematic Representation of the Effect

of Metal Ions on Physiological Processes . . 3

2. Suggested Sites of Action of Copper on

Nitrate Metabolism . . . . . . . . . 4

3. Diagram Showing Two Successive Divisions of

a Closterium Cell to Illustrate the

Distribution of the Parent Cell Walls to

the Daughter Cells . . . . . . . . . . 6

4. Mature Cell of Closterium moniliferum,

Strain \#96............... . . 7

5. Conjugation in Closterium: the $\underline{C}$. moniliferum-

ehrenbergii type . . . . . . . . . . . . 9

6. Type of Sexual Reproduction in Strain 171

(Homothallic) of closterium moniliferum

Resulting in the Production of Twin Zygotes. 10

7. Negative Log of Copper Concentration vs.

Calculated Copper Activity . . . . . . 33

8. Solubility Diagram of Copper . . . . . . . 35

9. Photomicrographs of Strain \#96 Without Copper

Treatment. . . . . . . . . . 37

10. Photomicrographs of Strain \#171 Without Copper

Treatment. • . • . . . . . . . . . 37 
11. Photomicrograph of Abnormal Cells of Strain \#96............. 38

12. Photomicrograph of Abnormal Cells of strain \#96............... 38

13. Photomicrograph of Strain \#96 that have not

Completed Cytokinesis. . . . . . . . 39

14. Photomicrograph of Strain \#96 that have not

Completed Cytokinesis. . . . . . . 39

15. Absorbance vs. Micromoles of Nitrate/Liter . . 46

16. Number of Cells per ml vs. Time (days) . . . . 55

17. Number of Cells per ml vs. Time. . . . . . . 56

18. Number of Cells per ml of Strain 171 vs. Time. - 58

19. Number of Cells per ml vs. Time (days) in

Strain 96 of Closterium moniliferum. . . . 59

20. Number of Cells per ml vs. Time (days) in duplicate cultures . . . . . . . . 60

21. Number of Cells vs. Time (days) in Strain 96

of Closterium moniliferum. . . . . . . 61

22. Number of Cells per $\mathrm{ml}$ at Day 7 vs. $\mathrm{pCu}$ *

in Strain 96 of Closterium moniliferum . . 62

23. Unseparated mature cells . . . . . . . . 67

24. Unseparated mature cells . . . . . . . . 67

25. Unseparated mature cells . . . . . . . . 68

26. Unseparated mature cells . . . . . . . . 68

27. Strain 96 of Closterium moniliferum. . . . . . 69 
28. Strain 96 of Closterium moniliferum. . . . . 70

29. Cells Treated with Copper. . . . . . . 71

30. Strain 96 of Closterium moniliferum. . . . . . 72

31. Strain 96 of Closterium moniliferum. . . . . . 74

32. Abnormal Cell of Closterium moniliferum. . . . 75

33. Strain 96 of Closterium moniliferum. . . . . 76

34. Strain 96 of Closterium moniliferum. . . . . 76

35. Nitrate Remaining in the Medium vs. Time (days). 83

36. Cell Number and Nitrate Uptake vs. Days. . . . 84

37. Number of Zygotes per Total Cell Number X 100 vs. Initial Concentration of Nitrate . . . 88

38. Percent Sexual Reproduction @ Day 15 of the Growth Curve vs. $\mathrm{pCu}^{\star}$. . . . . . . . 91

39. Strain 96 of closterium moniliferum. . . . . . 93

40. Strain 96 of Closterium moniliferum. . . . . . 93

41. Strain 96 of Closterium moniliferum Treated with Copper. . . . . . . . . . . 94

42. Strain 96 of Closterium moniliferum Treated with Copper. . . . . . . . . . . 94

43. Strain 96 of Closterium moniliferum. . . . . 95

44. Strain 96 of C\}osterium moniliferum. . . . . . 95

45. Nitrate Uptake Rate vs. Final Copper

Concentration. . . . . . . . . . . 99

46. Metabolic Sites that may be Blocked by the Action of Copper . . . . . . . . . 104 
47. Cell Number/mI vs. Time with Copper and Different Nitrogen Sources . . . . . 106

48. Typical Morphology Strain 96 of Closterium moniliferum. . . . . . . . . . . 111

49. Mature Symmetrical Healthy Cells of Strain 96 of Closterium moniliferum. . . . . . . . 112

50. Dynamic Focusing with the Scanning Electron Microscope . . . . . . . . . . . 113

51. Stereo Pair of Electron Micrographs of Strain 96 of Closterium moniliferum . . . . . . 114

52. Stereo Pair of Electron Micrographs of Strain 96 of Closterium moniliferum . . . . . . 114

53. Copper Treated Cell of Strain 96 of Closterium moniliferum. . . . . . . . . . . . 115

54. Enlargement of Rectangle in Figure 53. . . . . 115

55. Lysed Non-Viable Cell of Closterium moniliferum. . . . . . . . . . . . . 119

56. Lysed Non-Viable Cell of Closterium moniliferum. . . . . . . . . . . . . 119

57. Abnormal Cell of Strain 96 of Closterium moniliferum. . . . . . . . . . . . 120

58. Mucilage in Strain 96 of Closterium moniliferum. 121

59. Mucilage in Strain 96 of Closterium moniliferum. 121

60. Papillae in Strain 171 of Closterium moniliferum. . . . . . . . . . . . 122 
61. Strain 171 of Closterium moniliferum . . . . 123

62. Twin Zygotes of Strain 171 of Closterium moniliferum. . . . . . . . . . . . . 123

63. Twin Zygotes of Strain 171 of Closterium moniliferum. . . . . . . . . . . 124

64. Twin Zygotes of Strain 171 of Closterium moniliferum. . . . . . . . . . . . 124

65. Zygotes of Strain 171 of Closterium moniliferum. . . . . . . . . . . . 125

66. Zygotes of Strain 171 of Closterium moniliferum. . . . . . . . . . . . 125

67. Twin Zygotes of Strain 171 of Closterium moniliferum. . . . . . . . . . . 126

68. Twin Zygotes of Strain 171 of Closterium moniliferum. . . . . . . . . . . . . 126

69. Two Immature cells of Strain 96 of Closterium moniliferum Pairing Before Conjugation . • 127

70. Scanning Electron Micrograph of Zygote of Strain 96 of Closterium moniliferum. . . . 127

71. Zygotes of Strain 96 of Closterium moniliferum that are still Covered with the Mucilagenous Sheath from the Conjugation vesicle. . . . . . . . . . 128

72. Zygote of Strain 96 of Closterium moniliferum Without Mucilagenous Material. . . . . . 128 
73. Abortion in Strain 96 of Closterium moniliferum. 129

74. Abortion in Strain 96 of Closterium moniliferum. 129

75. Abortion in Strain 96 of Closterium moniliferum. 130

76. Enlargement of Cell in Upper Left of Figure 75 - 130 


\section{CHAPTER I}

\section{INTRODUCTION}

The purpose of this research was to determine the effects of copper as an agent of environmental stress on the life cycle of closterium moniliferum. The effects studied were cell division, sexual reproduction, zygote germination, and nutrient uptake.

Excess copper has been shown to have a toxic effect on growth and cell division (Sunda and Guillard, 1976; Anderson and Morel, 1978; Rueter, 1979; McKnight, 1981; and Petersen, 1982) and nutrient uptake (Rueter et al.. 1981) in algae. Dinoflagellates, diatoms, and some members of the Chlorophycophyta have been used in this recent research. Closterium moniliferum (Chlorophycophyta, Desmidiaceae) follows a more elaborate life cycle than other algae which have been studied. This allowed the additional dimension of the complete life cycle to be examined. As well as the previously studied aspects of growth, cell division, and nutrient uptake, onset of sexual reproduction and germination of zygotes were included.

Closterium moniliferum is a member of the group of the green algae (Desmidiaceae) which is commonly found in unpolluted, pristine bodies of water and is less common in polluted or nutrient enriched water. This may indicate 
that Closterium is an organism that is sensitive to excess pollutants, and it has been used in a rapid and reliable method for assessment of the trophic character of the plankton community (Thunmark, 1945). However, no critical studies of the specific response of this alga to metal ions have ever been conducted.

This alga offers a unique opportunity to study the effects of metal ions because of its elaborate life cycle. When exposed to metal ions, most cells show a typical doseresponse relationship. The presence of low concentrations will enhance a physiological process but at higher concentrations they become inhibitory and eventually toxic (Figure 1). This research included a study of the total life cycle of closterium, including sexual reproduction integrally tied to nutrient uptake and cell division in the presence of carefully selected concentrations of copper.

Growth of populations of Closterium moniliferum were monitored to correlate increase in cell number with uptake of nutrients. Desmids begin sexual reproduction when nitrogen amounts are low in the medium (Biebel, 1964), therefore, nitrogen was monitored in cultures with increasing amounts of copper. The results suggest that copper may be acting on the assimilatory nitrogen metabolism (Figure 2) of Closterium by acting on nitrate uptake and/or nitrate reduction. The timing of sexual reproduction should be affected by copper: if nitrate uptake were stimulated, sexual 


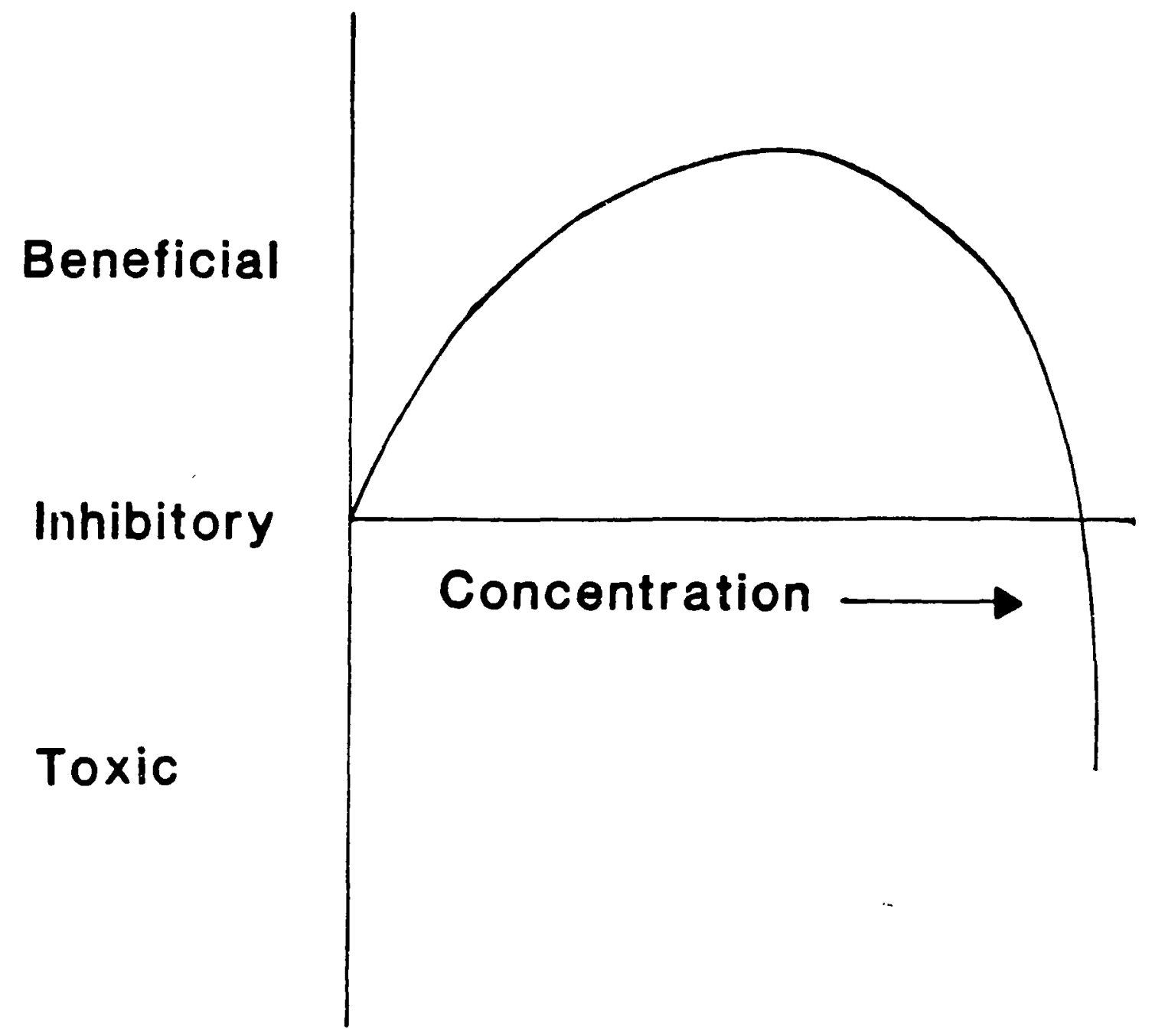

Fiqure 2. Schematic representation of the effect of metal ions on physiological processes. These are frequently beneficial but become inhibitory and toxic at higher concentrations (based on Fraústo da Silva and williams, 1976). 


\section{Cell membrane}

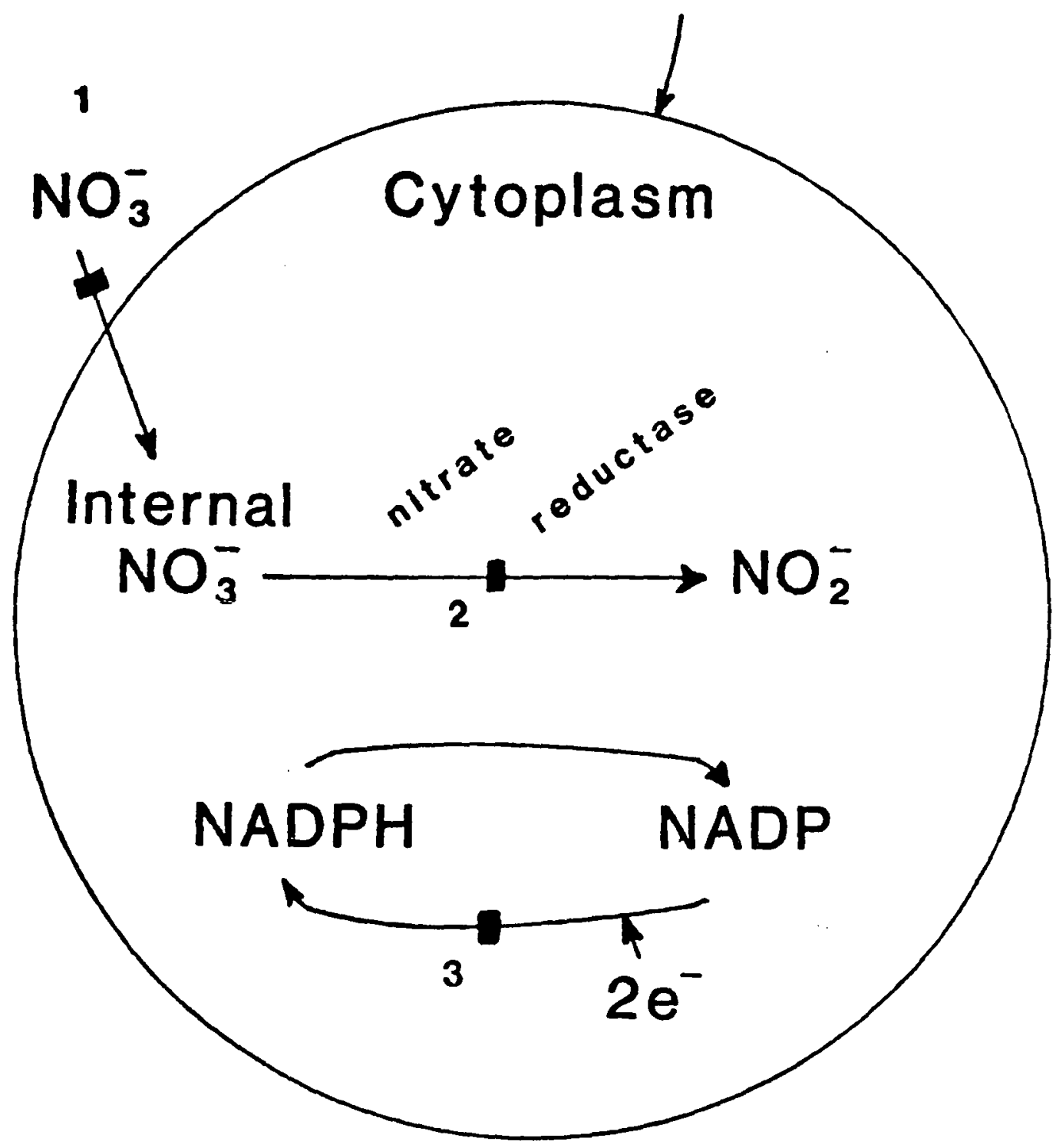

Figure 2. Suggested sites of action of copper $\left(\mathrm{Cu}^{2+}\right)$ on nitrate metabolism. The numbers 1, 2, 3 indicate specific sites where inhibition may be occurring:

1) Copper inhibits nitrate uptake;

2) Copper inhibits nitrate reduction by acting on the enzyme nitrate reductase:

$3)$ Copper inhibits nitrate reduction by interferring with NAD (P) reduction. 
reproduction would occur earlier; if nitrate uptake were inhibited, sexual reproduction would be delayed.

Besides the requirement for nitrogen depletion in the environment before sexual reproduction can occur, the vegetative cells must divide. Light microscopy and scanning electron microscopy were used to monitor quantitative and qualitative changes in cell morphology of dividing cells. The morphological studies add additional information to the growth studies and may provide a key to the inhibition of cell division exemplified by the increased lag phase. Inhibition of nitrate uptake by copper parallels the inhibition of cell division: Because the nitrogen requirements of closterium moniliferum are integrally tied to its sexual reproduction, it is seen that copper can be an effective tool in understanding the total life.cycle of this alga.

THE LIFE CYCLE AND MORPHOLOGY OF CLOSTERIUM MONILIFERUM

The cells of Closterium moniliferum are elongate unicells, narrowed toward both poles, sometimes slightly tumid at the equator and slightly arcuate. A central nucleus lies between the two chloroplasts at the equator of the cell. After division, a cell has one semi-cell of the parent cell wall and one semi-cell which is formed by new cell wall secretions (Figure 3 ). When mature, the cells are symmetrical with both semi-cells of the same size (Figure 4). 


\section{Cell Division}

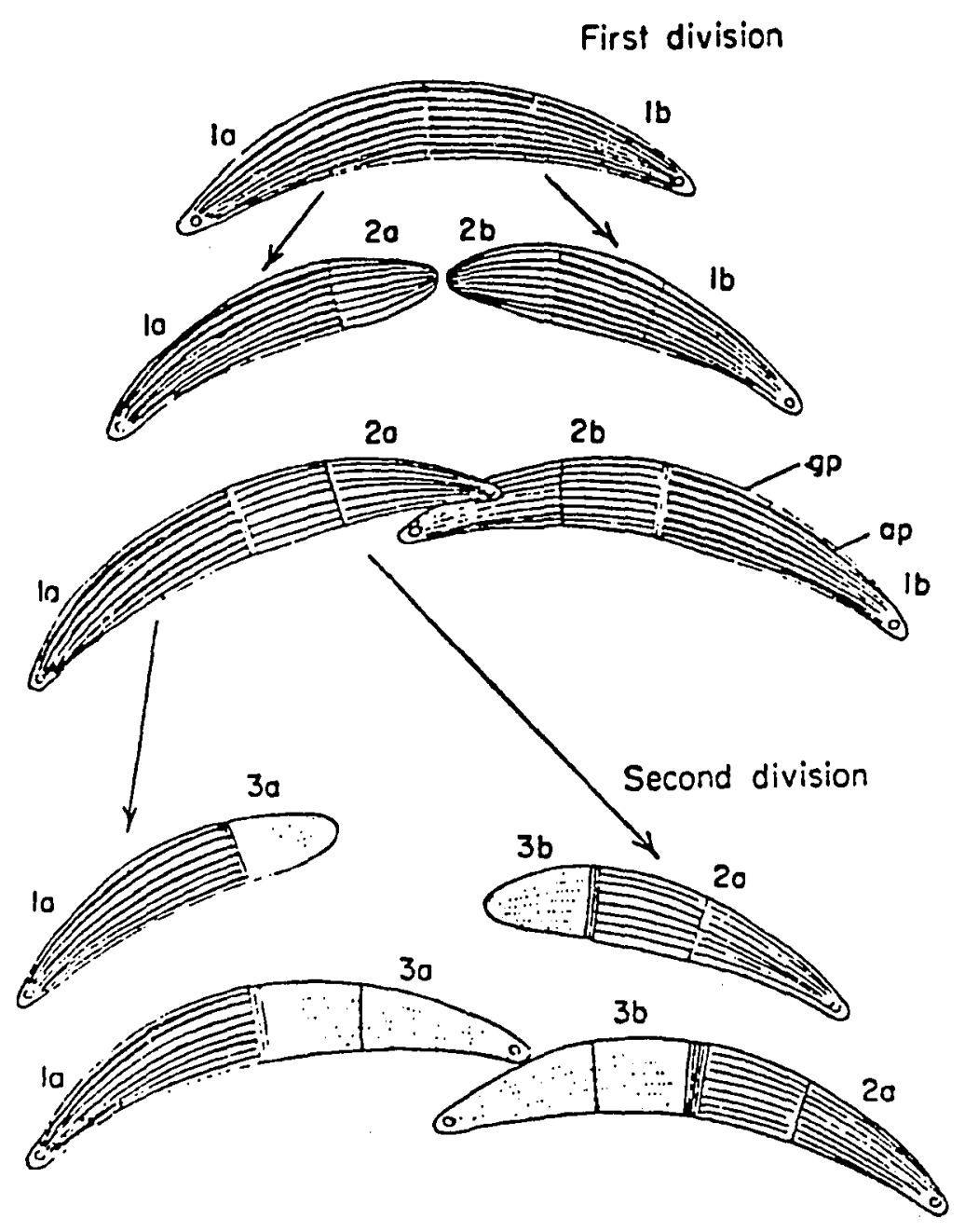

Figure 3. Diagram showing two successive divisions of a closterium cell to illustrate the distribution of the parent cell walls to the daughter cells. The walls of the lst generation cell (la and lb) are drawn with heavy longitudinal striations; those of the 2nd generation ( $2 a$ and $2 b$ ) with lighter striations; while those of the $3 r d$ generation ( $3 a$ and $3 b$ ) have striations shown as dotted lines. $g p=$ girdle portion; ap = apical portion (Brook, 1981). 


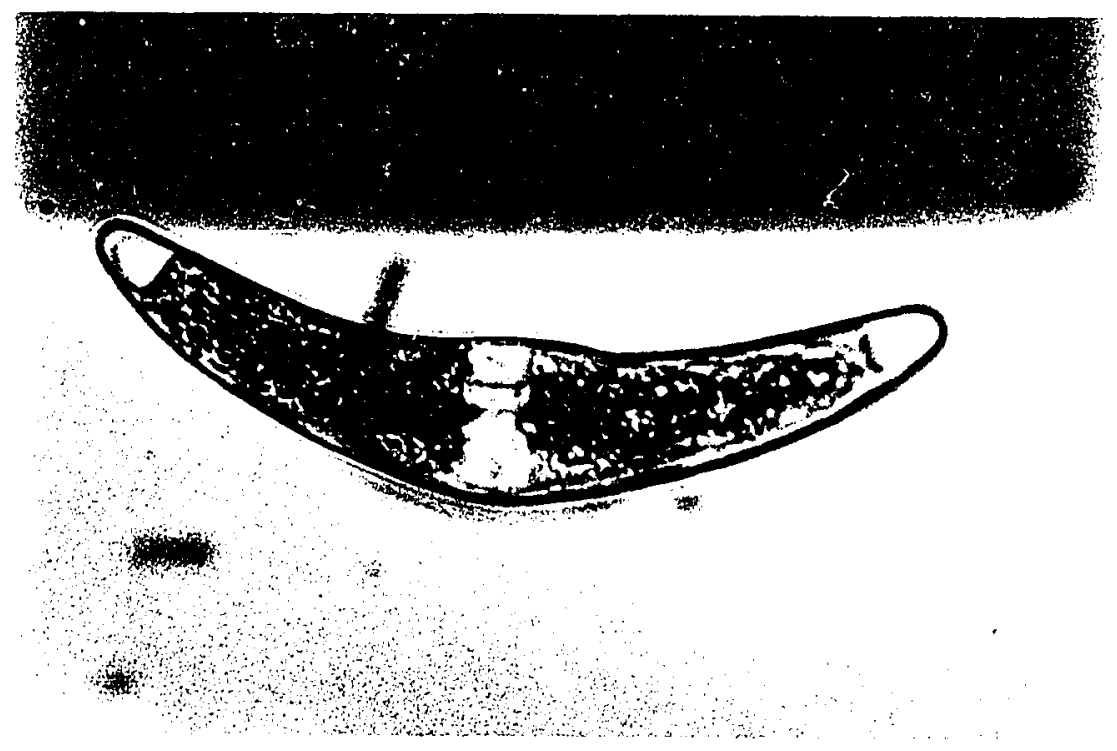

Figure 4. Mature cell of closterium moniliferum, strain \#96. $430 \mathrm{X}$. 
The cells themselves act as gametes when light is present (Ueno and Sasaki, 1978; Hogetsu and Yokoyama, 1979 ) and when certain physiological conditions, such as low nitrogen concentrations, exist (Biebel, 1964). The cells divide and the immature daughter cells mate to form a single zygote in one homothallic strain (\#96, Figure 5) or twin zygotes in another homothallic strain (\#171, Figure 6). Sexual reproduction occurs before the newly divided cells attain the symmetry characteristic of mature cells, a trait first observed in Closterium moniliferum by Fox (1957) and further elucidated by Lippert (1967). The cell contents from two cells travel through a conjugation tube and fuse to form a zygote, which is the only diploid stage in the life cycle.

Zygotes require a maturation time of $1-2$ months in the dark (Lippert, 1967). Mature zygotes will germinate when they are exposed to light and are supplied with nutrients and moisture. These new cells, released from the germinating zygotes, begin a new life cycle and can reproduce sexually or vegetatively, depending on conditions of growth. In strain 96 , sexual reproduction begins when low nitrogen concentrations exist. This phenomenon was chosen as a point of interest in the overall hypothesis of this research. The interrelationship of nitrogen and copper could influence the total life cycle (e.g. delaying sexual reproduction, inhibiting nitrogen assimilation and/or inhibiting cell division). 


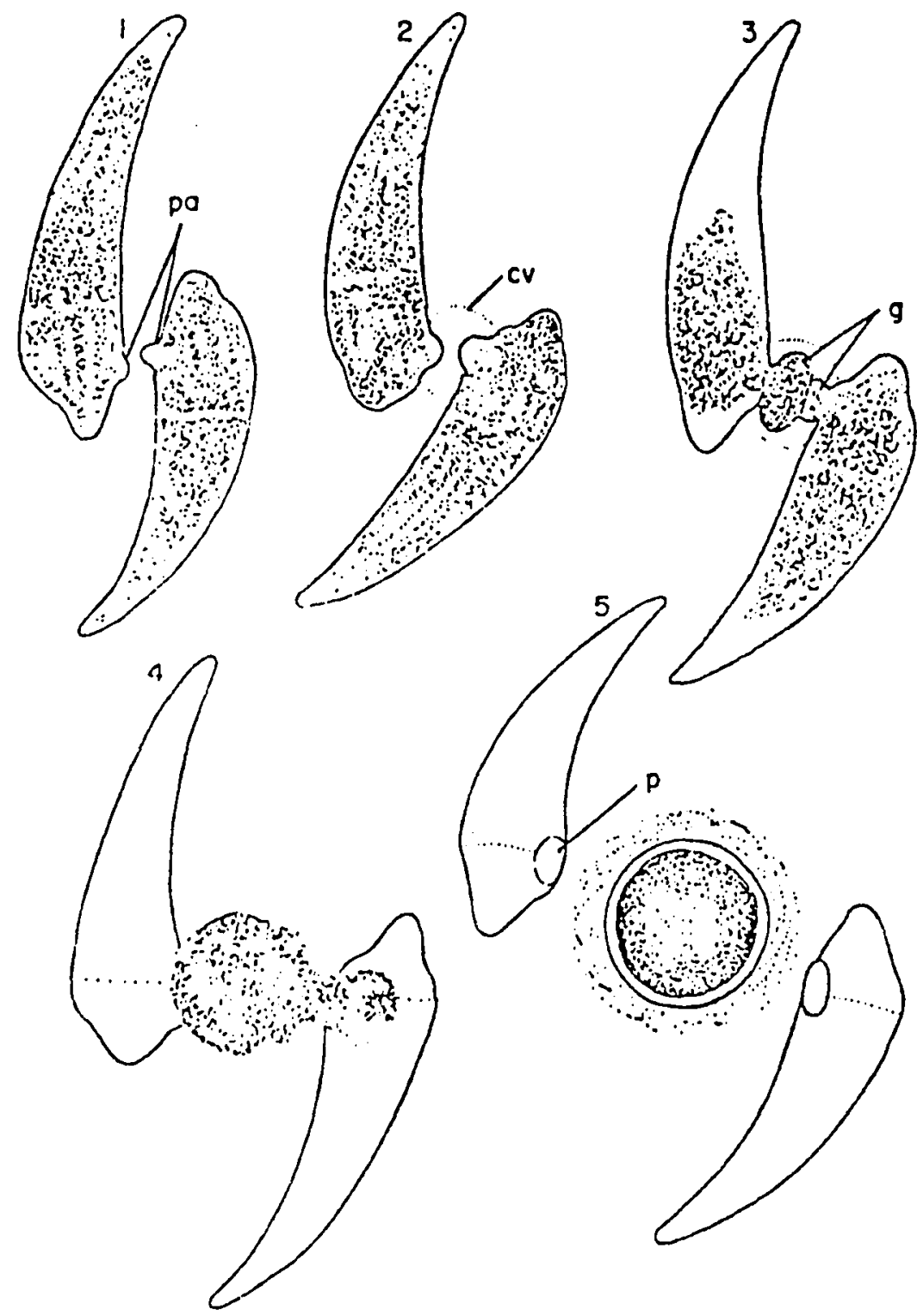

Figure 5. Conjugation in Closterium: the C. moniliferum-ehrenbergii type. 1) The pairing of immature daughter cells and formation of conjugation papillae; 2) Secretion of hyaline conjugation vesicle;

3) Initiation of movement of gametes; 4) Final stages of gamete fusion; 5) Mature zygospore and empty cells showing conjugation pore.

$\mathrm{cv}=$ conjugation vesicle; $\mathrm{g}=$ gametes; $\mathrm{p}=$ conjugation pore; pa = papillae (Brook, 1981). 

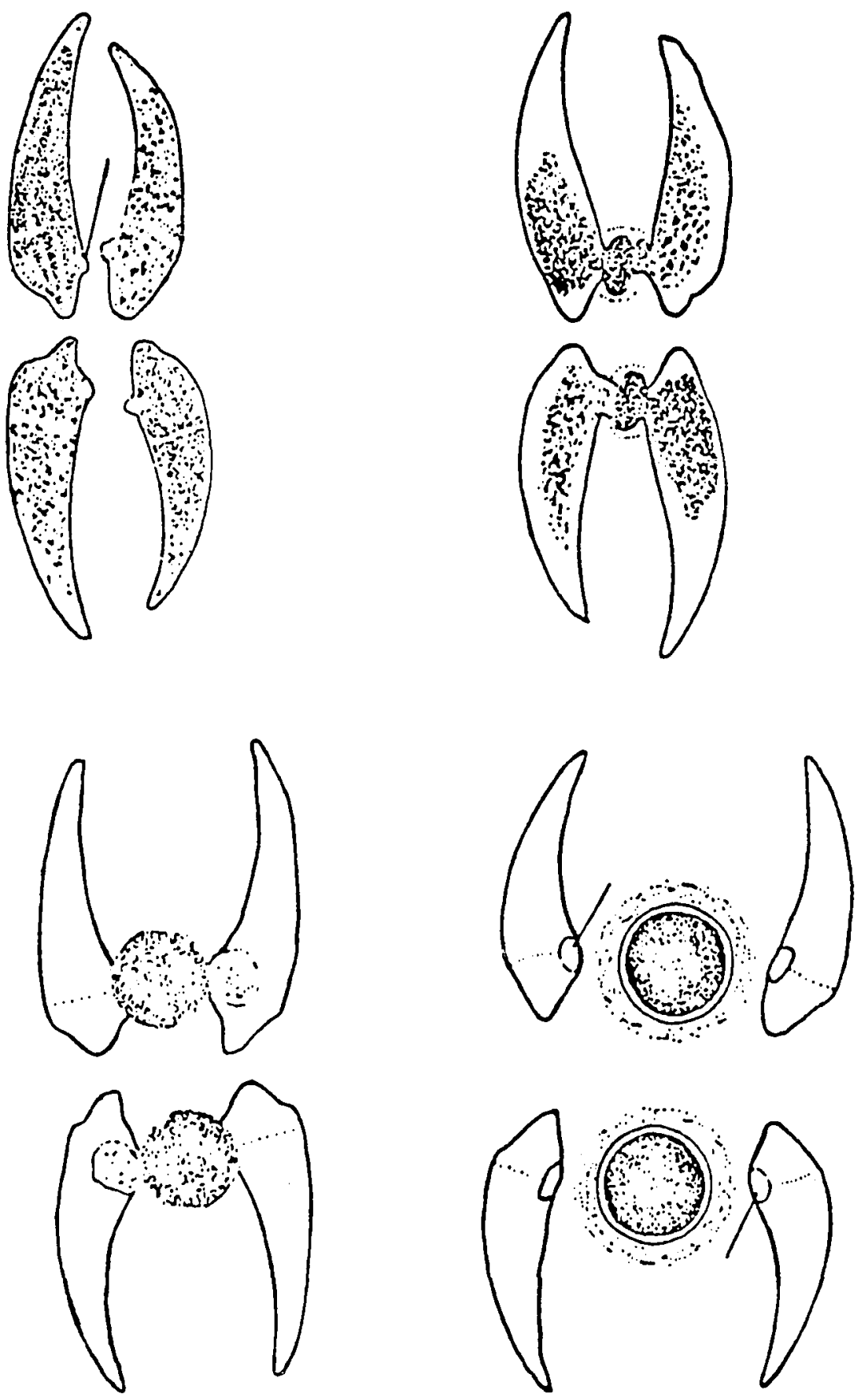

Figure 6. Type of sexual reproduction in strain 171 (homothallic) of Closterium moniliferum resulting in the production of twin zygotes. 
THE TRACE METAL COPPER

Copper is a required micronutrient (Price, 1970) yet is one of the trace metals that is most toxic to phyto-plankton (Hollibaugh et al., 1980). Its toxic effect is in large part due to its affinity for sulfhydryl groups and its ability to displace metal ion cofactors or active metal centers from metal dependent enzymes (Passow et al., 1961). The action of copper on the sulfhydryl groups may inactivate physiologically crucial sH-dependent enzymes or alter their catalytic specificity or control. Reaction of copper with side chains or replacement of other metals may result in a change in the electrostatic charge and a shift in the ionization constant of the active center to give a change in catalytic ability (Passow et al., 1961).

Mandelli (1969) suggested that copper is strongly bound in carboxyl, phosphate, amino, or sulthydryl groups and thus its effect tends to be non-specific. Other evidence suggests, however, that copper may act more specifically on the SH groups. For example, Gurd and Wilcox (1956) found that copper oxidized SH groups forming S-S bridges and Fisher and Jones (1981) suggested a common action on SH groups for $\mathrm{Hg}, \mathrm{Cu}, \mathrm{Zn}, \mathrm{Pb}, \mathrm{Cd}$, and $\mathrm{Mn}$ by showing the relative toxicities of the metals are correlated ( $r=0.961)$ with the solubility products of the correlated metal sulfides. While copper does show specificity towards SH groups, sensitive SH groups are so ubiquitous and of importance to so 
many different enzymes, that sites of action within a cell are multiple.

The addition of sulfhydryl reactants affects cell division. Hughes in 1950 reported that sulfhydryl reactants in general could block cells from entering prophase and Dustin had earlier (1947) suggested that mitotic poisons were enzyme inhibitors. Stern (1956) found that sulfhydryl groups were important in regulating plant cell division in developing anthers of the lily. Kanazawa and Kanazawa (1969) found that nuclear division in copper treated Chlorella cells was completed but cellular division did not occur. They assumed that the process suppressed by copper was probably concerned with some events related to the cell membrane rather than with those occurring inside the cell. It is probable that both events occur, with the membrane showing the primary effect since it is the location of first contact with the metal.

Evidence indicates that the membrane may include sites of action for metals. Rothstein (1959) saw a rapid reversibility of some of the effects of metal toxicity indicating the membrane as one target. Although photosynthesis inhibition and potassium excretion induced by copper and mercury followed similar dose-response curves in the green alga Chlorella pyrenoidosa, Kamp-Nielsen (1971) concluded that the primary effect of bound metals (copper and mercury) was to cause some destruction of a diffusion barrier causing an out-flow of potassion. Overnell (1975), working 
with dinoflagellates, found results consistent with the suggestion of McBrien and Hassall (1965) working with Chlorella, that the primary toxic effect of copper is to increase the permeability of the cell. He reported that with $\mathrm{Cu}^{2+}, \mathrm{K}^{+}$release occurred at a marginally lower concentration than did inhibition of photosynthesis. The action of copper on permeability has not been confirmed since the work of defilippis (1979) showed little effect on potassium loss from Chlorella.

Using isolated chloroplasts, Cedeno-Maldonado et al-(1972)

found that copper affected the photosynthetic process itself. Shioi et al. (1978 a and b) showed that copper inactivated the electron transport of photosystem II and Haberman (1969) showed that both the Hill and Mehler reactions were inhibited by copper.

\section{Copper As A Toxicant/Nutrient}

Since the investigations of Moore and Kellerman (1904) copper has been used extensively as an algicide in algal control programs. It has recently been established that the total amount of copper in natural waters is not the crucial factor in toxicity to organisms; rather, it is the speciation (chemical form) of copper and the equilibration of those species in the environment/medium that determines the activity and toxicity of ionic copper (Sunda and Guillard, 1976; Anderson and Morel, 1978; Jackson and Morgan, 1978; Rueter et al.., 1979; and Sunda and Gillespie, 1979). 
Different organisms respond to the activity of ionic copper with different sensitivities; the levels where copper is toxic varies (Erickson et al., 1972).

Because the biological response is dependent on free ion activities, the effect of chelators is very important. In the laboratory, Anderson and Morel (1978) found that pre-equilibration for 24 hours with the metal chelator, EDTA, was necessary to prevent a dramatic overestimate of copper sensitivity of the organisms. Sunda et al. (1981) found stimulation of pinytoplankton growth by organic chelators (EDTA and NTA) appeared to result directly from the ability of these chelators to tightly complex copper without appreciably binding manganese. Fitzgerald and Faust (1963) reported that EDTA decreased algicidal effects of copper on an equivalent basis as naturally occurring metal complexing agents. Upwelling water is likely to have copper present in ionic and thus toxic form (Steemann Nielsen and Kamp-Nielsen, 1970). Sampling from upwelling seawater has shown that an emerging biological community may produce natural chelators which may act to increase phytoplankton growth similar to EDTA and NTA additions (Martin, 1967; Barber and Ryther, 1969; Murphy et al.. 1976; and Van der Berg et al., 1979).

The effects of copper toxicity can be partially or completely reversed by appropriate iron, manganese, or chelator additions (Haberman, 1969; Gross et al.. 1970; and Sunda et al., 1981). With the aid of thermodynamic 
calculations, sunda et al. interpreted the results as a physiological interaction between copper and manganese in which copper competes for manganese nutritional sites, thereby interfering with manganese metabolism. Experimental results of Braek et al. (1976) with copper, zinc, and manganese indicate a common route for divalent metal ions in Phaeodactylum tricornutum. Anderson and Morel (1978), however, did not find the results of copper sensitivity altered with manganese concentrations varied over two orders of magnitude. In some cases, there is a synergistic effect between two metals (copper and silver) to produce greater toxicity (Young and Lisk, 1972) although Petersen (1982) found no clear evidence of interaction between copper ion and $z$ inc ion in producing toxicity.

It seems quite certain that the essentiality of copper to algae arises from its role as a prosthetic group in a number of vital enzymes and proteins, for example, being a component of the molecule plastocyanin of photosynthesis. Its ability to function depends on its intrinsic favorable chemical properties, including the ease of changing its oxidation state. As a transition metal, it has the capacity to complex effectively with a variety of proteins and porphyrins (Frieden, 1981) and with substances that are metal chelators.

Besides being a required nutrient for algae (Myers, 1962: Manahan and Smith, 1973), Rothstein (1959) suggests 
a beneficial effect of copper in protecting active sites. Sato (1980) found that copper could bind with toxic compounds to return activity to the enzyme phenolase in spinach chloroplasts. Oxalate, usually toxic, acted as a chelator with the copper.

Copper Acting on the Life Cycle of Closterium moniliferum Copper may act on the amount of nitrogen available to Closterium moniliferum and could be a factor in inducing sexual reproduction. Depleted nitrogen has been found to induce sexual reproduction in desmids (Biebel, 1964), and copper has been shown to inhibit nitrate uptake in some organisms (Harrison et al., 1977). Sexual reproduction may be tuned to environmental patterns and may be a mechanism of survival at a time of physiological stress. Although the organisms may reproduce by vegetative cell division only, it may be advantageous, when in the presence of added copper, to begin a different stage in the life cycle. Zygotes are thick walled and should be less susceptible to increases in metal concentration. This research showed that copper acted on the assimilatory process of nitrate uptake and was able to influence the onset of sexual reproduction.

\section{Adaptation of Organisms to Copper}

An organism must contend with the problem of maintaining a minimal internal concentration of copper sufficient to meet its needs, but, at the same time, prevent the 
occurrence of a toxic level of the metal. Genetic selection for higher tolerance has occurred in some algae (Russell and Morris, 1970; Foy and Guloff, 1972; and Stokes et al., 1973). Potential tolerance mechanisms for copper and algae include exclusion, extracellular binding, precipitation on the outside of the cell membrane, utilization of noisensitive intracellular sites, and metabolic shunts (Stokes, 1979).

Secretion of algal exudates may ameliorate copper toxicity by extracellular binding (Swallow et al., 1978 and Van der Berg et al., 1979) or changes in $\mathrm{pH}$ which would change the solubility and subsequently the toxicity of copper (Foy and Gerloff, 1972).

Exclusion of copper (Foster, 1977; Hall et al., 1979) or differential uptake of copper ions (Jensen et al., 1976; Bentley-Mowat and Reid, 1977; Bowen and Gunatilaka, 1977; and Hogan and Rauser, 1981) have also been suggested as mechanisms for copper tolerance.

There is increasing evidence in higher plants and fungi (Neurospora and Saccharomyces) that copper tolerance appears to be due in part to the presence of specific heavy metal binding proteins, metallothioneins (Rauser and Curvetto, 1980). These may act as depots for heavy metals and in addition, serve to bind, and thus sequester, the toxic metal (Lerch, 1981). Stokes et al. (1977) extracted a low-molecular-weight ( 8000 daltons) copper-binding protein from the cytosol of a copper-tolerant Scenedesmus. The 
amount of this protein increased in response to increased copper in the medium. In 1977 Nakajima et al. described a low-molecular-weight copper-binding compound from the cells of Chlorella regularis. Of the soluble intracellular copper, $49 \%$ was bound to two identifiable protein fractions. These copper metallothioneins may play a role in copper metabolism in absorption, transport, storage, and excretion of the metal.

NITROGEN METABOLISM

Nitrogen metabolism is integrally tied to the cell cycle of Closterium. Because nitrogen depletion in the environment induces sexual reproduction (Biebel, 1964; Ichimura, 1971), the effect of copper on nitrogen metabolism, and in particular nitrogen uptake, is of great importance. Nitrate uptake kinetics depend on the species of algae, the concentration of nitrate in the environment and on the nitrogen cell quota (Eppley et al., 1969; Eppley and Renger, 1974). Nitrate is transported into the cell and is very rapidly assimilated by being reduced to nitrite with further reduction occurring to produce ammonia, which is then incorporated into amino acids (Lehninger, 1975).

Because of the requirement for an 8 -electron reduction, the most generally accepted sequence for nitrate reduction was long believed to be:

$$
\mathrm{NO}_{3} \rightarrow \mathrm{NO}_{2}-\mathrm{N}_{2} \mathrm{O}_{2} \rightarrow \mathrm{NH}_{2} \mathrm{OH} \rightarrow \mathrm{NH}_{3} \text { (Syrett, 1962). }
$$


However, more recent work with algae (zumft et al., 1969; Aparicio et al., 1971) suggests that only two enzymes catalyze the entire reduction of nitrate to ammonia. The first enzyme is nitrate reductase (NAD(P)H:nitrate oxidoreductase) which catalyzes the reduction of nitrate to nitrite. This enzyme is a pyridine nucleotide-linked molybdoflavoprotein. The electrons are transferred from NAD $(P) H$ to FAD, molybdenum being a required co-factor. The second enzyme is nitrite reductase (NAD(P)H:nitrite oxidoreductase) which catalyzes the reduction of nitrite to ammonia.

Nitrate reductase is believed to be readily accessible in unicellular organisms and nitrate uptake is considered to be closely correlated with nitrite assimilation. In most organisms, the enzyme is not constitutive and synthesis appears to be induced within a few hours when nitrate concentrations are increased in the medium (Harrison et al., 1977). Most algae will preferentially take up reduced forms of nitrogen such as ammonia or urea rather than nitrate. The suppression of nitrate uptake by ammonium has been reported for natural populations (MacIsaac and Dugdale, 1969, 1972) and for laboratory cultures with Chlorella (Morris and Syrett, 1963; Syrett and Morris, 1963; Grant and Turner, 1969) and with marine phytoplankton (McCarthy and Eppley, 1972). Their work points to substantial suppression of nitrate uptake until ammonia falls below 1 microgram-atom/liter. It is believed that the end 
products such as ammonia and amino acids are inhibiting the synthesis or the activity of nitrate reductase (syrett, 1981).

In contrast, however, Harrison (1973), working with Peridinium and other dinoflagellates and diatoms from a bloom, and Topinka (1978), working with Fucus, found that under saturating nutrient conditions nitrate is utilized at significant rates even in the presence of high levels of ammonia. Bienfang (1975) argues that under nutrientlimiting conditions, with Dunaliella, the ambient ammonia never reaches concentrations high enough to inhibit an induced nitrate-utilization system. No information on use of nitrogen sources in Closterium has been reported.

Nitrate reductase can undergo rapid changes in activity as a consequence of oxidation-reduction reactions in response to the ongoing metabolism in the cell (Hewitt, 1975). Copper has been found to inhibit the activity of nitrate reductase and the uptake of nitrate (Harrison et al.. 1977). Shioi et al. (1978b), from their work with Ankistrodesmus, suggest that this may occur because copper inactivates the electron transport of photosystem II and there is not an adequate supply of reductants for nitrate reduction.

Previous work has demonstrated that copper does decrease photosynthesis and chlorophyll content in Chlorella (MCBrien and Hassall, 1965); Steemann Nielsen et al.. 1969; Rosko and Rachlin, 1977) and in Dunaliella and Phaeodactylum (Overnell, 1975). In Chlorella, Hassal (1963) showed that 
photosynthesis was more sensitive to copper additions than was the specific growth rate. No previous work had been done on copper's effects on Closterium.

Closterium is a slower growing organism than many unicellular algae and is not commonly used as a research organism. It has been used in this research because of its metabolic trigger for sexual reproduction. Whether copper directly affects nitrogen availability or indirectly affects photosynthesis, chlorophyll production, or cell division is a complex question. If the effect is mainly on nitrogen metabolism, copper as an environmental pollutant is particularly significant in the life cycle of $\cdots$ Closterium moniliferum.

ENVIRONMENTAL SIGNIFICANCE

Since Closterium has been used as an indicator organism, the information on copper's effect gained in the laboratory may be helpful in assessing natural populations.

Copper is one of the chemicals that man cycles more rapidly than nature. The recycling of copper occurs at a ratio of $12: 1\left(4460 \times 10^{3}\right.$ metric tons man-induced rate: $375 \times 10^{3}$ metric tons geological rate) (Ketchum, 1972). Anthropogenic effects can be noted in the significant increase this century in the level of copper production and release of copper to the atmosphere (Table I). The level of copper in natural waters is approximately $10^{-7} \mathrm{M}$ or less 
TABLE I

HISTORICAL TRENDS IN GLOBAL COPPER PRODUCTION

AND RELEASE OF COPPER TO THE ATMOSPHERE

\begin{tabular}{|c|c|c|}
\hline Period & $\begin{array}{c}\text { Copper } \\
\text { Production } \\
\text { Consumption } \\
\left(x 10^{12} \mathrm{~g}\right)\end{array}$ & $\begin{array}{l}\text { Atmosphere } \\
\text { Copper Emission } \\
\left(\mathrm{x} 10^{10} \mathrm{~g}\right)\end{array}$ \\
\hline Pre-1900 & 58 & 41.1 \\
\hline $1900-1910$ & 7.5 & 5.3 \\
\hline $1910-1920$ & 11.3 & 8.0 \\
\hline $1920-1930$ & 13.5 & 9.6 \\
\hline $1930-1940$ & 16.3 & 11.7 \\
\hline $1940-1950$ & 23.8 & 17.0 \\
\hline $1950-1960$ & 32.4 & 23.0 \\
\hline $1960-1970$ & 61.4 & 43.5 \\
\hline $1970-1980$ & 82.5 & 58.5 \\
\hline $1980-1990$ & 136 & $\underline{97.4}$ \\
\hline Total, 3800 B.C.-A.D. 1980 & 307 & 315 \\
\hline
\end{tabular}

(from Nriagu, 1979) 
(6. 4 microgram/1 or less) (Bentley-Mowat and Reid, $1977)$.

One of the effects of copper additions to natural waters is decreased growth and species shifts in the natural community. Sunda et al. (1981) showed a shift from diatoms to green flagellates and Thomas and Seibert (1977) showed a decrease in the proportion of centric diatoms and dinoflagellates.

Some algae have been known to react to nonoptimal environmental conditions by beginning a different stage in their life cycles. An example of the effect of nonoptimal environmental conditions is the resting spore formed by Leptocylindrus denicus when nitrate level was reduced below 0.5 micromoles in CEPEX experiments (Davis et al., 1980). Under conditions of copper stress, the marine dinoflagellate Gonyaulax tamarensis was found to become immotile with no increase in size or cell division (Anderson and Morel, 1978). These cells were termed a "temporary resting stage in the life cycle" which could be revived if the stress due to copper had not been too severe and normal culture conditions were restored.

This thesis shows that a different series of events occurs with the life cycle of Closterium moniliferum. The zygotes produced in the presence of copper do not differ from the zygotes produced without additional copper present. Copper does not affect the germination of the zygotes, which 
are surrounded by a thick layered cell wall. Rather, copper stress is significant in the life cycle in the time of onset of sexual reproduction. The occurrence of earlier sexual reproduction as a result of added copper may allow the organisms to survive pulses of toxicants in the environment by reducing the amount of time the cells spend in the vegetative state. This may, however, reduce the utility of Closterium moniliferum as an indicator organism of unpolluted waters.

\section{PURPOSE OF THE RESEARCH}

The purpose of this research was to study the sensitivity of the life cycle of closterium moniliferum to copper. Closterium has an elaborate life cycle which is dependent on environmental changes. Environmental changes for this study were effected by adding copper or by using different sources of nitrogen in the medium.

The parameters of the life cycle that were measured were increase in cell number, onset of sexual reproduction, zygote germination, and uptake of nitrogen. The effect that copper had on each of these parameters was the essence of this research.

Cell division is always critical in a population but it is especially critical here since the process of cell division must occur before sexual reproduction and is therefore closely tied to that stage in the life cycle.

The uptake of the nutrient nitrogen is also closely tied to sexual reproduction; depletion of nitrogen in the 
medium, in the form of nitrate, appears to be a trigger for sexual reproduction. A stimulatory or inhibitory response of nitrate uptake or of cell division could alter the timing of the life cycle.

The ultimate question, then, is if the timing of the Iife cycle can be changed by copper additions in the environment, can this lead to survival of closterium in natural waters by production of resistant zygotes? The success of this laboratory study may give direction to field studies in which phytoplankton are able to survive pulses of toxicants in natural waters. 


\section{CHAPTER II}

\section{MATERIALS AND METHODS}

\section{THE ORGANISMS}

The organisms used in this study were strains 96 and 171 of Closterium moniliferum from the Portland state University algal culture collection. Both strains are presently stored in the Culture Collection of Algae at the University of Texas (Starr, 1978). Strain 96 was used for all experiments; both strains were used for the scanning electron microscopy work to compare morphology and for the long term growth/uptake experiments to compare the time of onset of sexual reproduction.

\section{Strain 96}

Strain 96 is a homothallic strain that produces a single zygote in sexual reproduction. It was originally isolated by B.E. Iippert from a soil sample collected by Melvin Goldstein from a marshy area near Shulman's Equipment Co. Rt. 46 in New Jersey on August 21, 1959. The average size of a mature cell of strain 96 is 29 micrometers $x$ 147 micrometers; zygote measurement is $45 \times 45$ micrometers. It is stored in algal culture at the University of Texas at Austin as LB 2302 Closterium moniliferum (Bory) Ehr. 
Strain 171

Strain 171 is a homothallic strain that produces twin zygotes in sexual reproduction. It was originally isolated and collected by B.E. Lippert from a farm pond, 2 miles south of a sewage disposal plant, on Fern Hill Road, south of Forest Grove, Oregon in August, 1959. The average size of a mature cell of strain 171 is 43 micrometers $x 214$ micrometers; zygote measurement is $48 \times 54$ micrometers. It is stored in algal culture at the University of Texas at Austin as LB 2303 Closterium moniliferum (Bory) Ehr.

\section{ENVIRONMENTAL CONDITIONS}

Cultures were grown at $21^{\circ} \mathrm{C}$ in an Environator under continucus light (cool-white fluorescent) of 4000 lux measured with a GE Triple Range 214 Light Meter. Since Whitton (1968) reported that toxicity of metals, particularly copper, was decreased by light, the cultures were grown in continuous light to eliminate the variable of light/dark cycles. Cultures were manually swirled every 24 hours to facilitate the availability of nutrients to all cells and to prevent the cells from adhering continuously to the glass containers. Fitzgerzld (1975) found that continuous shaking of cultures of Scenedesmus resulted in no improved maximum rates of growth as long as relatively low volumes of liquid per flask were used. Also, Bentley-Mowat and Reid (1977) reported that there was not much difference in sensitivity 
of species to copper in batch cultures as compared with continuous culture.

PREPARATION OF GLASSWARE AND SOLUTIONS

\section{Glassware}

Glassware used for all experimental work was washed in $95 \%$ dodecyl sodium sulfate, rinsed 5 times in tap water, and put in an acid wash of $10 \% \mathrm{HCl}$ solution for 24 hours. After the acid wash, the glassware was rinsed 5 times with tap water and 5 times with deionized water from a sybron/ Barnstead system (nanopure water). After air drying, the glassware was covered with parafilm for storage.

Medium

The organisms were grown in batch cultures in the defined medium FRAQUIL (Morel et al., 1979). (See Appendix for quantities of components and method of preparation.) The water used in the medium (and in all solutions) was nanopure deionized water from a Sybron/Barnstead system. A supplement to FRAQUIL is a vitamin solution, including thiamine HCl, biotin, and B-12. Preliminary work demonstrated that there was no significant increase in growth or zygote production with the vitamins present so vitamins were not added to the growth medium for experimental work. The lack of a vitamin requirement may have been due to the fact that cultures were not continually axenic and the bacteria were supplying the growth factors. Cells were periodically 
reisolated to eliminate any bacterial contamination, although axenic cultures were difficult to maintain. Moss (1973) however feels that exponentially growing cultures are probably not affected by bacterial interferences. In his work, he found that algae required the addition of vitamins even with bacteria present and therefore accepted growth measurements obtained with vitamin utilization in non-axenic cultures as valid. Also, Tassigny (1971) considers the results with unialgal desmid cultures in mineral medium to be equally valid to those in axenic culture.

Batch cultures of $150 \mathrm{ml}$ in $250 \mathrm{ml}$ flasks or $250 \mathrm{ml}$ in $500 \mathrm{ml}$ flasks were used to maintain a similar surface to volume ratio and prevent carbon limitation. For short term ( 2 days) nitrate uptake experiments, 1 liter of culture was maintained in a $2800 \mathrm{ml}$ flask.

To minimize contamination, the medium was filter sterilized. The autoclaving process may add metals and change the activity level of the copper so filtration was the sterilization method preferred. To obtain copper activity close to the predicted value, a Chelex column was eluted with FRAQUIL (without trace metals added) to remove contaminant trace metals (Morel et al., 1978). The trace metals required in FRAQUIL were then added and the medium was filter sterilized ( 0.45 micrometers Millipore filter). Glassware was not autoclaved due to metal contamination; some bacterial contamination may have occurred with the 
acid wash procedure but testing for bacterial growth showed it was minimal.

Copper sulfate was added to FRAQUIL in the experimental flasks and the medium was allowed to equilibrate 24 hours before the organisms were added (when EDTA was the buffer). When TRIS was used as a buffer in systems where copper was added, equilibration was considered to occur almost instantaneously and the organisms were added within a half hour after the copper had been added.

\section{Preparation of Copper Solution}

Copper sulfate $\left(\mathrm{CuSO}_{4} \cdot 5 \mathrm{H}_{2} \mathrm{O}\right)$ was added to sterile deionized water to give a $10^{-1} \mathrm{M}$ solution. This stock solution was stable and could be stored in the refrigerator indefinitely.

\section{COPPER CONCENTRATION AND SPECIATION}

The toxic effect of copper on organisms is determined by the amount of copper in the ionic form, $\mathrm{Cu}^{2+}$, rather than total concentration of all forms of copper (lab results of Sunda and Guillard, 1976; calculations of Jackson and Morgan, 1978; and field results of McKnight, 1981). EDTA acts as chelator for copper and was present in FRAQUIL at $5 \times 10^{-6} \mathrm{M}$. If the total concentration of copper is less than the total concentration of EDTA there is a defined system with no problems of copper precipitation. 
The final dilutions of copper in the experimental flasks in the long term growth experiments were $1.3 \mathrm{x}$ $10^{-6} \mathrm{M}, 10^{-7} \mathrm{M}$, and $10^{-8} \mathrm{M}$ with EDTA as the buffer. When TRIS was added as a buffer in short term experiments, to a final concentration of $10^{-3} \mathrm{M}$, copper concentrations were increased to $10^{-5} \mathrm{M}$.

Copper activity (concentration of $\mathrm{Cu}^{2+}$ ) was calculated by means of the MICROQL program using constants of components in the experimental medium FRAQUIL (Westall et al., 1976). Computed copper activity (expressed as $\mathrm{pCu}^{\star}$, the negative log of cupric ion concentration) in long term experiments with EDTA as the buffer ranged from 12.1 to 15.4 . (See Table II and Figure 7.) $\mathrm{pCu}^{*}$ as referred to in this work is always calculated and not measured. When the medium was eluted through the Chelex column, the $\mathrm{pCu}$ actual values are assumed to be very close to the values calculated with MICROQL $\left(\mathrm{pCu}^{*}\right)$. This calculation of copper activity does not include organic complexation that may occur during growth, therefore it represents maximum toxicity, i.e. minimum values of $\mathrm{pCu}$ (Sunda et al., 1981).

Swallow et al. (1978) used an ion electrode to measure the depression of cupric ion concentration by phytoplankton exudates and found that only one in 8 algal species excreted copper complexing materials. McKnight (1979) also measured organic products but earlier attempts to measure excretion products of algae in laboratory conditions were not successful because of their low concentration (Fogg, 1977). Darling 
TABLE II

\section{CALCULATED COPPER ACTIVITITES}

IN FRAQUIL WITH EDTA

$\begin{array}{lr}\text { Copper Molarity } & \text { pCu* } \\ 1 E-3 & 3.6 \\ 1 E-5 & 5.5 \\ 9 E-6 & 5.5 \\ 7.5 E-6 & 5.7 \\ 6 E-6 & 6.0 \\ 4 E-6 & 10.8 \\ 2 E-6 & 11.8 \\ 1.3 E-6 & 12.1 \\ 1 E-6 & 12.3 \\ 1 E-7 & 13.4 \\ 1 E-8 & 14.4 \\ 9.97 E-10 & 15.4 \\ {[E D T A]=5 \times 10^{-6} \mathrm{M}} & \end{array}$




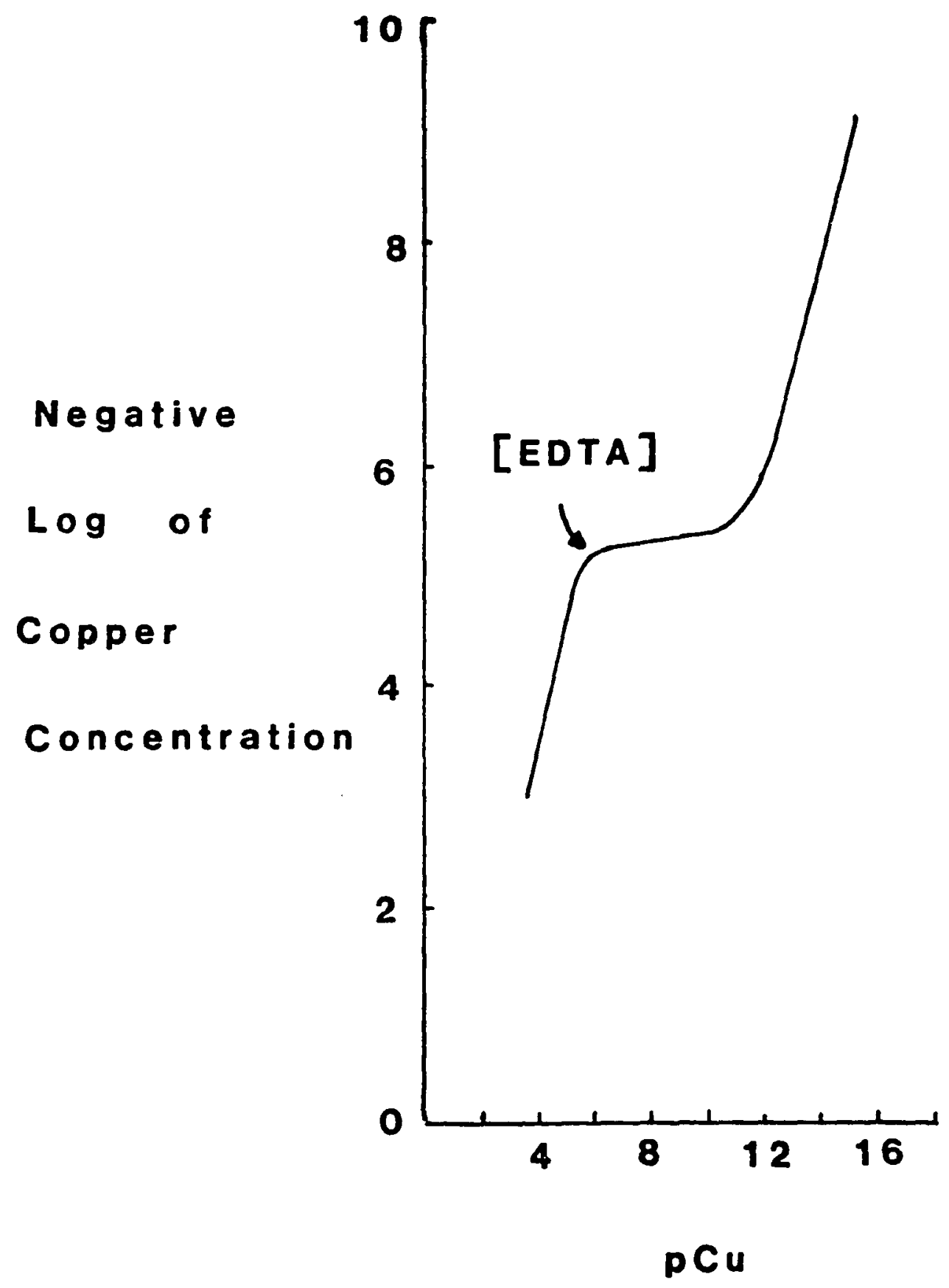

Fiqure 7. Negative log of copper concentration in the medium FRAQUIL vs. calculated copper activity. Arrow indicates EDTA concentration in the medium. 
(1979) found extracellular release of organic products of Selenastrum capricornutum had a small but significant effect on ionic copper.

\section{PH MEASUREMENT}

pH was routinely measured with an Ionalyzer specific ion meter model 404. The beginning $\mathrm{pH}$ of autoclaved FRAQUIL and of Chelexed FRAQUIL with trace metals added was the same (7.05). When the various amounts of copper were added to the experimental flasks, the $\mathrm{pH}$ did not vary significantly. The $\mathrm{pH}$ at the end of the experiments was not alkaline indicating the flasks were not carbon limited. The effects seen in the experiments were considered to be the result of copper treatment, not of $\mathrm{pH}$ changes.

The $\mathrm{pH}$ increased during zygote maturation (up to 7.87 ) and remained high during germination (7.94).

The solubility diagram of copper (Figure 8 ) shows the cupric ion to be available at the experimental pH.

\section{MONITORING CELL GROWTH}

\section{Cell Counts}

A Sedgwick-Rafter counting chamber was used for cell counts; the cells present in the total milliliter were counted so non-uniform distribution within the counting chamber would not contribute to counting error (McAlice, 1971). For long range ( 3 weeks) experiments, initial cell density ranged from 16 to 112 cells/ml; final cell density reached 


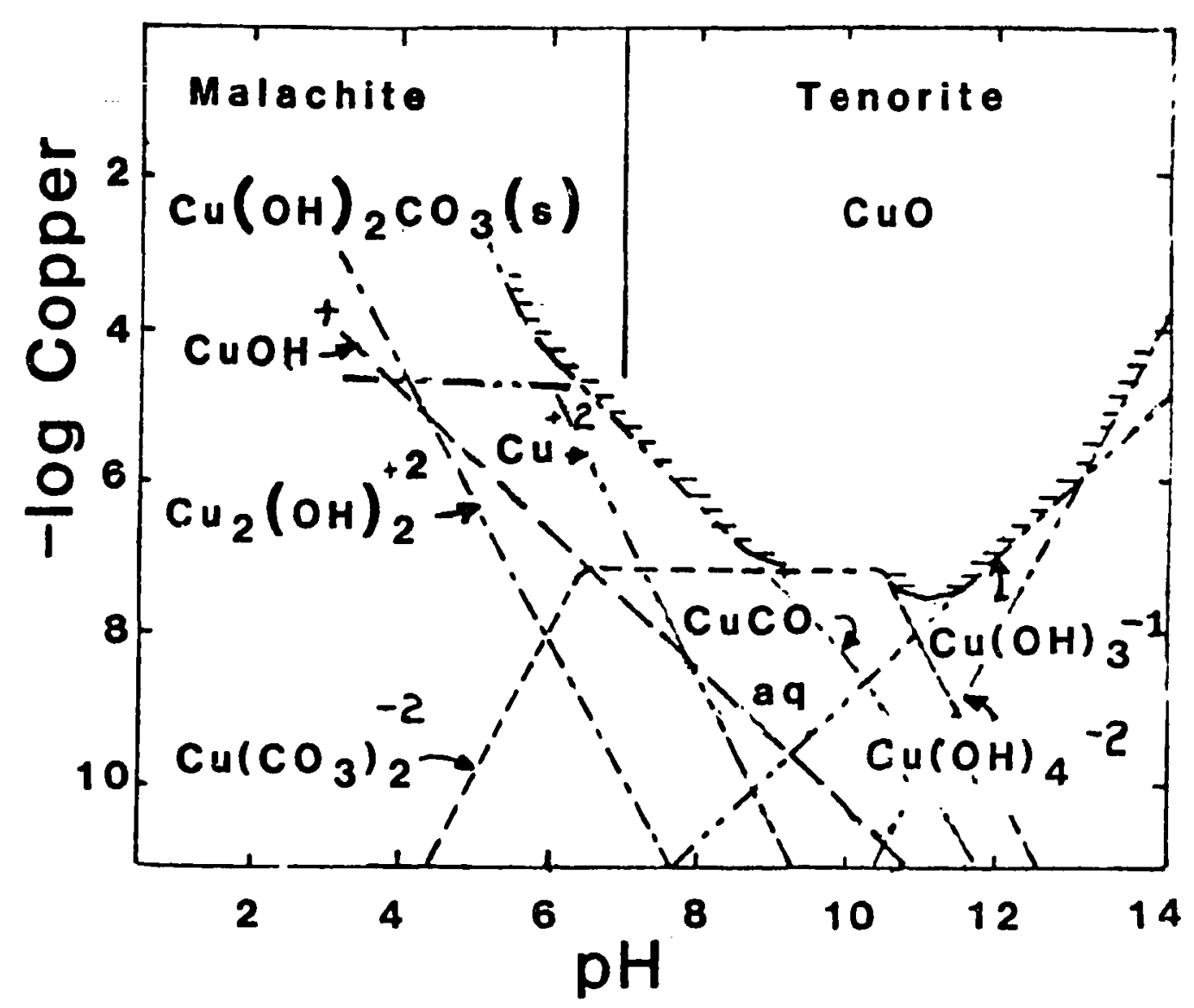

Figure 8. Solubility diagram of copper. The solid line surrounding the shaded area gives the total solubility of $\mathrm{Cu}$ (II) which up to $\mathrm{pH}$ value of 6.96 , is governed by the solubility of malachite, $\mathrm{Cu}_{2}(\mathrm{OH})_{2} \mathrm{CO}_{3}(\mathrm{~s})$. In the low pH region azurite, $\mathrm{Cu}_{3}(\mathrm{OH})_{2}\left(\mathrm{CO}_{3}\right)_{2}(\mathrm{~s})$ is metastable but may become stable at higher $t_{\mathrm{T}}$. Above $\mathrm{pH} 7$ the solubility is controlled by the solubility of Cuo (tenorite). The predominant species with increasing $\mathrm{pH}$ are $\mathrm{Cu}^{2+}, \mathrm{CuCO}_{3}(\mathrm{aq}), \mathrm{Cu}\left(\mathrm{CO}_{3}\right)_{2}{ }^{2-}$ and hydroxo copper(II) anions. $C_{\mathrm{T}}=10^{-2}$ (Stumm and Morgan, 1970). 
a maximum of $6100 \mathrm{cells} / \mathrm{ml}$. Dilutions were made for counts when cell number exceeded 600 cells/ml. The counting chamber and cover glass were cleaned with water and rinsed in $95 \%$ ethanol after each count.

\section{Cell Morphology}

Quantitative assessment of changes of gross cell morphology was done during long term growth experiments by grouping the cells into three categories: those cells of normal size and shape (Figures 9 and 10); those of abnormal size and shape that completed cytokinesis (Figures 11 and 12); and those incapable of completing cell division (Figures 13 and 14 ). Those cells incapable of finishing cell division were recognized when 2 mature symmetrical cells were contained within a continuous cell wall. The latter two categories of cells are considered to be under stress due to copper.

\section{Sexual Reproduction}

The onset of sexual reproduction in long term growth experiments was monitored. The frequency of sexual reproduction was determined by counting the number of zygotes and the number of potential zygotes (abortions) and comparing that number to the total number of cells with this equation:

$\therefore$ Sexual Reproduction $=\frac{2(\# \text { Zygotes }+ \text { Abortions })}{\# \text { Cells }+2(\# \text { Zygotes }+ \text { Abortions })}$ 
37
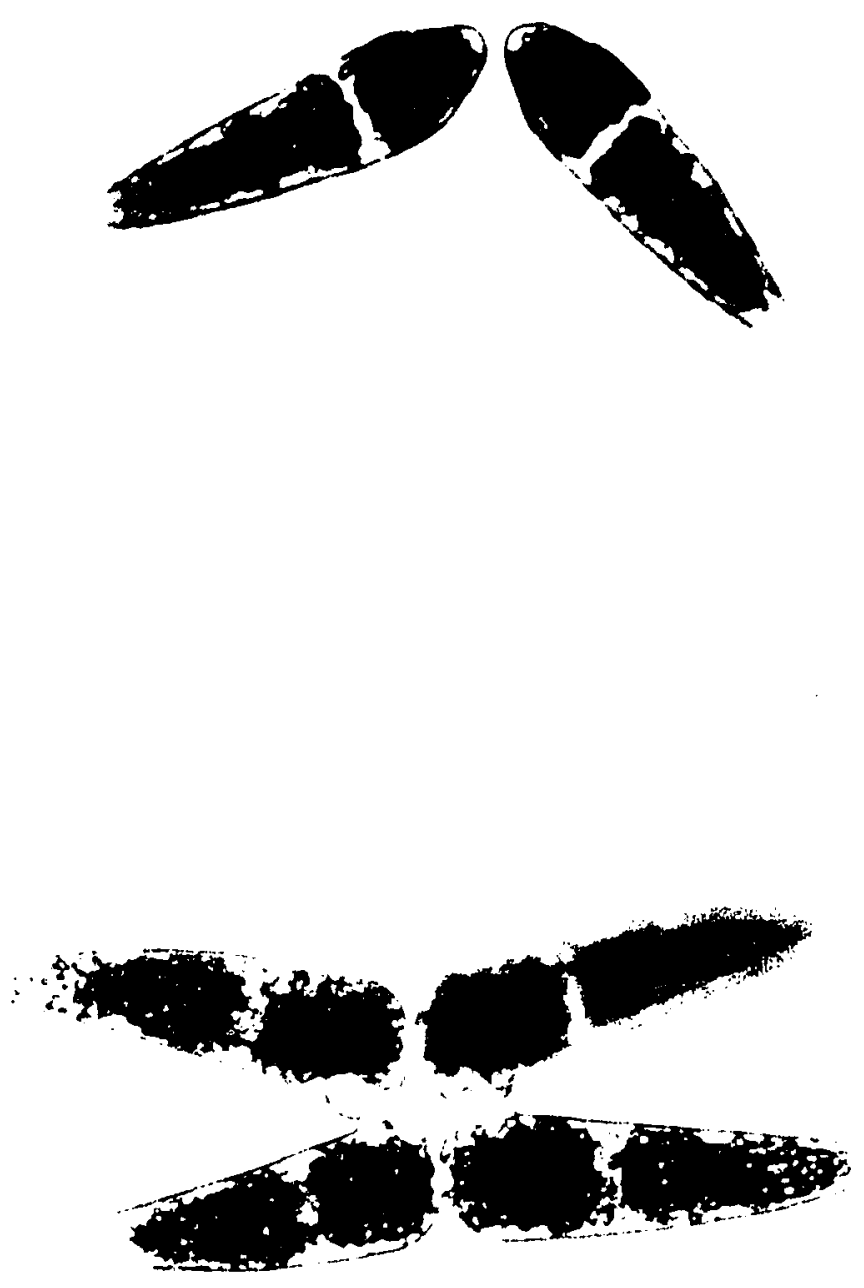

Figures 9 and 10 . Photomicrographs of strain \#96

(Top) and strain \#17l (Bottom) without copper

treatment. The cells shown here are immature cells pairing before sexual reproduction. LM $430 \mathrm{X}$. 

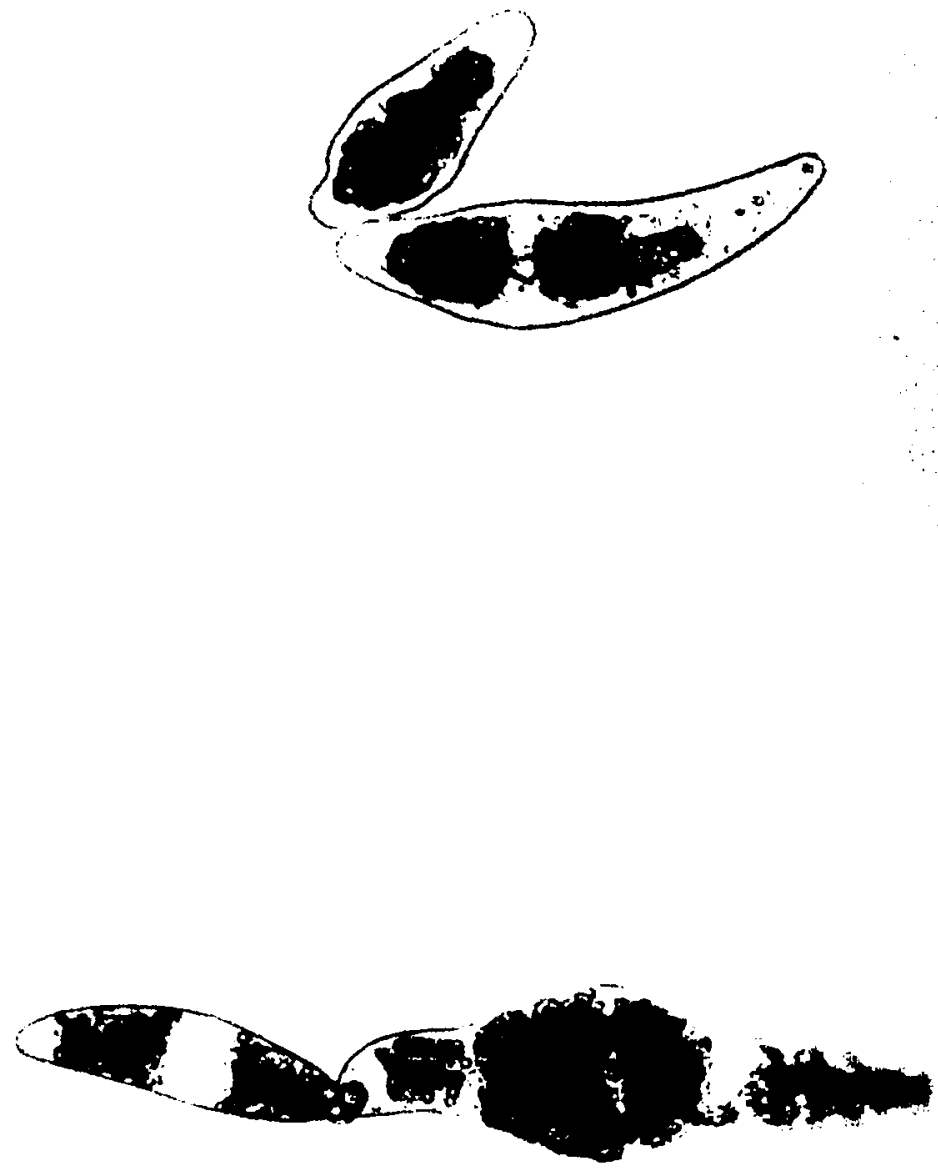

Figures 11 and 12. Photomicrographs of abnormal cells of strain \#96. LM $430 \mathrm{x}$. 
39
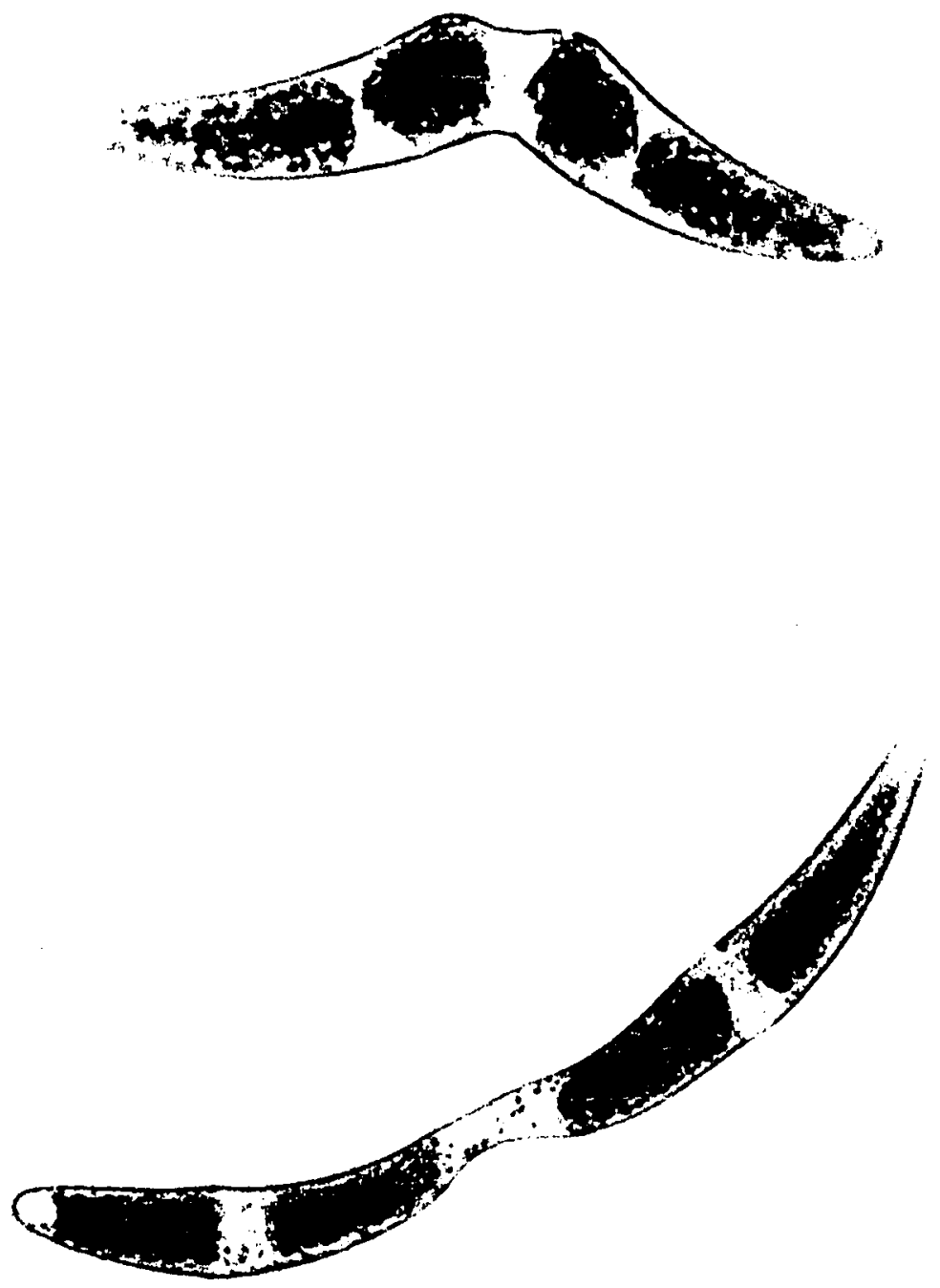

Figures 13 and 14. Photomicrographs of strain \#96 that have not completed cytokinesis. LM $430 \mathrm{x}$. 
Determination of Cell Chlorophyll

The amount of chlorophyll was determined by the fluorometric method of Strickland and Parsons (1972). There was no significant difference in chlorophyll amounts using the processes of filtration or centrifugation, so, for convenience, the pellet from a sample centrifuged for nitrate analysis was used.

One capillary drop of saturated $\mathrm{MgCO}_{3}$ was added to prevent acid conditions which would decompose the chlorophyll to give phaeophytin pigments. Ten ml of $90 \%$ acetone was the total amount used for extraction. In dim light, a few $\mathrm{ml}$ of $90 \%$ acetone were added to the pellet in the centrifuge tube; this was transferred to a grinding tube. The centrifuge tube was rinsed with more acetone and the rinse was added to the grinding tube. Cells were ground for 2 minutes at the highest speed on an Eberbach PowerStir. The ground cells were transferred back to the centrifuge tube for overnight extraction. The grinding tube and pestle were rinsed until the total $10 \mathrm{ml}$ of $90 \%$ acetone was added. The tube was capped and covered with aluminum foil and refrigerated for 24 hours.

The amount of chlorophyll was determined by use of a Turner fluorometer which was calibrated using a Bausch and Lomb Spectronic 100. On the Spectronic 100, readings were taken at wavelengths of 665,645 , and $630 \mathrm{~nm}$ for use in the Strickland and Parsons formula: 


$$
\text { chlorophyll } \mathrm{a}=11.6 \mathrm{E}_{665}-1.31 \mathrm{E}_{645}-0.14 \mathrm{E}_{630}
$$

where $E=$ extinction at these wavelengths.

Using this same sample, an F factor was determined on the fluorometer:

$$
F \text { factor }=\frac{\text { chlorophyll a (calculated from (3)) }}{\text { reading on fluorometer }}
$$

Using this $F$ factor value, subsequent chlorophyll amounts were determined by a single reading on the fluorometer. The filters used in the fluorometer were \# $47 \mathrm{~B}$ as the primary filter and \# $2 A 15$ as the secondary filter (Turner). Cell counts were taken of the same samples so the amount of chlorophyll per cell could be calculated.

\section{Carbon Uptake as a Function of Copper}

The cultures contained TRIS so equilibration would occur quickly (within the first 5 minutes) when copper was added (Anderson and Morel, 1978). Copper was added to the test flasks to give a final concentration of $10^{-5} \mathrm{M}$. To the copper treated flask and a control flask $(100 \mathrm{ml}$ of culture) were added 100 microliter of ${ }^{14}$ carbon ( 1 microcurie/mI). For background count, a third flask without 14 carbon or copper added was run in parallel. Triplicate samples were taken at 16 hours and 40 hours. Ten ml of sample were filtered onto a whatman GF/C glass microfibre filter $(24 \mathrm{~mm})$. The filter was placed in a grinding tube for chlorophyll extraction. The method for chlorophyll determination was the same as above. After overnight 
extraction, the samples were centrifuged and chlorophyll readings were done of the supernatants. The pellet and supernatant were then recombined in a scintillation vial and the acetone was allowed to evaporate under an intense light. When dry, $8 \mathrm{ml}$ of scintillation liquid (Scinti Verse I, Fisher Scientific Company) were added. Radioactivity counts were taken for 5 minutes on a Beckman Scintillation Counter.

The filtrates of the samples were analyzed for fixed ${ }^{14}$ carbon as an indicator of excreted organics. The $\mathrm{pH}$ of the filtrate was lowered to $\mathrm{pH} 2$ by adding 2 drops concentrated HCl. Air was bubbled through the liquid continuously for a few hours, with an occasional shaking of the sample to wash the sides of the scintillation vial. Eight ml of scintillation liquid were added and samples were read as above.

Gloves were used throughout the procedure and all materials were soaked after use for 24 hours in Count-off (New England Nuclear) and thoroughly rinsed with water.

$$
\text { NITROGEN UPTAKE AS A FUNCTION OF COPPER }
$$

\section{Long Term Nitrate Uptake and Growth}

Growth experiments were run for three weeks to examine the relationship between nitrate taken up by the cells and the time of induction of sexual reproduction. Control and experimental flasks were run in duplicate. Experimental flasks had pCu* of 12.1 - 14.4. Control flasks had pcu* 
of 15.4. Inocula were added to $250 \mathrm{ml}$ of FRAQUIL containing 100 micromoles/l nitrate. Cell counts and samples for nitrate determination were taken every 2 days until sexual reproduction or the stationary phase of growth occurred.

\section{Short Term Nitrate Uptake}

When cultures were depleted of nitrate, a spike of nitrate (final concentration of 10-20 micromoles/1) was added. Subcultures of $75 \mathrm{ml}$ were taken and dispensed into flasks designated as controls and experimental flasks. A cell count was taken and $\mathrm{pH}$ was measured. To the experimental flasks, copper concentrations were added. The flasks were swirled left to right and right to left for 15 minutes. The completion of this mixing was considered zero time and a sample was taken for nitrate amount. The amount of nitrate was found to be consistent in all flasks at 0 time. Samples were taken periodically for 48 hours (at 5, 19, 24, and 48 hours) until nitrate was virtually depleted in the control flasks.

Other short-term uptake experiments were done with the nitrate spike being added 5 hours before the copper was added. It was necessary to use TRIS as a buffer to provide rapid equilibrium.

Long Term Ammonium Uptake and Growth

To determine if copper more directly affected nitrate uptake than ammonia uptake, long term growth experiments were also done with ammonia as the nitrogen source. To 
test for ammonia uptake, nitrate was not added to the media; $\mathrm{NaNO}_{3}$ was replaced by the same molarity $\left(10^{-4} \mathrm{M}\right)$ solution of $\mathrm{NH}_{4} \mathrm{Cl}$. The $\mathrm{pH}$ of both solutions were adjusted to 6.96 . The final molarity of copper added was $1.35 \times 10^{-6}$ which gives a $\mathrm{pCu}^{*}$ in the nitrate media of 12.1. Less than 1 micromole nitrate was present in the FRAQUIL with $\mathrm{NH}_{4} \mathrm{Cl}$. The procedure here was the same as for long term nitrate uptake.

Measurement of Nitrate

Each time a sample was taken for nitrate determination, a cell count was also done. The sample for nitrate determination was centrifuged on a Universal Model U Centrifuge at approximately $750 \mathrm{~g}$ for 20 minutes. Nitrate determination of the supernatant was done immediately or it was frozen for later testing. Nitrate was measured using the method proposed by Strickland and Parsons (1972) and later modified by Eppley (1978). It is assumed that all nitrate not in the medium has been taken into the cells.

A cadmium-copper reduction column was used to reduce the remaining nitrate in the supernatant to nitrite; nitrite was then measured spectrophotometrically. When a sample was reduced, part of it was sent through the column to act as a pre-wash to assure a more accurate reading. Although the nitrate reduction column used was a scaled down model for use with small samples (Rueter, 1979), a $5 \mathrm{ml}$ wash was not adequate to completely wash out the previous sample. 
Reducing samples of 0.1 micromole nitrate after a 100 micromole sample gave readings of $25 \times$ the expected value due to carryover. Washes of $20 \mathrm{ml}$ with a $5 \mathrm{ml}$ sample collected for nitrate testing resulted in consistent readings.

All samples to be run through the column were made basic with concentrated ammonium chloride (100 microliters per $5 \mathrm{ml}$ ). This was done because basic solutions tend to clear the column more thoroughly (Strickland and Parsons, 1972). As soon after reduction as possible, 100 microliters of sulfanilamide were added to the $5 \mathrm{ml}$ sample to form a diazonium salt with the nitrite. After 3 minutes reaction time, 100 microliters of NEDA ( $\mathrm{N}$-l-napthyl-ethylene-diamine dihydrochloride) solution were added to form the red azodye. Complete color development occurred within 10 minutes and samples needed to be read within 2 hours. Samples were read at $543 \mathrm{~nm}$ on a Bausch and Lomb Spectronic 100. Dilutions were made to read samples above 30 micromoles $\mathrm{NO}_{3}$ (extinction levels above 0.900 ).

Because of the difference between columns, a standard curve (with standards of $1,5,12.5,25,50$, and 100 micromoles nitrate/1) was run on each column each time (Figure 15).

FRAQUIL had 100 micromoles of nitrate present before inoculation of cells. The amount of nitrite in the medium was measured by testing for nitrite without the medium passing through the column. The amount of nitrite in FRAQUIL was negligible. 


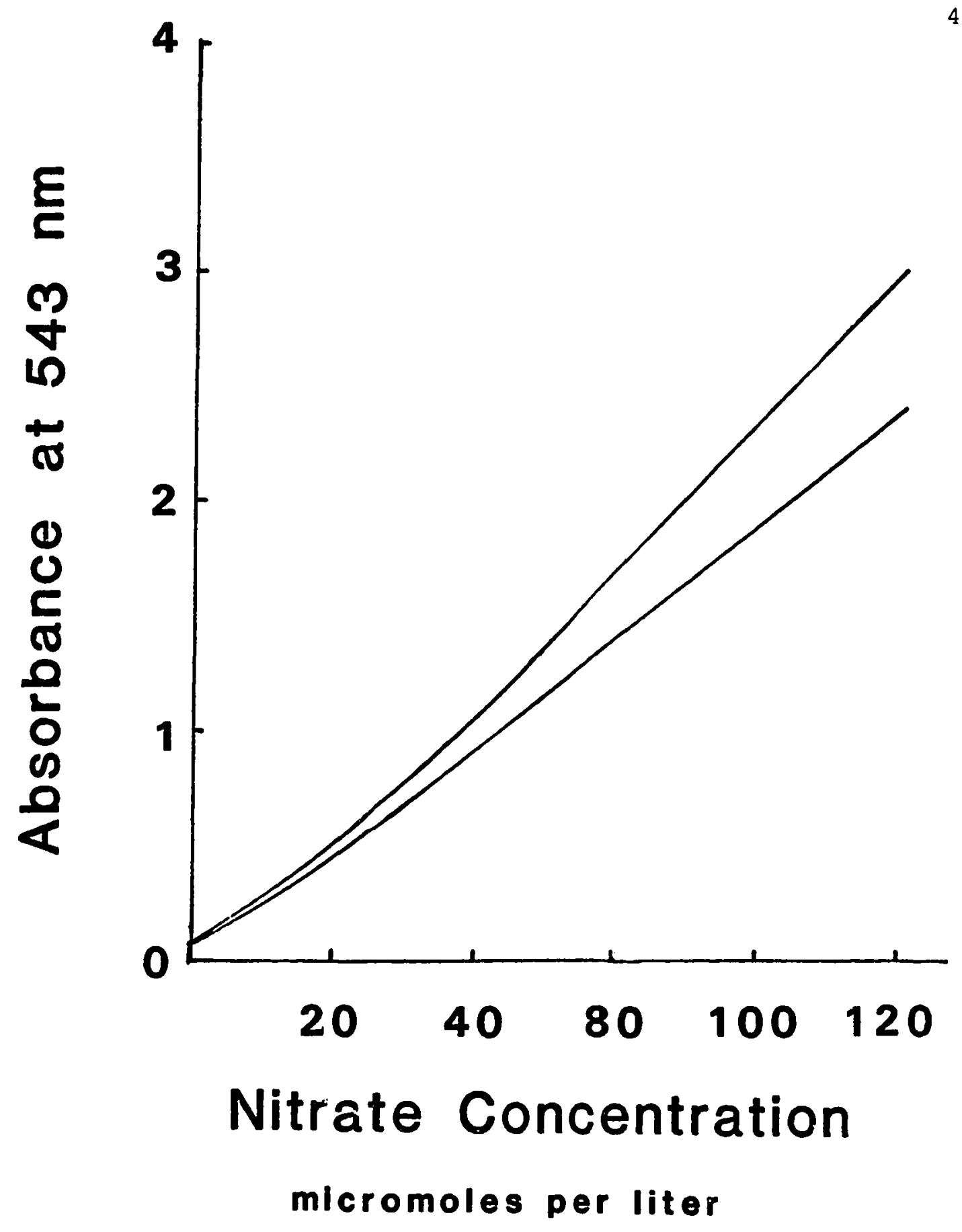

Figure 15. Absorbance $(543 \mathrm{~nm})$ vs. concentration of nitrate. The two lines represent standard curves from two different nitrate reducing columns. 
An ideal rate of passing through the column was 5

$\mathrm{ml}$ in less than 5 minutes. If a column became sluggish, moving the liquid through it by using forced air cleared the column temporarily to obtain a faster rate. When sluggish, or after 100 samples were reduced, the columns were reactivated by placing the cadmium filings in $5 \% \mathrm{v} / \mathrm{v} \mathrm{HCl}$, rinsing them in distilled water until the $\mathrm{pH}$ was greater than 5, and then saturating the filings in a $2 \%$ copper solution. The column was then repacked (Strickland and Parsons, $1972)$.

A solution of dilute $\mathrm{NH}_{4} \mathrm{Cl}$ was used to pass through the column between samples that had great differences of nitrate concentration. The dilute $\mathrm{NH}_{4} \mathrm{Cl}$ was also used on the columns in storage; parafilm over the open top of the glass columns assured that the columns would not evaporate to dryness when not in use.

Measurement of Ammonia

The amount of ammonia present in the medium was measured with an Orion ammonia electrode (model 95-10). While being constantly stirred with a magnetic stirrer, a $25 \mathrm{ml}$ sample was treated with $2.5 \mathrm{ml}$ of $10 \mathrm{M} \mathrm{NaOH}$. The reading was recorded when it became stable.

Determination of Nitrate Reductase Activity

The basic procedure for determining activity of nitrate reductase (ferrocytochrome:nitrate oxidoreductase EC. No. 1.9.6.1) was as follows. Samples were harvested by 
centrifugation at $2800 \mathrm{~g}$ for 20 minutes or by the process of filtration. The supernatant was discarded and the cells were homogenized with a glass homogenizer in ice in a homogenizing solution consisting of $3 \mathrm{ml} 0.15 \mathrm{M} \mathrm{KPO}_{4}$ buffer $(\mathrm{pH} 7.0), 0.6 \mathrm{ml}$ sodium dithionite or dithiothreitol, and $20 \mathrm{mg}$ polyvinylpyrrolidone. The sodium dithionite (or dithiothreitol) was used to maintain integrity of the enzyme (Lewis et al.. 1982) and the polyvinylpyrrolidone was used to eliminate interference from phenols (Klepper and Hageman, 1969; Stock and Lewis, 1982).

The assay is that of Lowe and Evans (1964) wherein the reaction velocity was determined by measuring the production of nitrite in a dithionite/methyl viologen system. One unit produces one micromole of nitrite/minute at $30^{\circ} \mathrm{C}$ and at pH 7.0 under specified conditions.

Test tubes were placed in a $30^{\circ} \mathrm{C}$ bath. To these tubes were added $0.1 \mathrm{ml}$ phosphate buffer, $0.1 \mathrm{ml} 0.02 \%$ methyl viologen, $0.1 \mathrm{ml} 23 \mathrm{mM}$ sodium dithionite prepared in $48 \mathrm{mM}$ sodium bicarbonate solution, $0.1 \mathrm{mI} 0.10 \mathrm{M} \mathrm{NaNO}_{3}$ and $0.1 \mathrm{mI}$ $0.05 \mathrm{M} \mathrm{MgSO}_{4}$. One tenth of a milliliter of copper sulfate $\left(10^{-3}\right.$ to $\left.10^{-9} \mathrm{M}\right)$ was added to the experimental tubes. After 5 minutes of temperature equilibration, $0.1 \mathrm{ml}$ enzyme or cell extract $\left(0.1 \mathrm{ml} \mathrm{H}_{2} \mathrm{O}\right.$ for blank) was added and incubated for 30 minutes. The reaction was stopped by vigorous aeration until blue color was completely removed. $0.5 \mathrm{ml}$ sulfanilamide ( $58 \mathrm{mM}$ in $3 \mathrm{~N} \mathrm{HCl}$ ) and $0.5 \mathrm{ml}$ NEDA solution (0.39 mM N-l-napthyl-ethylene-diamine dihdrochloride) were 
quickly added to the test tube. $1.5 \mathrm{ml}$ glass distilled water was added and 10 minutes time allowed for color development at room temperature. Samples were read at 543 nanometers.

Using the known activity of purified enzyme (E. EOli) as a reference, the filtered sample yielded activity of $2.9 \times 10^{-5}$ units cell-1 minute m $^{-1}$ whereas the centrifuged sample yielded activity of $1.7 \times 10^{-5}$ units cell-1 minute ${ }^{-1}$. When copper was added in preliminary experiments to give a final molarity of $10^{-3} \mathrm{M}$ copper, no enzyme activity was produced. This indicates that copper does directly affect the activity of nitrate reductase, which was indicated in the long term and short term nitrate uptake experiments.

Enzyme activity from cell extracts of Closterium moniliferum did not always occur, however, so modifications of the basic procedure above were tried. Assuming the lack of activity was due to the enzyme being attached to the membrane, drastic steps were taken to disrupt the cells. Besides homogenization, the French press, Triton $X$, and glass beads in a mortar and pestle in various combinations were used. To determine if the French press procedure was too harsh a procedure and was destroying the activity of the enzyme, purified enzyme (obtained from E. coli. Sigma) was run through the French press twice. There was a loss of 448 of the activity. With the homogenization process, the purified enzyme activity decreased by 428 . 
NADH was not an acceptable electron donor for purified enzyme or cell extract; both methyl viologen and benzyl viologen were suitable electron donors. The addition of FMN did not affect enzyme or extract activity.

The solution of sodium dithionite needed to be prepared fresh just before use. Its freshness was tested by observing a deep blue color formed when combined with methyl viologen which indicated a reducing environment.

To determine if the experimental procedure was proper, tests with purified enzyme were always run when testing cell extract.

Since copper was to be added to the test tubes to test its effect on enzyme activity, TRIS buffer was necessary for rapid equilibration. One-tenth of a milliliter of $10^{-3}$ TRIS buffer was added to the reaction tubes. This addition did not significantly decrease enzyme activity.

Other variables that might have contributed to the inconsistency of the procedure were tested. These included temperature, time (from 1 minute up to 24 hours), excess and minimum sodium dithionite or dithiothreitol, and use of cultures that were nitrate depleted (with nitrate spike added to induce enzyme production) or cultures that were actively growing. Sodium salts were removed since Tischner (1976) reported that nitrate reductase activity did not occur in a $\mathrm{K}-\mathrm{Na}-\mathrm{PO}_{4}$ buffer. These changes did not produce activity in the supernatant; often, some nitrate reductase activity was present in the cells. Supernatants were tested 
after each step in the procedure. Simple homogenization of a mixed algal culture produced enzyme activity however. This indicates that there is a special problem in releasing the enzyme from closterium moniliferum cells or in maintaining its activity.

\section{PHOTOGRAPHY}

\section{Light Microscopy}

Gross cell morphology was observed with a Zeiss microscope and recorded with a Zeiss c35 camera. Film used was black and white Plus-X-Pan ASA 125/22 DIN. Magnification of the cells was $100 \mathrm{x}$ or $430 \mathrm{x}$.

\section{Scanning Electron Microscopy (SEM)}

The cells were grown in liquid medium and therefore needed to be attached to a substrate for SEM work. Polycarbonate filters were chosen because they were not soluble in the ethanol used for dehydration purposes and they were able to survive the critical drying process. They were also found to be an unobtrusive background for the organisms as compared to glass filters. While the cells were filtered, they were rinsed with FRAQUIL and never were allowed to become completely dry. The filter, with cells attached, was placed in a fixative composed of 3-4\% formalin, $0.75 \%$ glutaraldehyde, and phosphate buffer of $\mathrm{pH} 7.0$ (Fahrenbach, personal communication). The preparation of the fixative and all manipulations with the fixative were 
done under a hood because of the toxicity of the formalin and glutaraldehyde.

After overnight fixation at room temperature, the samples were rinsed with buffer and sequentially dehydrated through 20\%, 40\%, 60\%, and $80 \%$ ethanol solutions in 5 minute intervals. The samples were then transferred to absolute alcohol until they could be placed in the transitional fluid, Freon. The transitional fluid was necessary to prevent morphological changes in the cells by eliminating the liquid-gas interfaces as the samples were processed through the critical point drying. The critical point dryer used was a Model Hummer 1 by Technics. When dry, the filters were attached to SEM studs with double sticky tape and then coated with gold. Coating with gold makes the sample conductive for observation. Photographs were taken with Polaroid 55 positive/negative film. Magnifications ranged from $100 \mathrm{x}$ to $5000 \mathrm{x}$ on an AMR Model 1000 scanning electron microscope using $20 \mathrm{kv}$.

$$
\text { PRESENTATION OF DATA }
$$

Graphs were plotted on an interactive Digital Plotter using a Tektronix 4051 with a program for $X-Y$ plot and the calibration curve for nitrate standards modified by Jim Sweet (personal communication). 
CHAPTER III

\section{INHIBITION OF GROWTH AND CELL \\ DIVISION BY EXCESS COPPER}

\section{INTRODUCTION}

Cell division was definitely inhibited by the addition of excess copper to batch cultures of closterium moniliferum. There was an increased lag phase in long term experiments and delayed onset of sexual reproduction. The increased lag phase indicates the effect of copper is on the process of cell division j.tself. Chlorophyll measurements and ${ }^{14} \mathrm{C}$ uptake show, however, that these aspects of metabolism were also affected.

A toxic sublethal amount of copper causes an increased lag phase, which can eventually be overcome with the culture reaching a normal growth rate. Smaller amounts of copper may be stimulatory to growth and beneficial to the organisms. The evidence for copper's effect is presented in this chapter as growth patterns, growth rate, cell division and morphology, chlorophyll content and ${ }^{14}$ carbon uptake.

The effect of copper was examined by long term experiments of 3 weeks duration where cell division, nitrogen (nitrate or ammonia) remaining in the medium, and onset of sexual reproduction were monitored. It was shown here 
that copper affected all of these processes. The first process is discussed in this chapter; the latter two are presented in Chapter IV.

Micrographs were used to examine aberrant morphology to determine if there was a correlation between changes in cell number and morphological changes. Further study of morphology is presented in Chapter $v$.

\section{RESULTS AND DISCUSSION}

\section{Growth Patterns}

When copper was added to batch cultures of Closterium moniliferum, initial cell division was inhibited and an increase in lag phase was observed at $\mathrm{pCu}$ * below 14.4 (Figure 16). FRAQUIL medium, with no added copper, has a pCu* of 15.4. (pCu* is calculated activity of copper ion $=-\log \left[\mathrm{Cu}_{\mathrm{aq}^{2+}}{ }^{2+}\right)$ Cultures with lower beginning $\mathrm{pCu}$ * were able to overcome this increased lag phase and were able to attain high maximum cell number. In some cases, the cultures with increased lag phase at $\mathrm{pCu} * 12.1$, surpassed the maximum cell number of those cultures with no copper added (Strain 96, Figure 17). This suggests an adaptability of the cells with time with the effect of copper occurring during the lag phase. It is possible that the lag phase may be overcome by exudation from living cells or leaching from dead cells to render the heavy metal less toxic by chelation (Braek et al., 1976). 


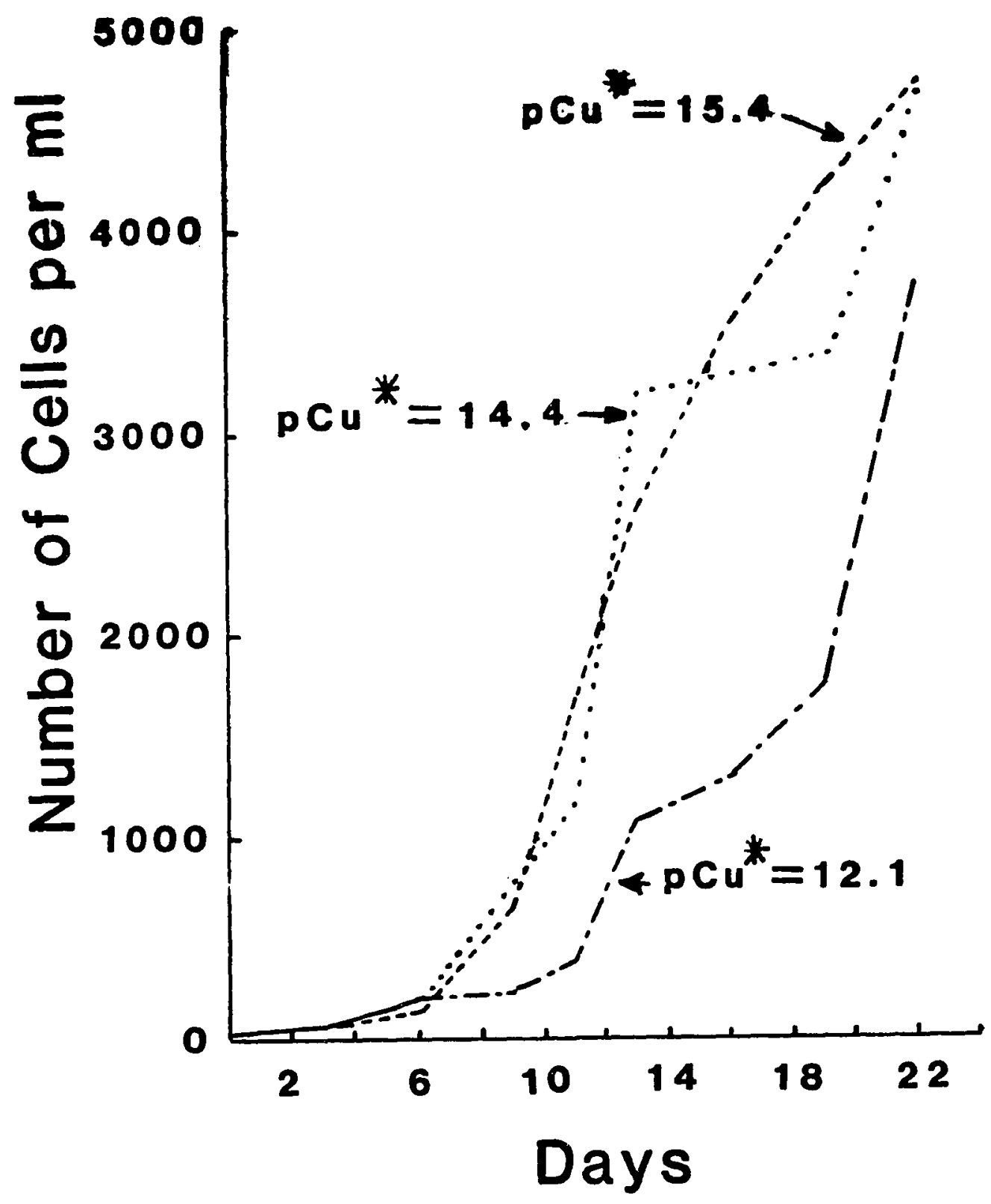

Figure 16. Number of cells per $\mathrm{ml}$ vs. time (days) instrain 96 of Closterium moniliferum. Growth was inhibited at $\mathrm{pCu} \mathrm{u}^{*} 12.1$ in the first days of the growth curve. 


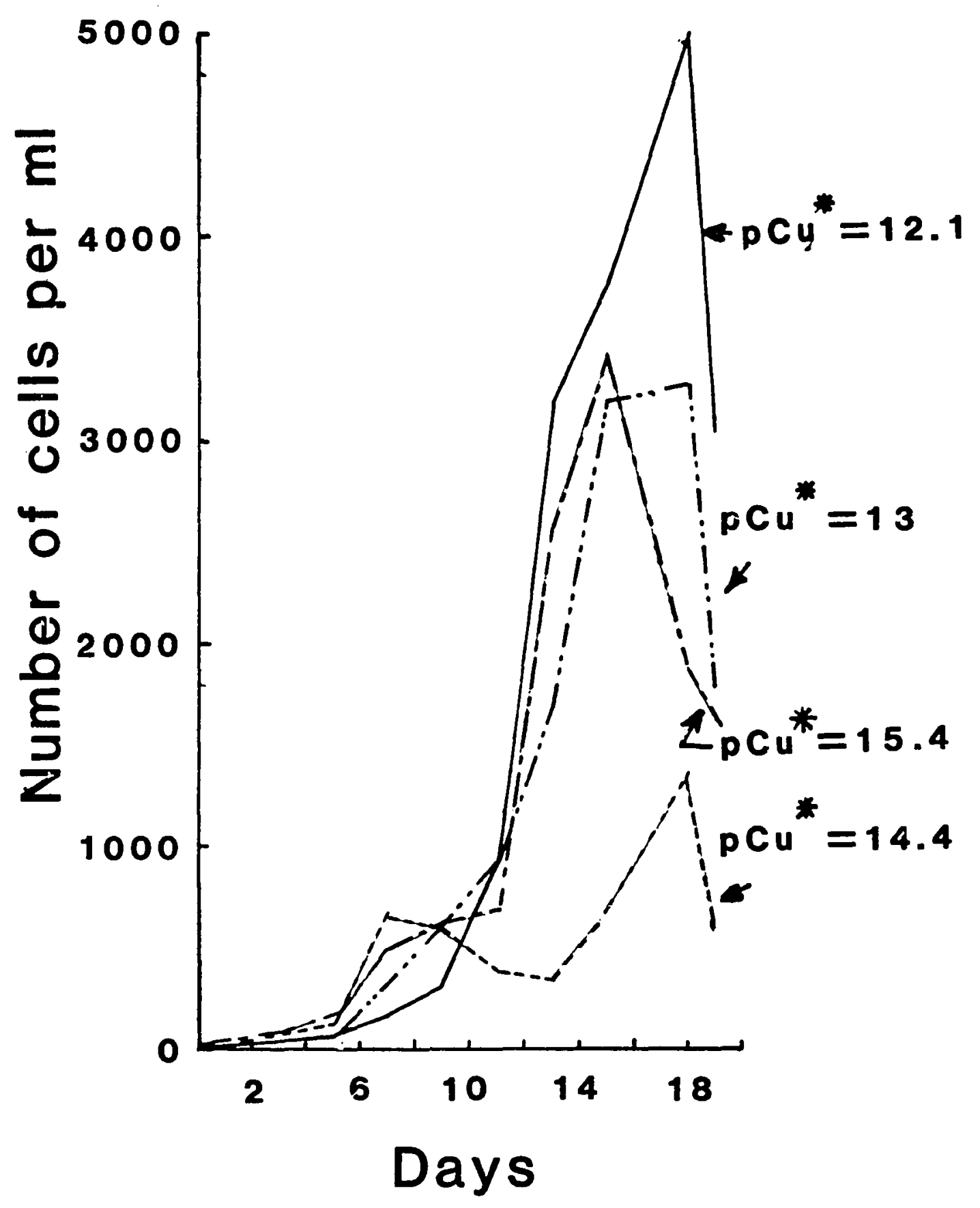

Figure 17. Number of cells per $\mathrm{ml}$ vs. time. Strain 96 of Closterium moniliferum. 
The stimulatory effect of $\mathrm{pCu}^{*} 14.4$ and the similar responses at $\mathrm{pCu} * 13.4$ and 15.4 in strain 96 exemplify the typical dose response of biological organisms to a trace metal (See Figure 1).

In strain 171, the addition of small amounts of copper did not inhibit growth. The final cell density was highest in this instance at $\mathrm{pCu} * 14.4$ (Figure 18).

Figure 19 includes error bars on the growth curve; these may appear to be rather large in some instances but this is due to the fact that one of the duplicate cultures sometimes lagged a day behind the other but with the same pattern (as represented in Figure 20 ).

Increasing the copper concentration from a $\mathrm{pCu}^{*}$ of 15.4 to 14.4 generally stimulated cells and gave an increase in cell division (Figure 21). Further increases in ionic copper above pCu* of 14.4 were inhibitory and decreased the rate of cell division. These effects are most apparent during the first week of growth and are particularly dramatic by day 7 (Figure 22). Figure 22 again demonstrates the typical dcse-response relationship mentioned in Chapter I (Figure 1) where low concentration of a metal ion enhances a physiological process but a higher concentration becomes inhibitory and eventually toxic.

Once sexual reproduction begins in a batch culture, the growth rate, defined in terms of cell number over time, slows as shown in Figure 17. This slow down is in part attributed to the stationary phase and in part to induction 


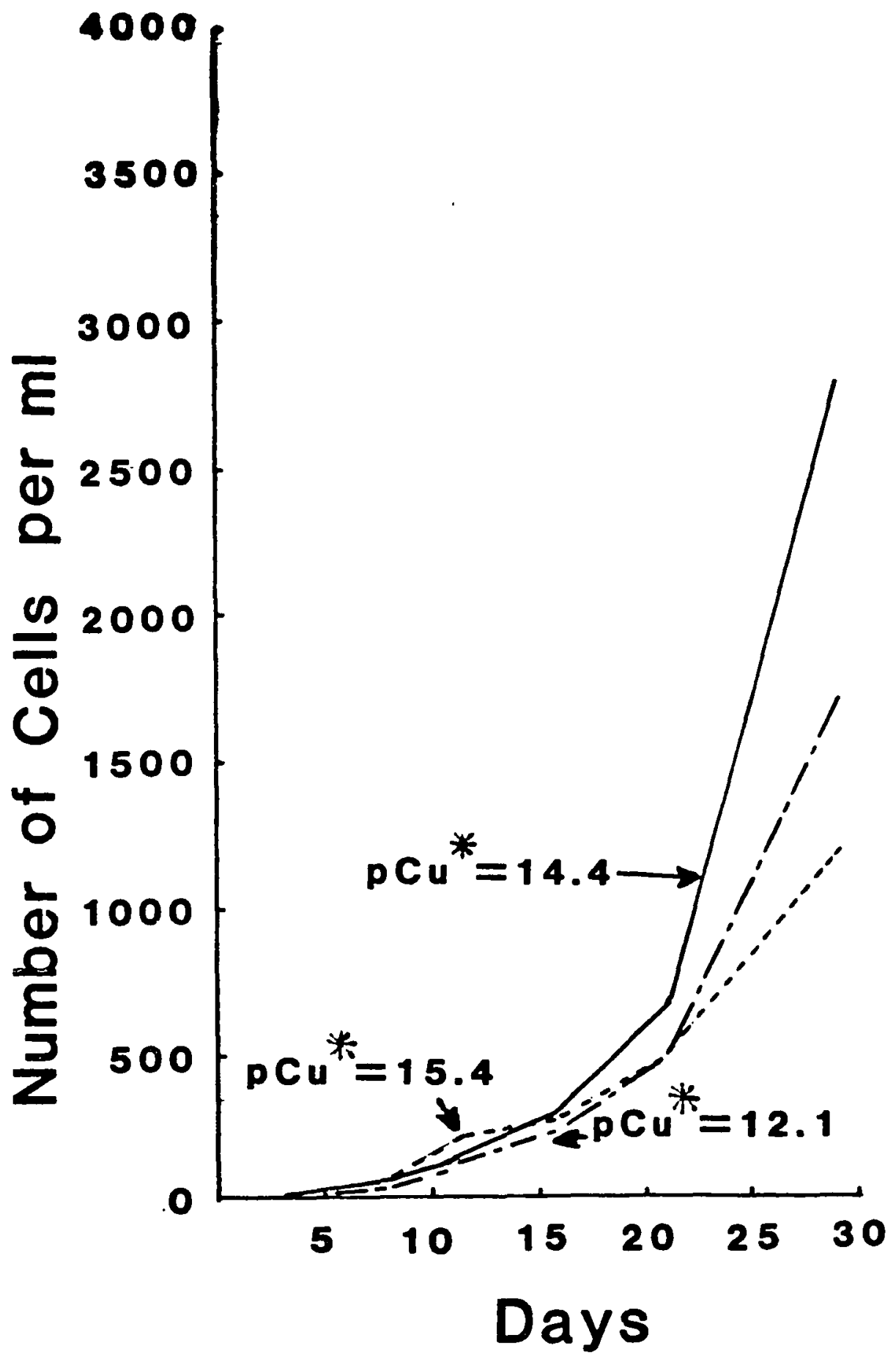

Figure 18. Number of cells per ml of strain 171 of Closterium moniliferum vs. time. The addition of small amounts of copper did not inhibit growth; the final cell density was highest at $\mathrm{pCu}^{\star} 14.4$. 


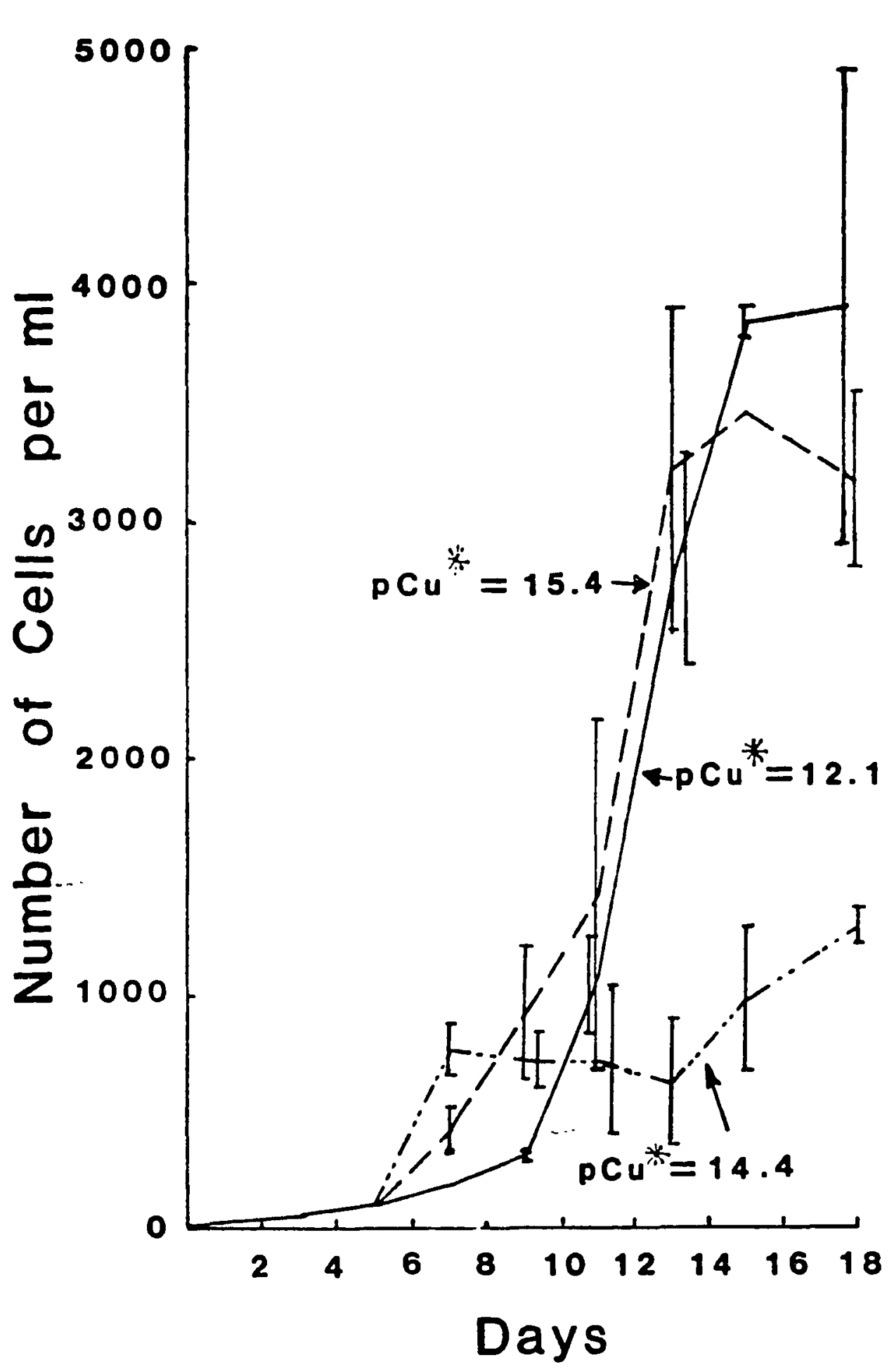

Fiqure 19. Number of cells per $\mathrm{ml}$ vs. time (days) in strain 96 of Closterium moniliferum. Error bars represent duplicate cultures. 


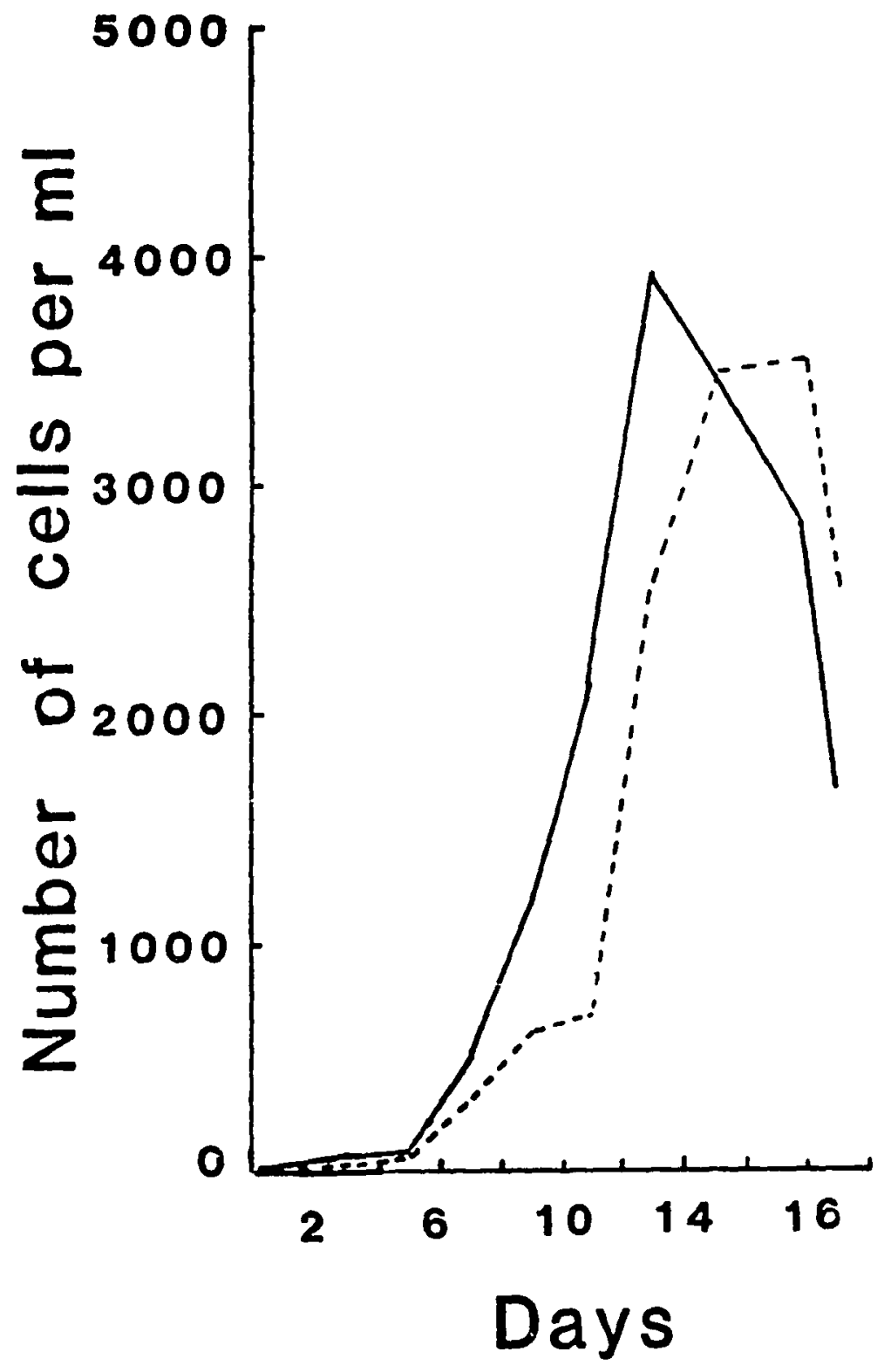

Figure 20. Number of cells per $\mathrm{ml}$ vs. time (days) instrain 96 of Closterium moniliferium. Duplicate cultures @ $\mathrm{pCu}^{*}=15.4$. 


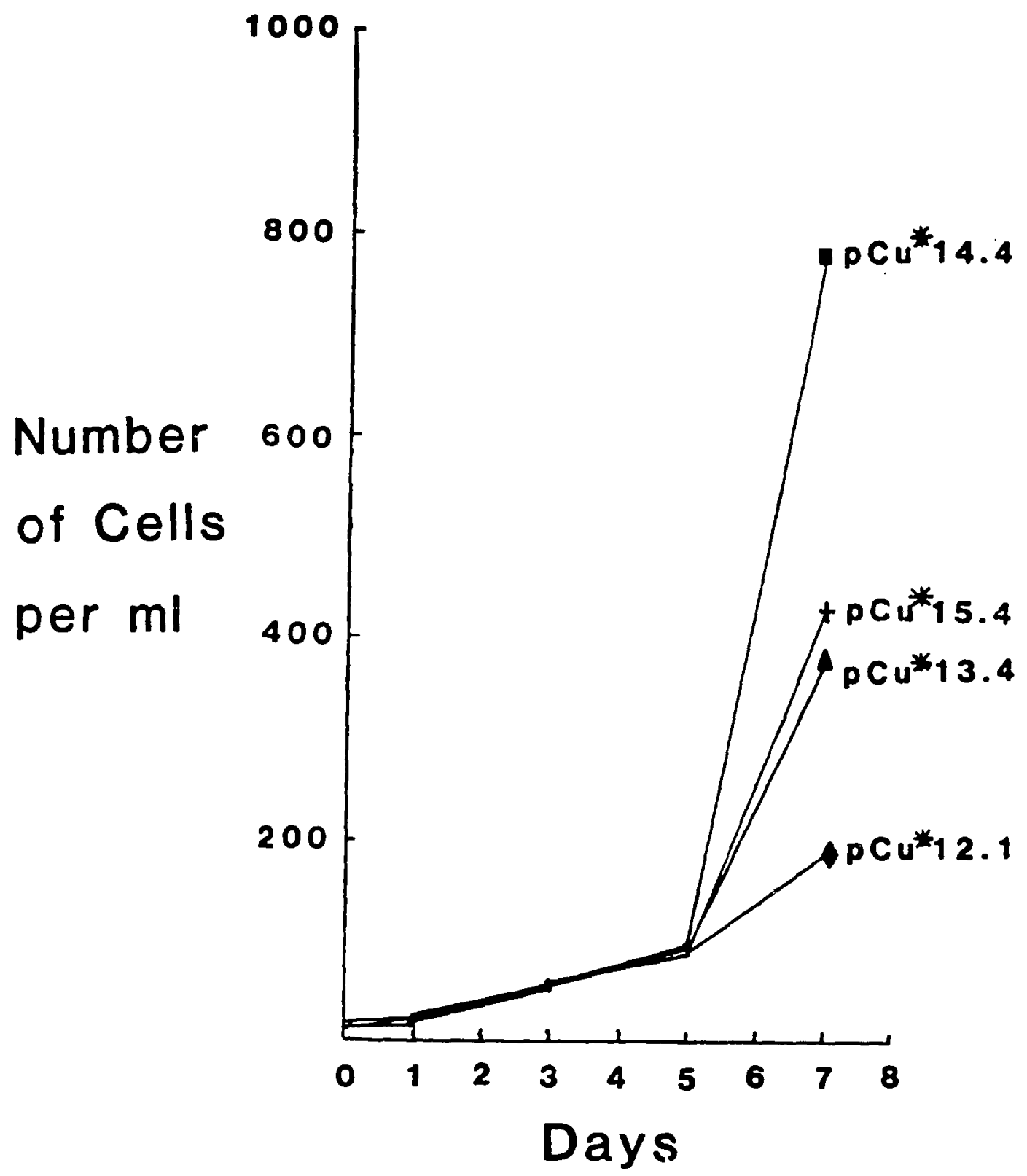

Fiqure 21. Number of cells vs. time (days) in strain 96 of closterium moniliferum. This demonstrates the typical dose-response of an organism to a trace metal. Cell growth was stimulated with the addition of small amount of copper but became inhibited at greater copper activities. 


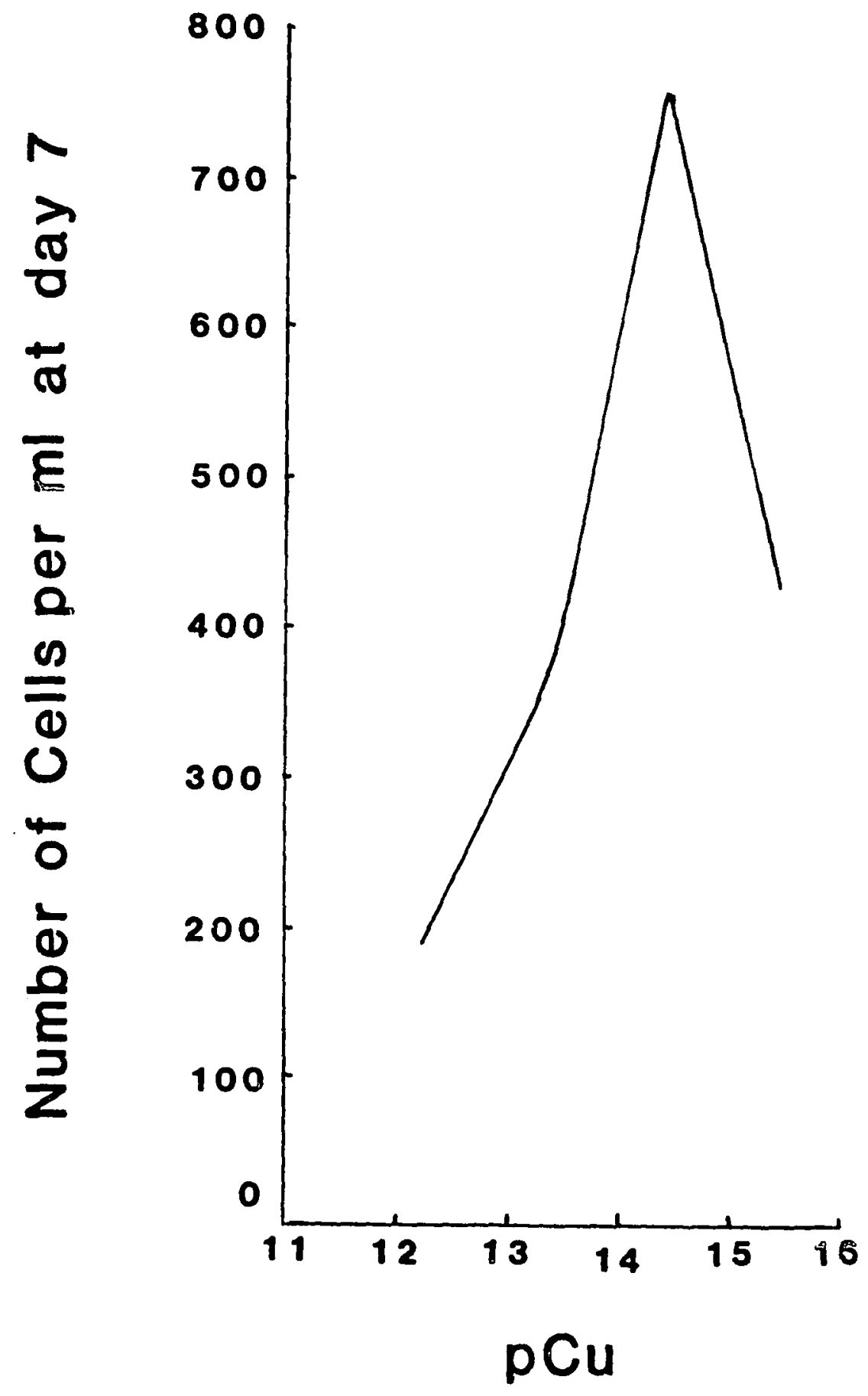

Figure 22. Number of cells per $m l$ at day 7 vs. pCu* in strain 96 of Closterium moniliferum. Small additions of copper appear to be stimulatory while larger amounts become inhibitory. This is expected from the suggested dose-response of organisms to trace metals (see Figure 1). 
of sex precluding vegetative cell division in any given pair of cells.

The stimulation of cell division at $\mathrm{pCu}^{*} 14.4$ varied in different experiments, (e.g. Figure 16 versus Figure 17), suggesting a narrow range where stimulation can occur or possible contamination of a sensitive system. The lengthening of the lag phase at $\mathrm{pCu} * 12.2$ was reproducible in both strains however. When stimulation of cell division occurred, nitrate uptake increased and sexual reproduction occurred earlier.

The longer lag phase evident at low $\mathrm{pCu}^{*}$ is a result of fewer cell divisions, but it has not been determined if this occurs because copper is acting on the cell division process itself or because copper affects nutrient uptake. Nutrient uptake inhibition in turn slows growth since cells must reach a minimum size before cell division can occur. Conversely, slower growth could slow nutrient uptake.

\section{Growth Rate}

Closterium moniliferum cells are unicellular and are rather large (maximum size of one strain used was 214 micrometers in length); therefore, they do not have a particularly rapid metabolism or growth rate. Calculating the growth rate is complicated because of the occurrence of sexual reproduction occurring. Once zygotes begin to be formed, those cells involved as gametes do not divide vegetatively so cell number decreases or at least cell number increase is slowed. 
Within the first days of these growth experiments, no sexual reprodiction is involved but the lag phase is included so growth rate would be low in all cases. Calculating the growth rate during different stages of the growth curve does show that cultures treated at $\mathrm{pCu} * 12.1 \mathrm{can}$ reach an equivalent growth rate and maximum cell number as cultures at $\mathrm{pCu}^{*} 15.4$ (Table III). The specific growth rate was computed using natural $\log \left(\log _{e} 2\right)$ so the rate corresponds to the number of divisions per day.

The growth rate and final cell densities again suggest adaptability to the presence of added copper. Steemann Nielsen and Kamp-Nielsen (1970) reported that normal growth rates were re-established in Chlorella pyrenoidosa after extended lag phases due to sub-lethal doses of copper. Work with toxic metals has generally shown decreased growth of algae (Sunda, 1975; Sunda and Guillard, 1976; and Jensen et al., 1976). Sunda (1975) reported that the specific growth rate was a function of $\mathrm{pCu}$ and Morel et al. (1978) found a prolonged lag phase in their work with skeletonema costatum. The work here shows the prolonged lag phase due to copper's effect as well as the re-establishment of the normal growth rate.

In looking for a genetic change to copper tolerance, Darling (1979) expected that cells would grow better when subcultured at the same pcu. However, he found that subcultures of Selenastrum capricornutum had a lower specific 


\begin{tabular}{lrrr}
\multicolumn{5}{c}{ TABLE III } & \\
& SPECIFIC & GROWTH & RATE $\left(\right.$ DAY $\left.^{-1}\right)$ \\
pCu* & DAYS & DAYS & $\mu_{\max }$ \\
& $1-7$ & $8-13$ & .76 \\
15.4 & .46 & .32 & 1.4 \\
14.4 & .55 & .08 & .80 \\
13.4 & .44 & .36 & .75 \\
12.1 & .35 & .54 &
\end{tabular}


growth rate. He postulated, then, that the lower growth rate may have been due to an increase in internal copper concentration or the accumulation of copper on the outside of the cell wall preventing cell division as suggested by Steemann Nielsen and Wium-Andersen (1970). The lag phase shown here may be due to this action of copper.

\section{Cell Division and Morphology}

In 1950, Hughes reported that copper interfered with the process of mitosis at prophase and the work of Kanazawa and Kanazawa with Chlorella (1969) showed that cell division was inhibited by copper at cytokinesis. Further research since then indicates that this effect of copper is a rather general phenomenon. The fact that copper affects cell division is particularly important here because cell division and sexual reproduction are closely linked in the strains of $\underline{c}$. moniliferum studied. Sexual reproduction takes place before vegetative cells mature, so cell division must occur shortly before sexual reproduction begins.

In Closterium moniliferum, cell division is definitely blocked by copper. In Closterium, cells normally separate when immature and non-symmetrical. Since sexual reproduction in these strains only occurs between immature cells, sexual reproduction is also blocked. When cells are exposed to copper, ( $\left.\mathrm{pCu}^{*} 12\right)$ light micrographs (Figures 23-27) and scanning electronc micrographs (Figures 28-30) show mature cells still joined together. 

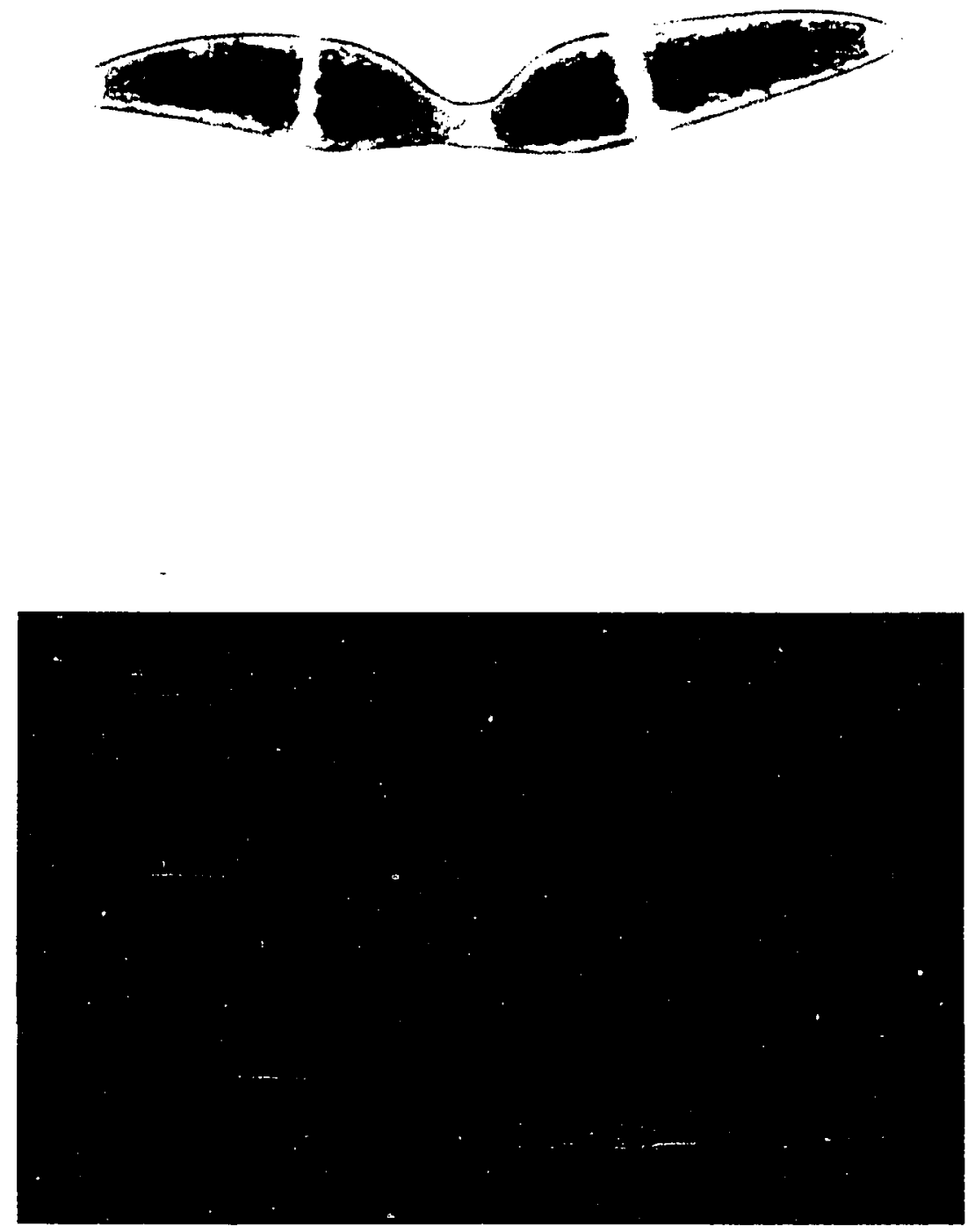

Figures 23 and 24. Strain 96 of Closterium moniliferum. Cells unseparated after treatment with copper. LM $430 \mathrm{X}$. 

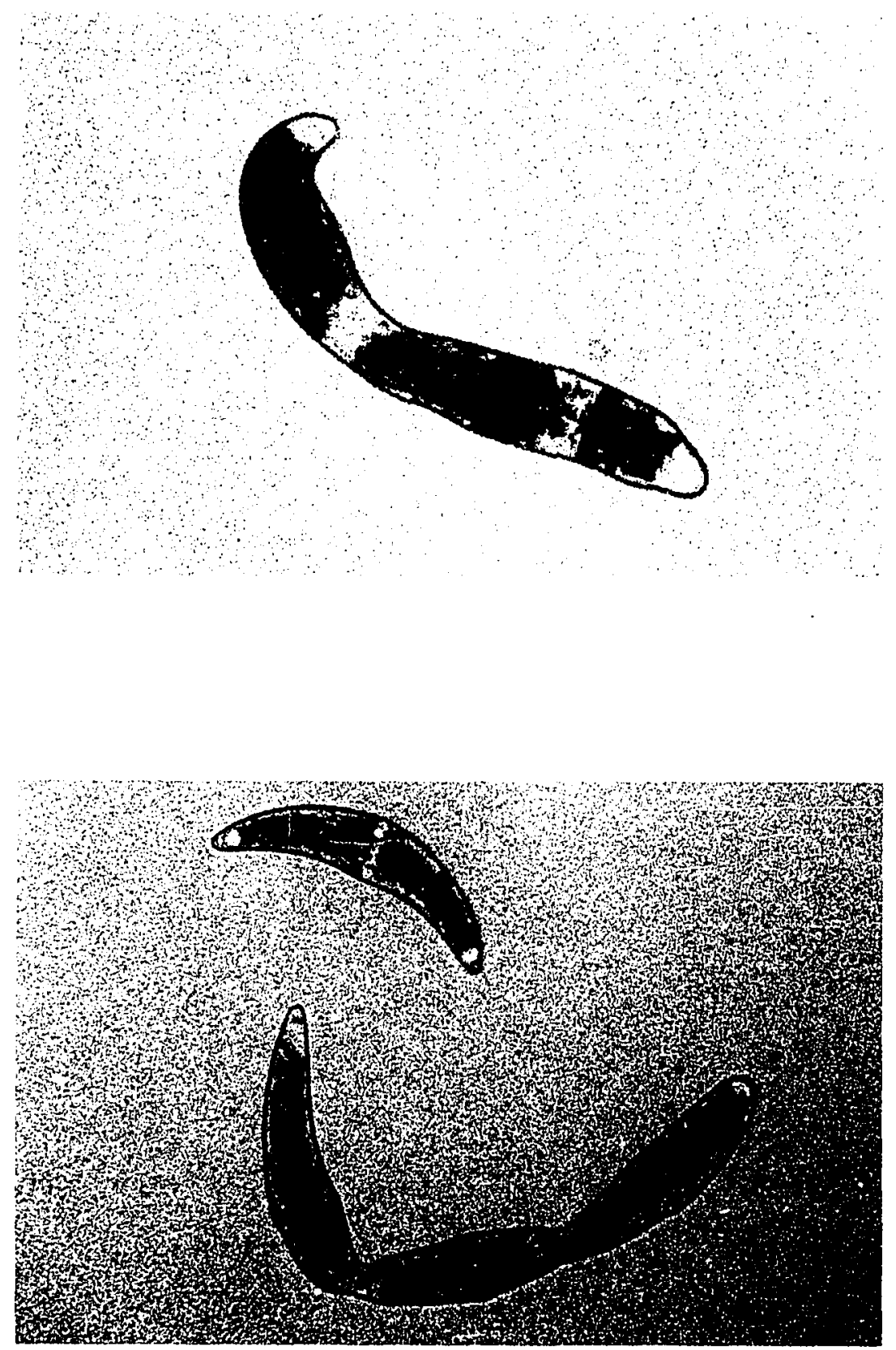

Figures 25 and 26. Strain 96 of Closterium moniliferum. Celis unseparated after treatment with copper. LM $430 \mathrm{X}$. 


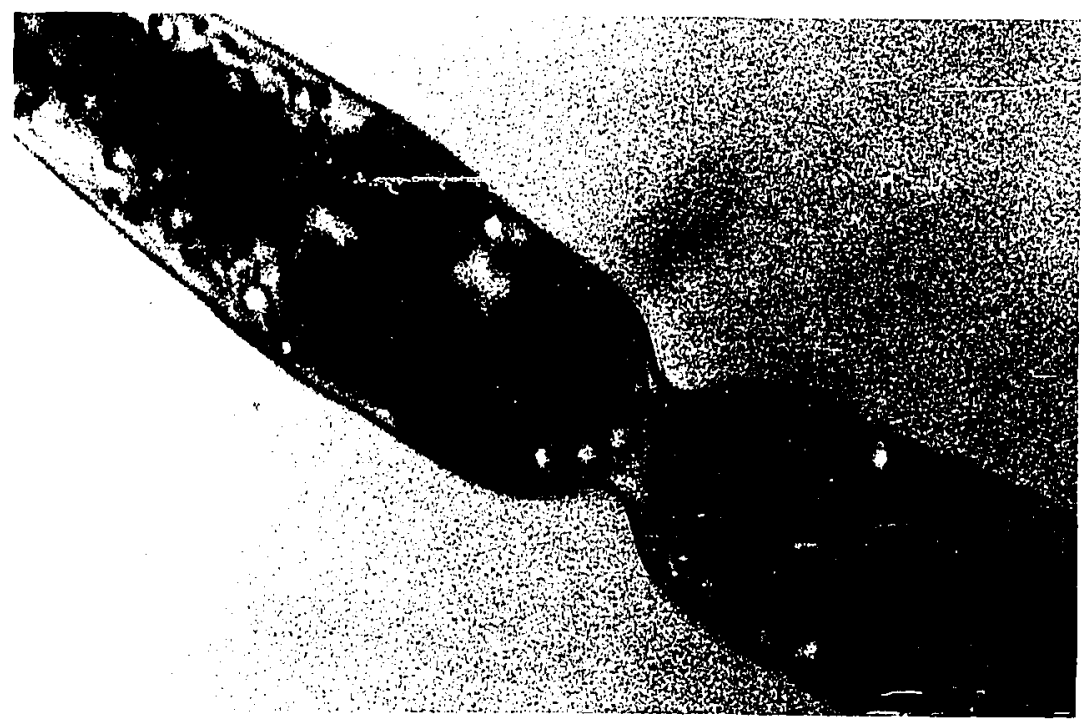

Figure 27. Strain 96 of Closterium moniliferum. Englargment of unseparated cells after treatment with copper. LM approximately $800 \mathrm{X}$. 


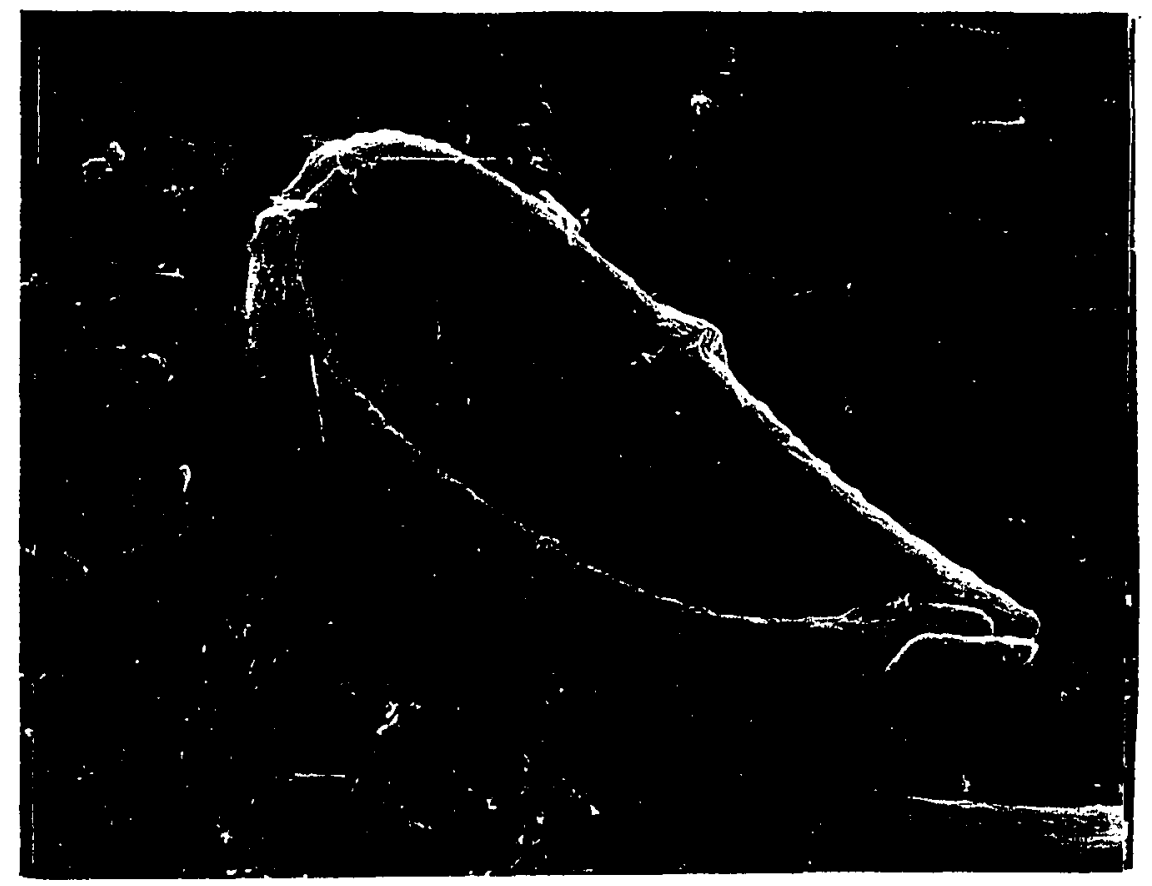

Figure 28. Strain 96 of Closterium moniliferum. Cells unseparated after treatment with copper. SEM $500 \mathrm{X}$. 



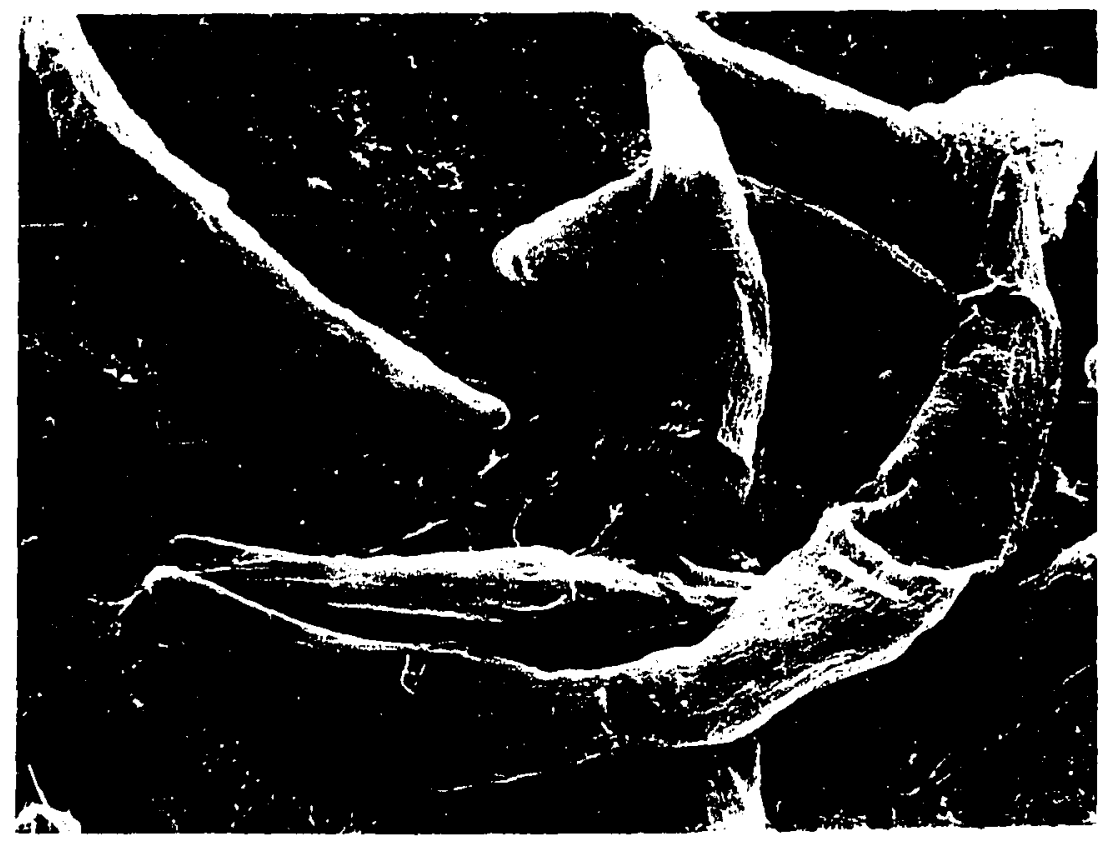

Figure 30. Strain 96 of Closterium moniliferum. Cells unseparated after treatment with copper. SEM $500 \mathrm{X}$. 
Another morphological effect that results from uncoupling of cell growth and cell division is abnormal cells. It is improbable that these distorted aberrant cells (Figures 12 and 31-34) would be able to divide; if this is so, it would further decrease the growth rate and the ability to have sexual reproduction. The scanning electron micrograph of Figure 31 illustrates the old semi-cell that is normal and the new semi-cell that results from abnormal growth. The cell shown in Figure 32 indicates that the abnormal semi-cell may be able to divide to give a totally distorted cell with no normal morphology evident. This would also indicate that mitosis is not the process affected by excess copper.

Kiermayer (1970) in his work with the desmids Cosmarium and Micrasterias found that cell wall deposition continued in the absence or interruption of cell expansion and most significantly, that the new wall material was deposited in a predetermined pattern. The accumulation of wall material at any region may be related to whether that particular region of wall would have continued to expand under normal circunstances.

Kiermayer also found that if cells were prevented from undergoing any expansion at all after cytokinesis, the septum itself developed a pattern of uneven wall thickening, again related to the potential form of the expanding semi-cell. This appears to be the effect (Figures 33 and $34)$ in closterium treated with copper. 


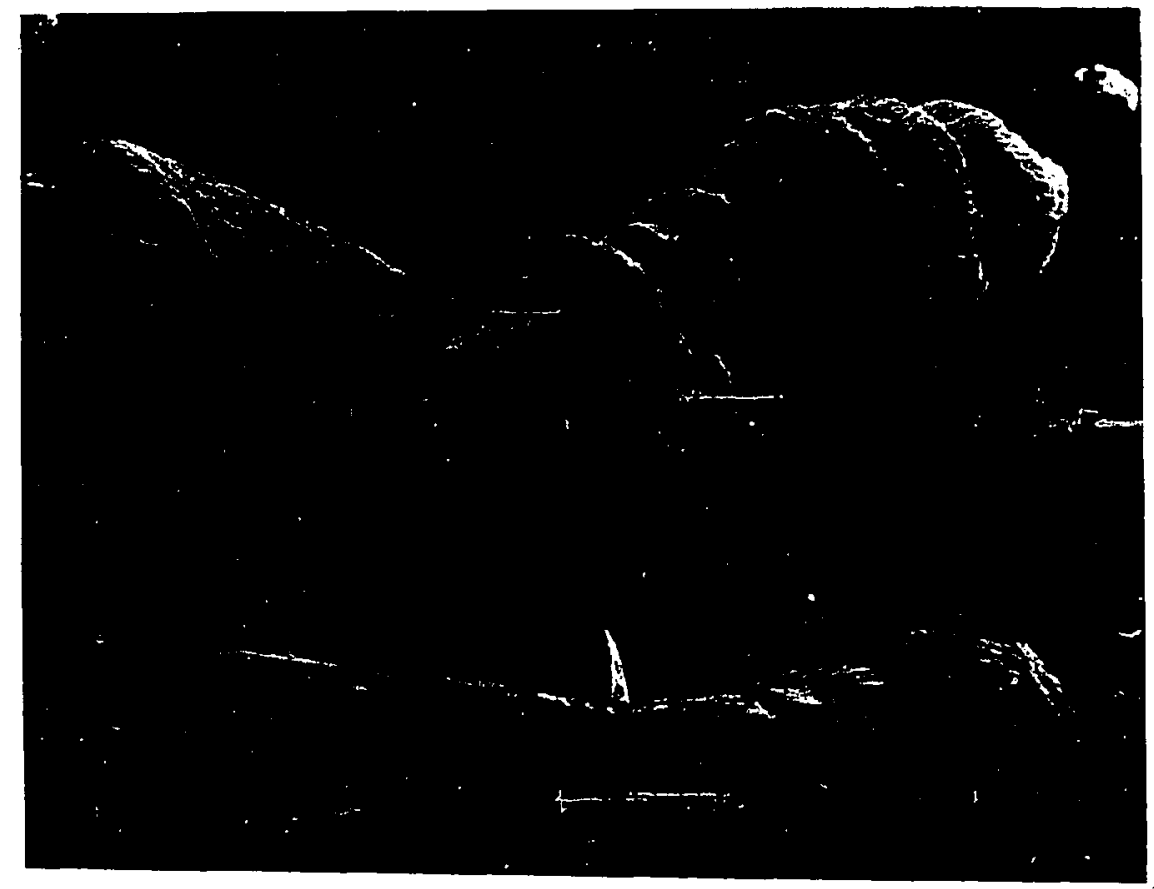

Figure 31. Strain 96 of Closterium moniliferum. Note how the new semi-cel is distorted and does not give a symmetrical appearance. SEM $500 \mathrm{X}$. 


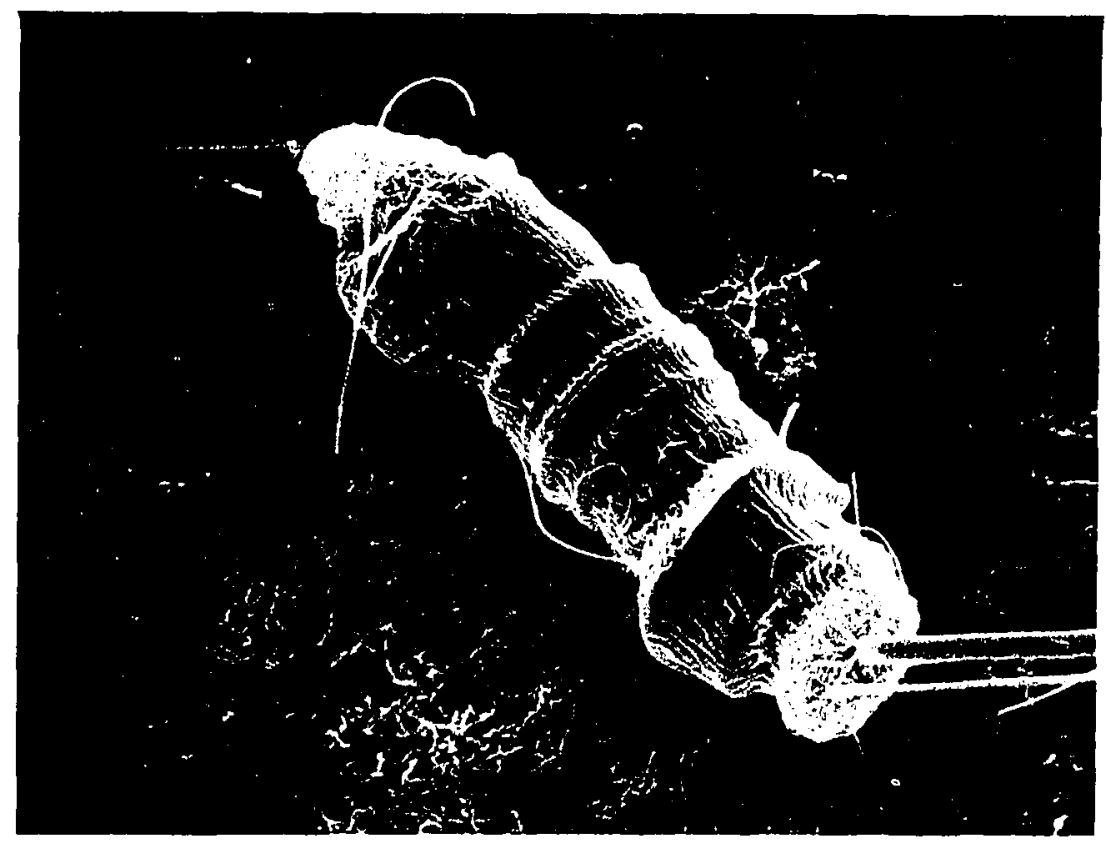

$\frac{\text { Figure } 32}{\text { SEM } 500 \mathrm{X}}$. Abnormal cell of Closterium moniliferum. 

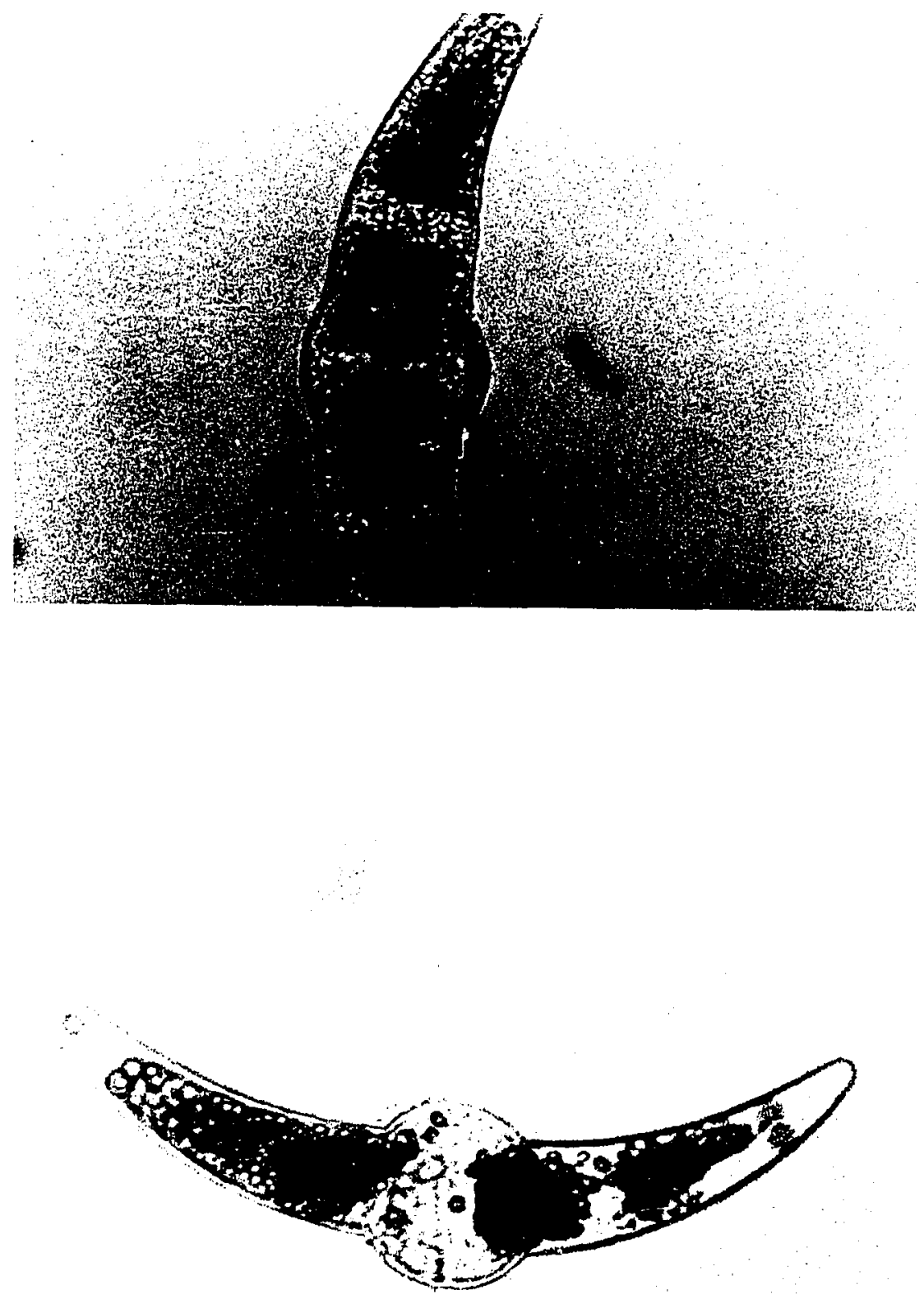

Figures 33 and 34 . Strain 96 of Closterium moniliferum. Cells that have been treated with copper. Note the distorted cell shape particularly the bulbous shape at the isthmus. LM $430 \mathrm{x}$. 
Chlorophyll Content as a Function of Copper

The total amount of chlorophyll as produced by a population of cells was decreased when the cells were in the presence of increased copper. Although the total amount of chlorophyll produced in 48 hours was less in those populations treated with more copper, the cells also did not divide so chlorophyll/cell was higher (Table IV). Copper may have affected cell division directly or the effect may have been indirect by less chlorophyll production and therefore less photosynthesis and energy production.

14 Carbon Uptake as a Function of Copper

The amount of ${ }^{14}$ carbon taken up per cell was decreased when cells were in the presence of increased copper $\left(p C u^{*} 5.5\right)$. Cells without excess copper had nearly twice the assimilation ratio minute ${ }^{-1} \mathrm{mg}$ chlorophy $1 \mathrm{l}^{-1}$.

\section{CONCLUSION}

A toxic sublethal amount of copper causes an increased lag phase, which can eventually be overcome with the culture reaching a normal growth rate. This suggests adaptability of the organisms to the presence of copper. Smaller amounts of copper may be stimulatory to growth and beneficial to the organisms as suggested by the dose-response of physiological processes to metal ions.

Cell division was definitely inhibited by the addition of excess copper to batch cultures of Closterium 
TABLE IV

AMOUNT OF CHLOROPHYLL/CELL AS A FUNCTION OF pCu*

$\mathrm{pCu} *$

15.4

14.4

12.1 mg chlorophyll/cell before treatment

$6.2 \times 10^{-4}$

$6.8 \times 10^{-4}$

$6.3 \times 10^{-4}$ mg chlorophyll/cell 48 hours after copper was added

$7.9 \times 10^{-4}$

$12 \times 10^{-4}$

$12 \times 10^{-4}$ 
moniliferum. Evidence for this is the growth patterns at different $\mathrm{pCu}^{*}$, with the longest lag phase at $\mathrm{pCu}$ * 12.1 . Light micrographs and scanning electron micrographs show distorted and unseparated cells which indicate copper affects cell wall deposition or mitosis. Inhibition of either of these processes would increase the lag phase. The evidence for adaptability is presented both in the growth patterns and in the specific growth rates. After an increased lag phase, the cultures growing at low pCu* were able to overcome the toxic effects and reach a growth rate equal to that at a higher $\mathrm{pCu}$.

The initial decreased growth rate could be due to a number of processes. Nutrient uptake may be inhibited and therefore slow growth. It is unlikely that chlorophyll production is the limiting factor since chlorophyll/cell remains high with reduced cell division. The micrographs suggest uncoupling of growth and cell division. The effect could be on the cell's outer surface or on the cell membrane. Chapter IV addresses the uptake of nitrogen in growth experiments and Chapter $\mathrm{V}$ addresses other morphological changes. 
CHAPTER IV

INHIBITION OF NITROGEN METABOLISM BY EXCESS COPPER

INTRODUCTION

Growth rate has been shown to be a function of the intracellular concentration of the macronutrients of silicon (Paasche, 1973), phosphorus (Fuhs, 1969), and nitrogen (Caperon and Mayer, $1972 \mathrm{a}$ and $\mathrm{b}$ ). The toxic effect of metals (in this work copper) and the limitation of macronutrients (in this work nitrogen) interact to affect the total metabolism of the cell.

The life cycle of Closterium moniliferum is influenced by its external environment in the media and in natural waters. Depletion of nitrate in the media caused populations of strain \#96 of closterium moniliferum to begin sexual reproduction. Thus, if the trace metal copper acts on the nitrogen metabolism of closterium, it could have an ultimate effect on the inducement of the sexual stage of the life cycle.

Since both cell division and nitrate depletion are necessary for sexual reproduction, the hypothesis proposed was that with fewer opportunities for cell division and inhibited nitrate uptake due to the effect of copper, there would be less or delayed sexual reproduction at a lower 
$\mathrm{pCu}$. This hypothesis was generally found to be true. The exception was where copper appeared to be stimulatory in its effect on cell division and nitrate uptake ( $\left.\mathrm{pCu}^{*}=14.4\right)$ which ultimately led to more frequent and earlier sexual reproduction.

This chapter examines long term ( 3 week) and short term (48 hours) nitrate uptake and the timing of the onset of sexual reproduction as a result of changes in the rate of uptake due to added copper. Rate of zygote germination and abortions are also examined.

\section{RESULTS AND DISCUSSION}

In this work, copper inhibited uptake of nitrate. When this uptake was delayed, sexual reproduction was delayed. Previously, (1977) Harrison et al. showed that copper inhibited nitrate uptake and the activity of the assimilatory enzyme, nitrate reductase, in natural algal populations. This action of copper on the nitrogen metabolism could affect sexual reproduction here in closterium, but it is also probable (Chapter III) that sexual reproduction may also be affected by copper acting on the process of cell division itself.

\section{Nitrate Uptake in Long Term Experiments}

Most evidence points to the membrane as the primary site of copper toxicity (Rothstein, 1959). This indicates that nutrient uptake could be the primary process affected. 
Although the uptake of many nutrients could be affected by added copper, nitrate was chosen to be the measured parameter because of its close relationship with sexual reproduction in desmids (which was demonstrated by Biebel in 1964) and shown in my early work with closterium moniliferum.

Nitrate uptake experiments confirmed the inhibition of nitrate at low $\mathrm{pCu}^{*}$ and the stimulation at $\mathrm{pCu}^{*} 14.4$ with strain \#96. When $\mathrm{pCu}^{*}=14.4$, uptake of nitrate (Figure 35) was more rapid than at $\mathrm{pCu}^{*}$ of $12.1,13.4$, or 15.4, resulting in a medium depleted of nitrate earlier in the experiment. This apparent stimulation of nitrate uptake and subsequent early sexual reproduction must be sensitive because not all repeat experiments showed these results. This may be due to a slight difference in $\mathrm{pCu}$ due to autoclaving of the media in the first experiments, to different general cell conditions, or to contamination of a sensitive system. Inhibited nitrate uptake at the lower $\mathrm{pCu}$ * was reproducible however.

At $\mathrm{pCu}^{*} 12.1$, inhibition of nitrate uptake delayed the onset of sexual reproduction whereas stimulation at pCu* 14.4 caused early sexual reproduction in strain \#96 (Figure 36). The number of cells per milliliter at the time of onset of sexual reproduction was not a critical factor.

Strain \#171 did not display this expected nitrate depletion before sexual reproduction. Other researchers 


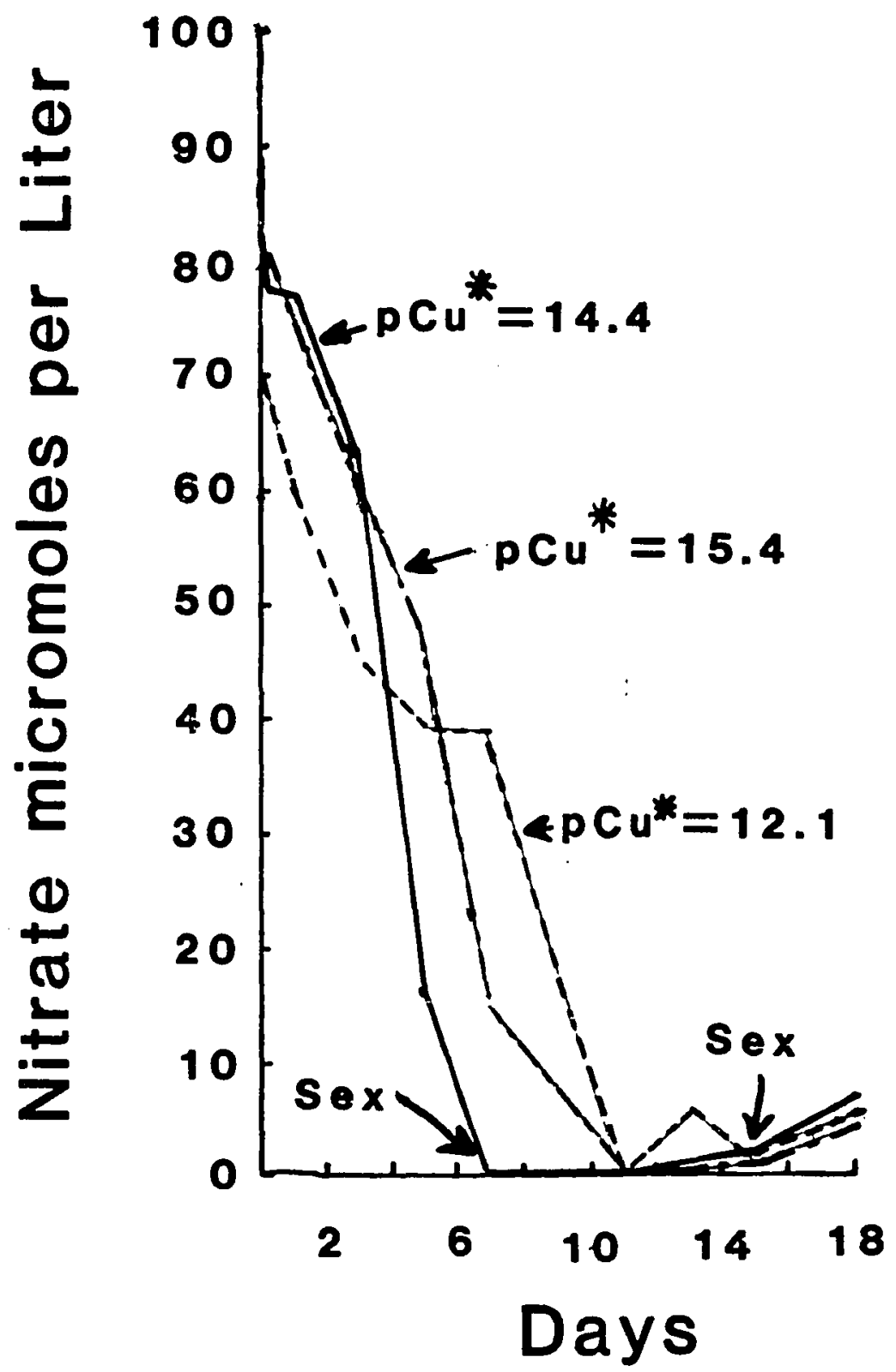

Figure 35. Nitrate remaining in the medium vs. time (Days). Sexual reproduction occurred when nitrate was depleted in strain 96 of Closterium moniliferum. 


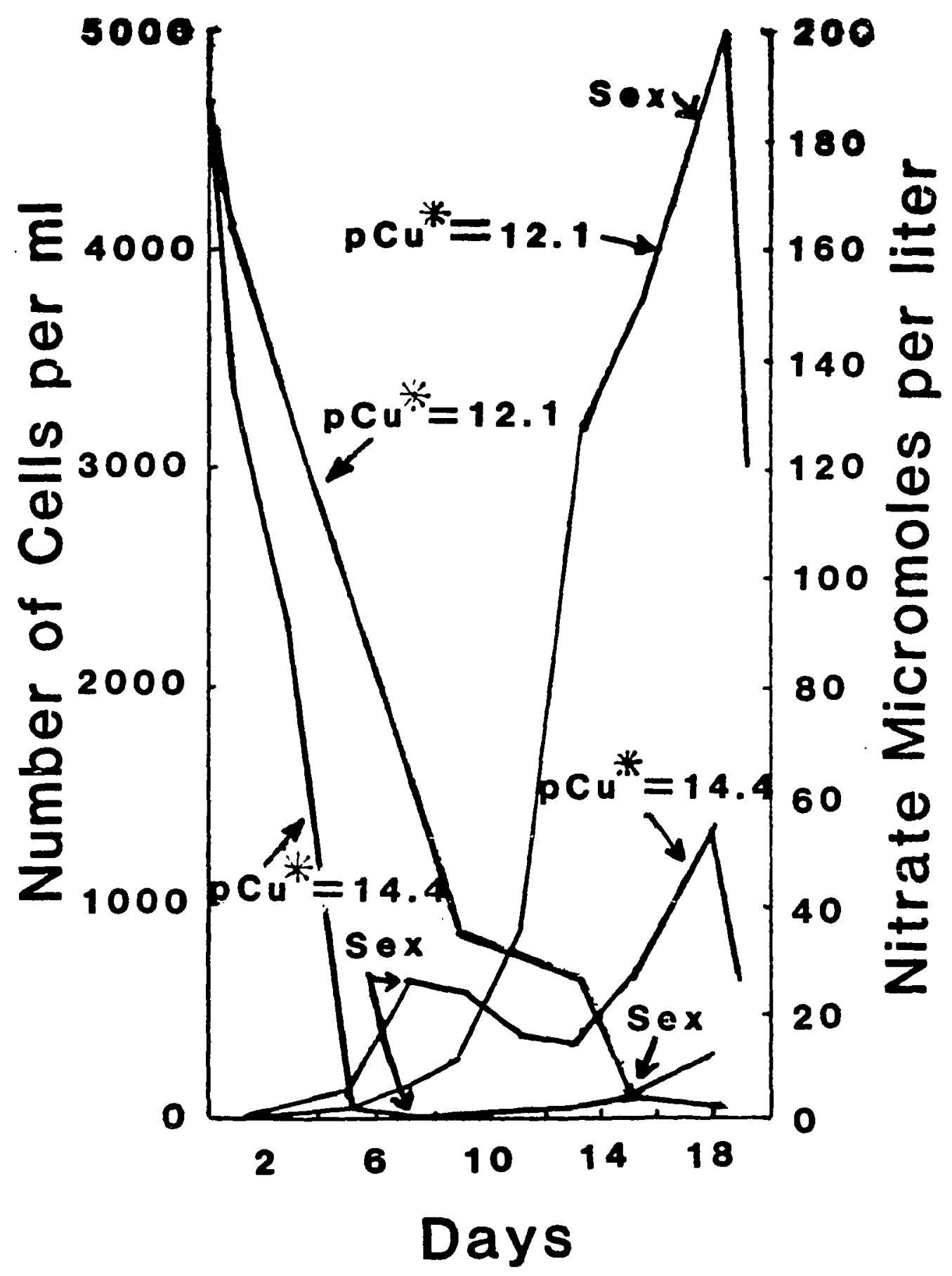

Figure 36. Cell number and nitrate uptake vs. days. Note the correlation between nitrate depletion and onset of sexual reproduction. 
working with closterium sp. did not find it essential for the nutrient medium to be nitrogen-deficient for sexual reproduction to occur. Enhanced carbon dioxide supply induced conjugation (Starr, 1955; Dubois-Tylski and Lacoste, 1970; and Lippert, 1973), although Lippert (1969) found greater $\mathrm{CO}_{2}(10 \%)$ increased cell lysing and abortion rate. Although strains \#I7l and \#96 are both in the $\underline{C}$. moniliferum group, the reason that their responses may be different is that one of them (\#171) may be mis-classified (Lippert, personal communication).

\section{Nitrate Quota}

This research was approached with the hypothesis that cells would enter the sexual reproduction phase of the life cycle when the nitrogen cell quota became critical (minimal) within the cell. It was thought that copper might inhibit nitrate uptake and thereby decrease the amount of nitrogen in each cell which would lead to sexual reproduction. This was not found to be the case. With sub-lethal concentrations of copper added, nitrate uptake was not completely prevented. At pCu* 12.1 nitrate uptake in strain \#96 was inhibited and sexual reproduction was delayed until nitrate was depleted in the medium. In the beginning of the experiment, cells at $\mathrm{pCu} * 12.1$ had large nitrogen quotas because nitrate uptake continued while cell division was slowed. When sexual reproduction occurred, however, cell quota of nitrate was as low as those cells growing at $\mathrm{pCu}$ * 15.4 (Table V). 
TABLE V

NITROGEN QUOTA AND ONSET OF SEXUAL REPRODUCTION AS A FUNCTION

OF COPPER

$\mathrm{pCu}$ *

Day of Nitrate

Depletion

12

6

11

13
Day of Sexual
Reproduction

14

8

13

14
N Quota at time of sex (micromoles)

12.1

${ }^{*} \mathrm{~N}$ Quota $=\frac{\text { micromoles } \mathrm{NO}_{3} \text { taken from the medium }}{\# \text { of cells }+2(\# \text { of zygotes }+ \text { aborted cells })}$ 
It is apparent, however, that minimum cell quota is not the factor affecting the onset of sexual reproduction since sexual reproduction occurred earlier when nitrate uptake was rapid $\left(\mathrm{pCu}^{*} 14.4\right)$ and cell numbers were low; these cells had a high cell quota at the time of sexual reproduction. Also, in earlier experiments with strain \#96, sexual reproduction occurred sooner when beginning nitrate concentrations were less (Figure 37 ). Q, the nitrate quota, was high in these cells when early sexual reproduction occurred.

Although Eppley (1978) reported nitrate uptake kinetics depend on the concentration of nitrate in the medium and . nitrogen cell quota, this work with Closterium showed sexual reproduction to be a function of the depletion of nitrate in the medium, not nitrogen cell quota.

Onset of Sexual Reproduction in Strain 96

Sexual reproduction in this strain occurred shortly after nitrate depletion of the media (Table V) and was not dependent on cell number (Figures 36 and 37). When copper stimulated cell division and nitrate uptake (populations at $\mathrm{pCu}^{\star}$ 14.4), sexual reproduction occurred earlier than in populations without added copper. Both sexual reproduction and nitrate uptake were delayed at pCu* 12.1.

It is reasonable to assume that if the FRAQUIL medium had less nitrogen, sexual reproduction would occur earlier. This was found to be true experimentally (Table VI). It 


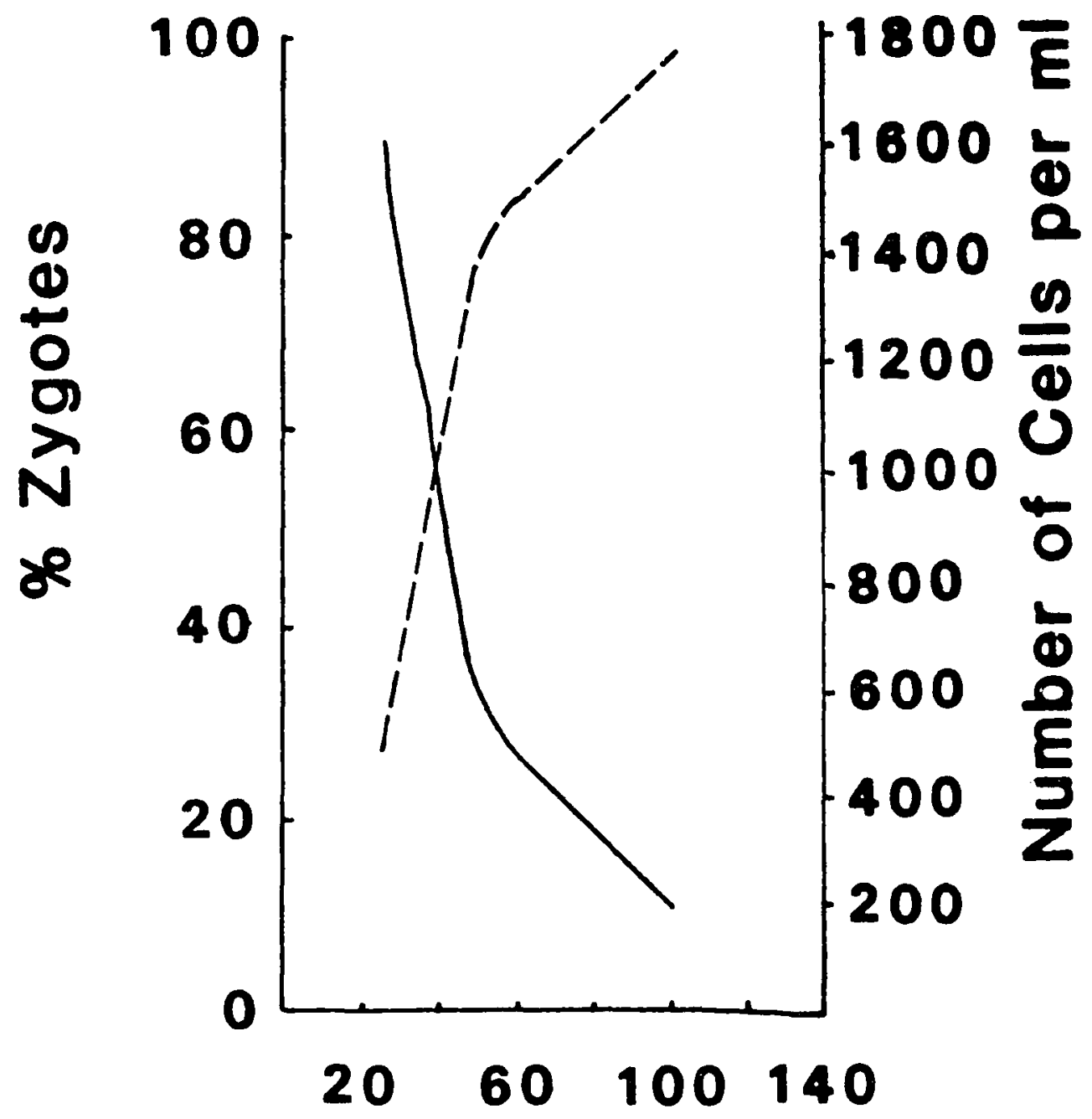

\section{Nitrate Concentration}

\section{micromoles per llter}

Figure 37. Number of zygotes per total cell number $\mathrm{X} 100$ vs. initial concentration of nitrate.

Total number of cells per $\mathrm{ml}$ at the time of sexual reproduction vs. initial concentration of nitrate. 
TABLE VI
ONSET OF SEXUAL REPRODUCTION AS A FUNCTION
OF BEGINNING NITRATE
$\left(\mathrm{pCu}^{*}=15.4\right)$

\section{Nitrate Concentration \\ At Beginning of \\ Growth Experiment (micromoles/liter)}

25

50

100

200

$$
\text { Onset of }
$$

Sexual

Reproduction

(Days)

7

9

16

16
Maximum

Cell Number

(per $\mathrm{ml}$ )

430

1000

3230

6100 
is interesting to note that when sexual reproduction occurred early in a culture, due to beginning nitrogen limitation (Figure 37), the percent of culture undergoing sexual reproduction was greater than in those with larger cell number and later sex. The percent of culture undergoing sexual reproduction was calculated:

s Sexual Reproduction $=\frac{2(\# \text { Zygotes }+\# \text { Abortions })}{\text { Cell } \#+2(\# \text { Zygotes }+\# \text { Abortions })}$

Although the populations stimulated by copper $(\mathrm{pCu} *=14.4)$ had higher frequency of sexual reproduction early in the growth curve (Figure 38 ), the populations at other pCu* values were able to achieve as high a frequency later. This again indicates the cells can adapt to the presence of copper and overcome its effects.

Although it is difficult to quantify, an effect of copper on sexual reproduction, independent of nitrate, may be inferred by the morphology of copper treated cells. At day 7 of the long-term experiment, $11.2 \%$ of the cells in the population were aberrant at $\mathrm{pCu}^{*} 12.1$ compared to less than 18 at $\mathrm{pCu}^{*} 15.4$ (Table VII). Aberrant cells include cells that are distorted (Figures 31-34), unseparated in the process of cell division (Figures 23-30), with less chlorophyll than normal (Figures 39-42) or with many vacuoles (Figures 43 and 44 )). It is assumed that these aberrant cells are unlikely to be able to initiate or complete the process of cell division (which must precede sexual reproduction). 


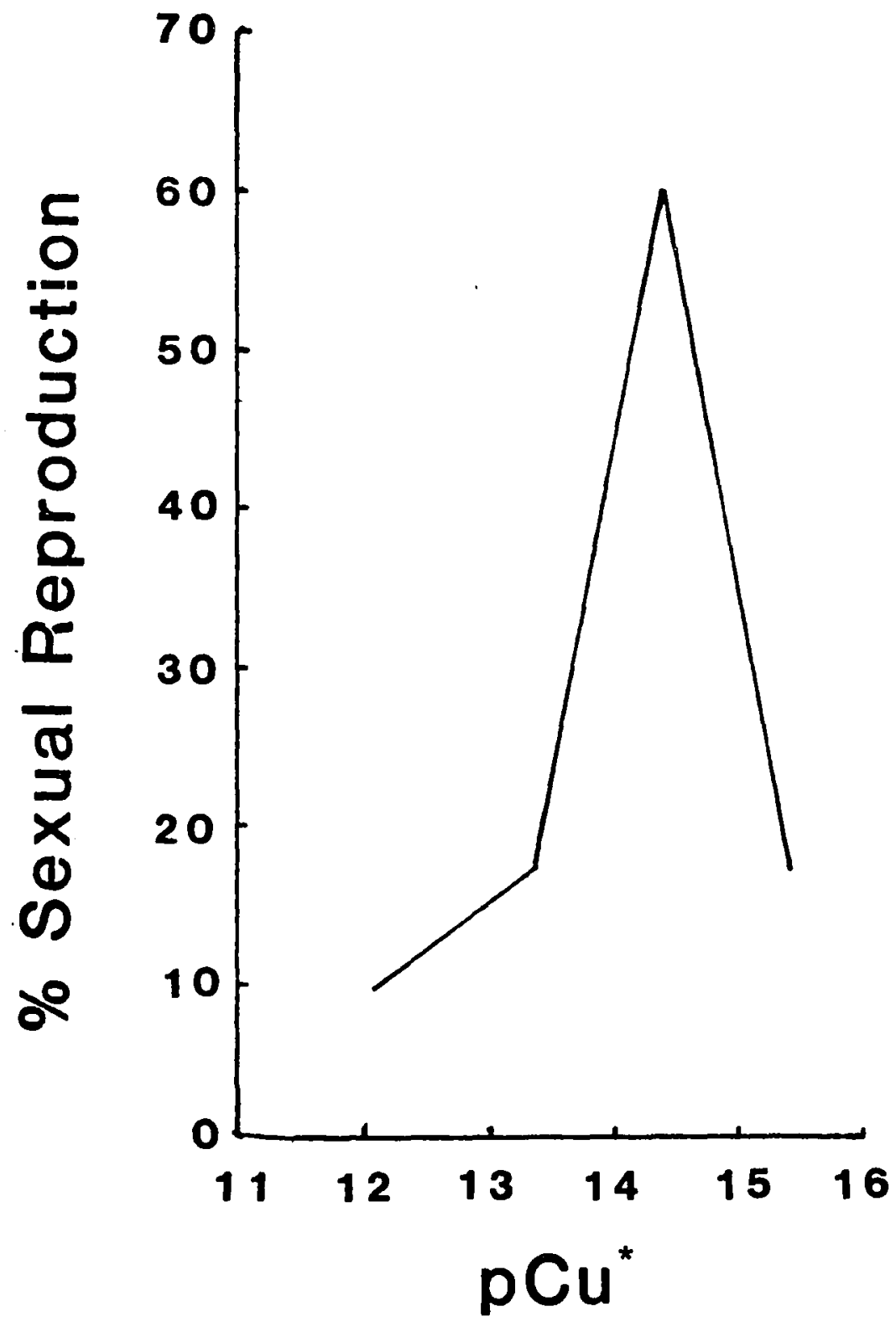

Figure 38. Percent sexual reproduction a day 15 of the growth curve vs. pCu*. 
TABLE VII

$\begin{array}{cc}\text { PERCENT ABERRANT CELLS } \\ \text { pCu* } & \text { Day 7 } \\ 15.4 & 0.95 \% \\ 14.4 & 1.5 \% \\ 13.4 & 3.7 \% \\ 12.1 & 11.2 \%\end{array}$




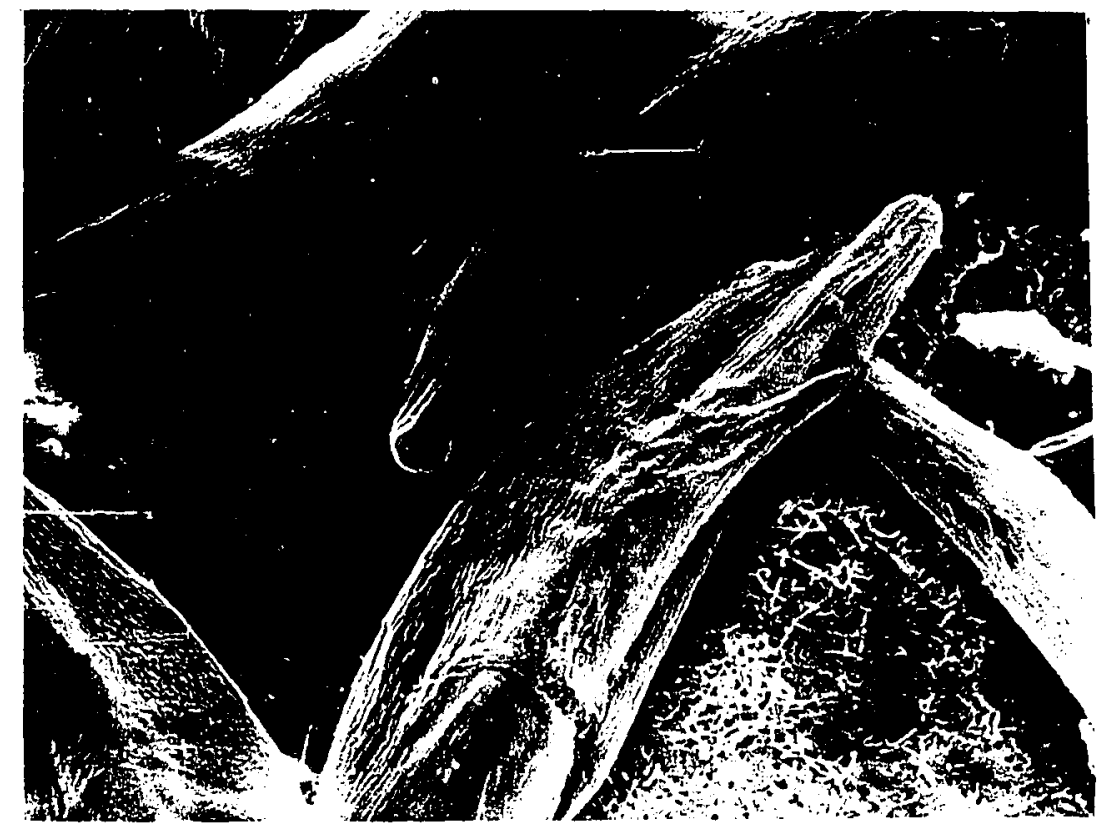

Figure 39. Strain 96 of Closterium moniliferum. This scanning electron micrograph shows evidence of a shrunken protoplast inside the cell. SEM $500 \mathrm{X}$.

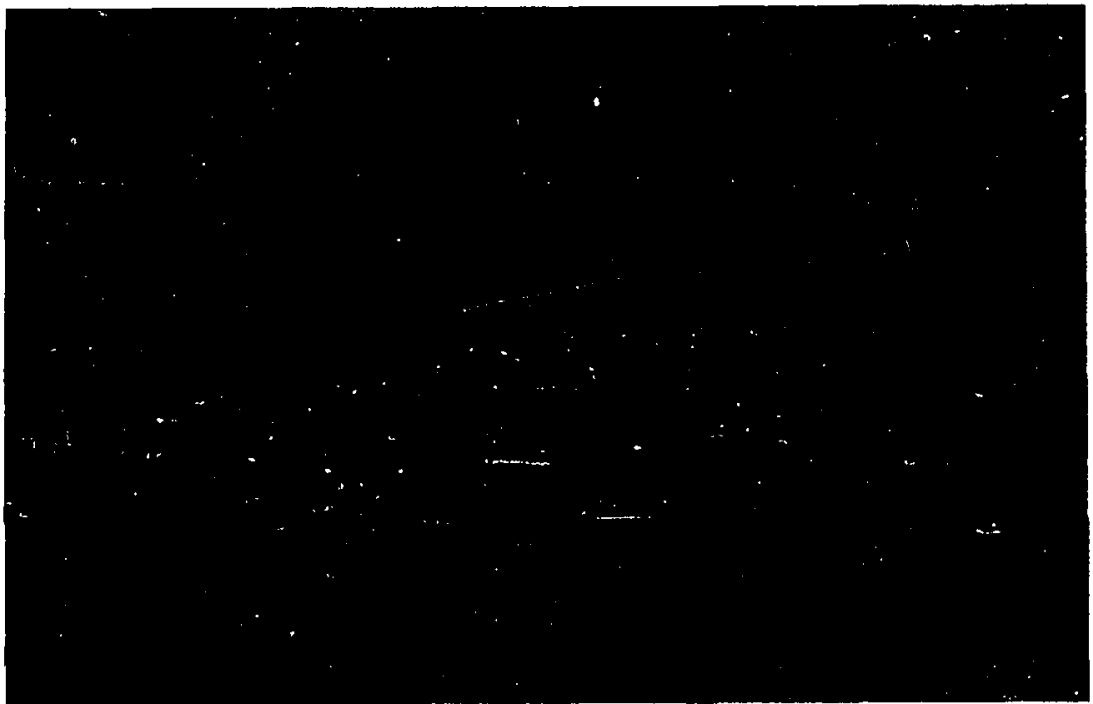

Figure 40. Strain 96 of Closterium moniliferum. Cell with less than normal amount of chlorophyli and with protoplast pulled away from the cell wall. LM $430 \mathrm{X}$. 

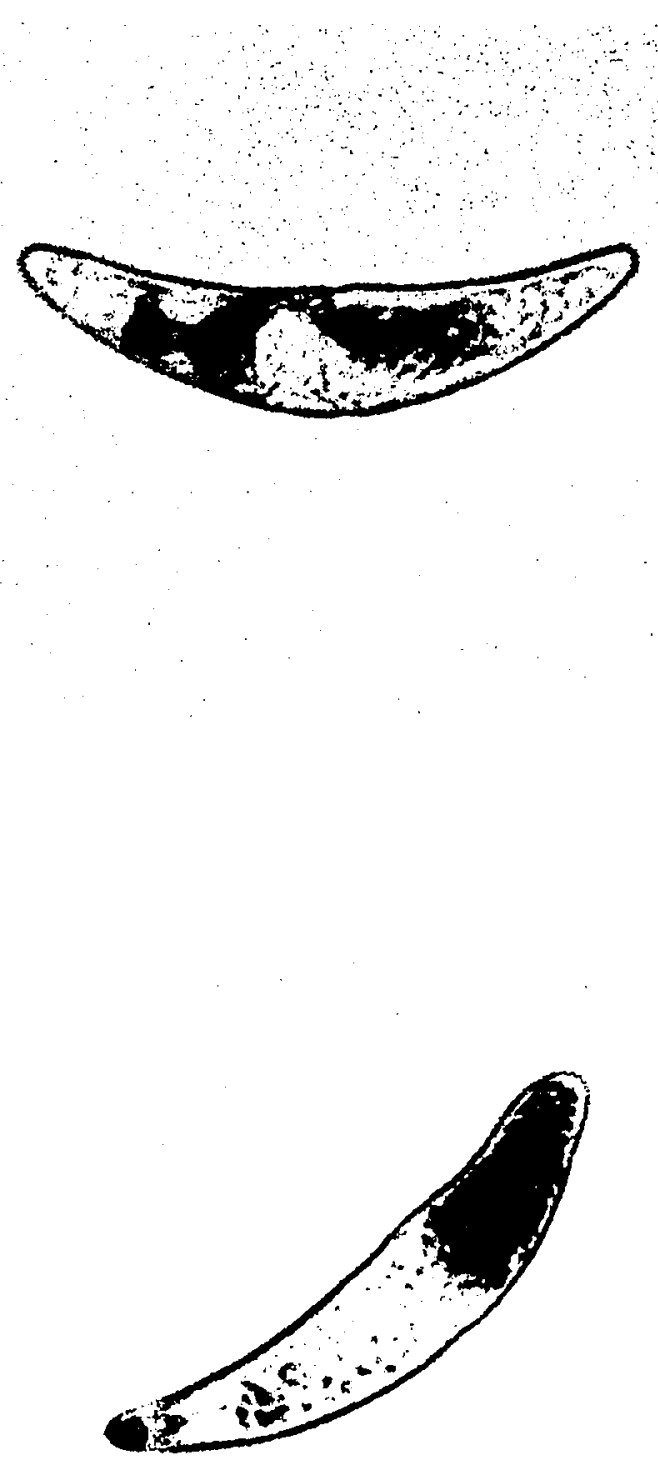

Figures 41 and 42 . Strain 96 of Closterium moniliferum treated with copper. These cells are examples of cells that were treated with copper and had less chlorophyll per cell than those cells that did not have extra copper added to the medium. LM $200 \mathrm{X}$. 


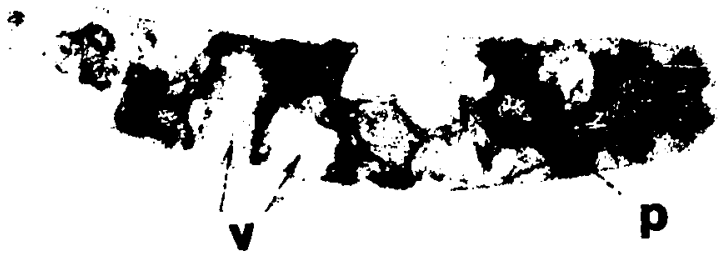

Figure 43. Strain 96 of Closterium moniliferum. This cell demonstrates the presence of large vacuoles formed throughout the cell when added copper is in the medium. $\mathrm{p}=$ pyrenoid; $\mathrm{v}=$ vacuole. LM $430 \mathrm{X}$.

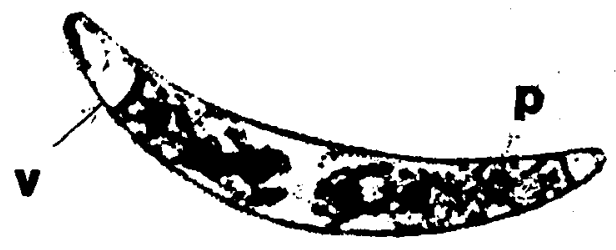

Figure 44. Strain 96 of closterium moniliferum. This result is seen in some cells in the presence of added copper. $p$ = pyrenoid; $v$ = vacuole. LM $600 \mathrm{x}$. 
Onset of Sexual Reproduction in Strain 171

Sexual reproduction was not correlated with nitrate depletion in this strain. Sexual reproduction began when nitrate was in adequate supply and cell numbers were very small (less than $100 / \mathrm{ml}$ ). Other researchers have induced conjugation in Closterium without nitrogen depletion (Starr, 1955; Dubois-Tylski and Lacoste, 1970; Lippert, 1973); they stressed the importance of an enchanced $\mathrm{CO}_{2}$ supply. Pickett-Heaps and Fowke (1971), however, did not find an increased $\mathrm{CO}_{2}$ supply a prerequisite for conjugation in Closterium Iittorale. As pointed out by Coesel (1974), conjugation would seem to occur most readily when illumination, temperature and $\mathrm{CO}_{2}$ tension are at an optimum for mitotic activity. This would seem to be particularly true in these strains of Closterium moniliferum where sexual reproduction takes place between newly divided immature cells.

\section{Zygote Germination}

There was no significant difference in the percent germination in cultures at any $\mathrm{pCu}^{*}$ when copper was added to cells when in their vegetative asexual stage. When copper was added to mature cultures at the same time as light and nutrients required for germination, again there was no significant difference in percent germination.

It may be beneficial for populations to begin sexual reproduction when copper is present in the environment since 
evidence shows growing cells are susceptible. The thickwalled zygotes may act as a survival stage for the organism. During the maturation process, the zygote may provide protection. In a natural environment, the time needed for maturation may be enough time for dilution of the toxicants to occur so vegetative cells could survive. Research here has shown that toxic amounts of copper present do not prevent germination; newly formed vegetative cells are subject to the toxic effect.

Added copper does not appear to have any effect on the germination of closterium moniliferum. The germination process was not inhibited but the newly formed products of germination were killed by a low $\mathrm{pCu}^{\star}$.

\section{Abortions}

Although preliminary experiments indicated that with increased zygote production, there was also increased abortion rate, subsequent experiments did not substantiate this. The percent of abortions varied from 1 to $25 \%$ of the zygotes formed and did not correlate with $\mathrm{pCu}^{*}$ or nitrate in the medium.

\section{Nitrate Uptake in Short Term Experiments}

The effects of copper on nitrate uptake were analyzed by nitrate depletion in cultures over short time intervals from 2 to 69 hours. In nearly all cases, nitrate uptake was most rapid when no added copper was present. The most rapid uptake occurred in the first 5 hours after nitrate 
was added to the nitrogen-depleted cultures with an average uptake rate (without added copper present) of $7.27 \times 10^{-4}$ micromoles nitrate cell-1 hour-1. The maximum during that five hour period without added copper in any one experiment was $22 \times 10^{-4}$ micromoles cell-1 hour-1 and the minimum was less than $1 \times 10^{-4}$ micromole $\operatorname{cell}^{-1}$ hour-1.

The exception to the most rapid uptake occurring without copper being added was one experiment where added copper to give a final molarity of $10^{-7} \mathrm{M}$ caused a more rapid uptake of $5.1 \times 10^{-4}$ micromole cell-1 hour-1 vs. 4.7 micromole $\operatorname{cell}^{-1}$ hour $^{-1}$ (with no added copper) at the end of 22 hours. However, early in the experiment ( 5 hour sampling) the nitrate uptake rate was not as great with copper as it was without it. In this same experiment, added copper to give a final molarity of $5 \times 10^{-8} \mathrm{M}$ caused inhibition in comparison to the $10^{-7} \mathrm{M}$. This concentration of copper $\left(10^{-7} \mathrm{M}\right)$ could be analogous to the sensitive point ( $\left.p C u^{*} 14.4\right)$ in the long term experiments with strain 96 where uptake rate was increased and sexual reproduction occurred earlier. Generally, the lesser concentrations of copper exerted less toxicity in terms of $\mathrm{NO}_{3}$ uptake on the cells (Figure 45 ).

It was generally found that a decrease in nitrate uptake rate occurred over time (Table VIII) when no copper was added. After a rapid uptake in the beginning, there is a decrease, followed by a slight increase. At the very end of the experiments, this decrease may be due to the 


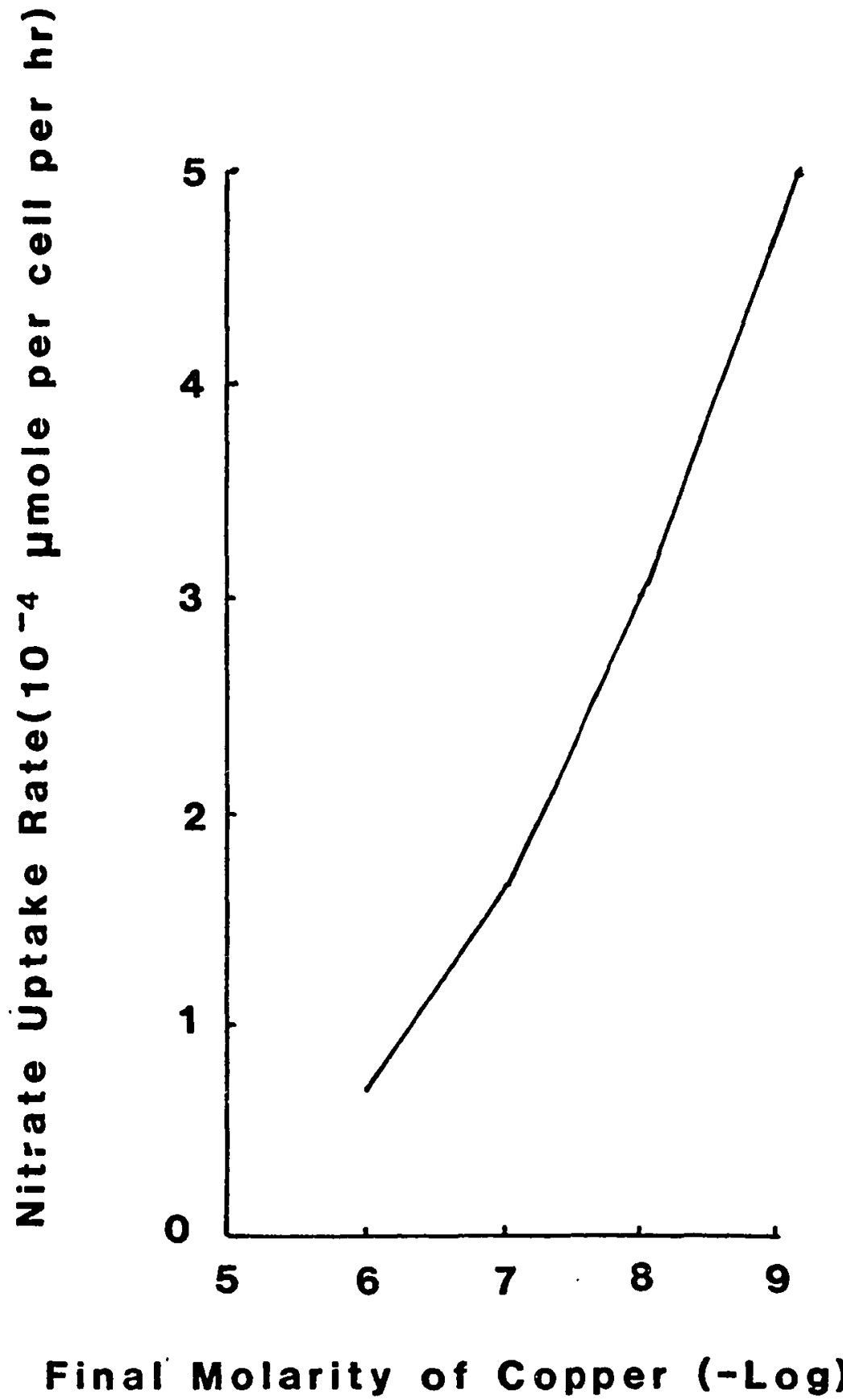

Figure 45. Nitrate uptake rate vs. final copper concentration. Time factor is 24 hours. TRIS buffer was present in the test media. 
TABLE VIII

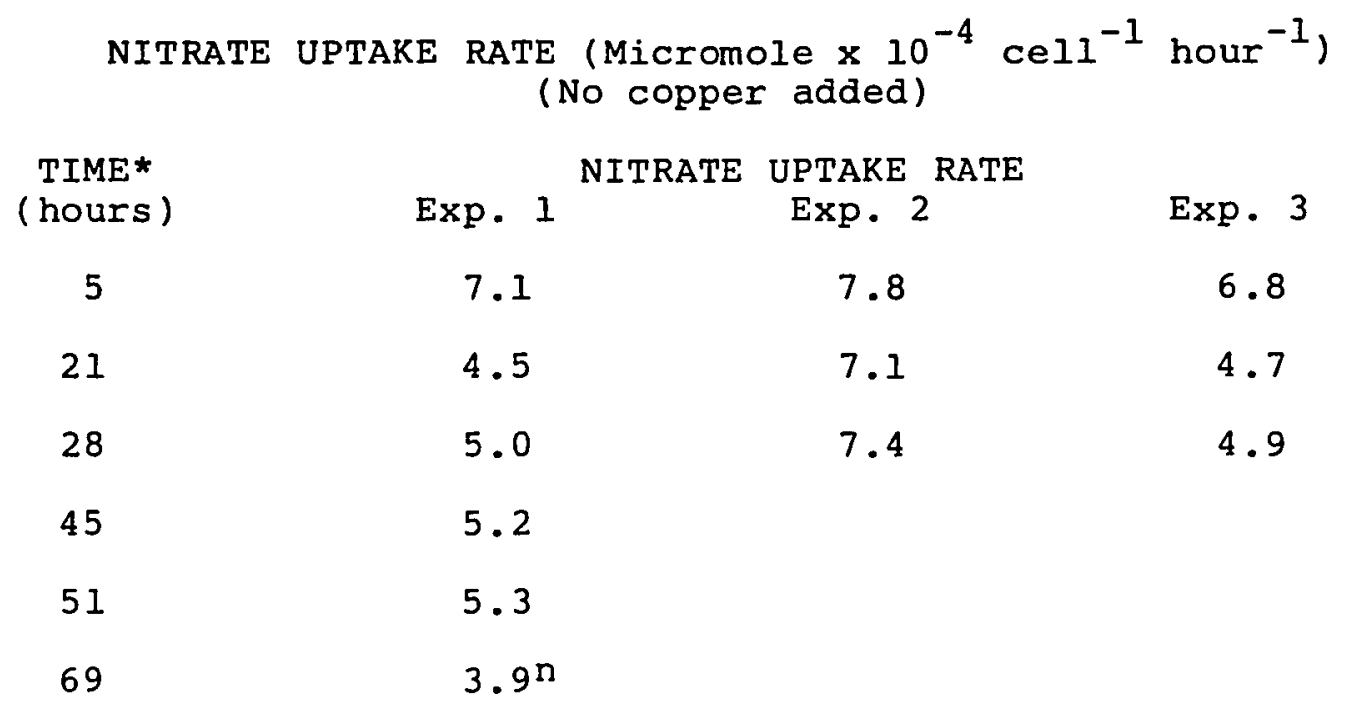

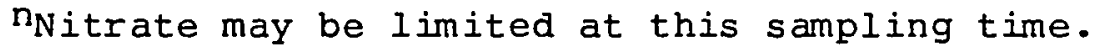


lack of nitrate availability, but through most of the experiment, nitrate was in adequate supply. In contrast, inhibition of nitrate uptake due to added copper generally lessened as the experiment proceeded (Table IX). Again, this demonstrates the adaptability of the organisms to the presence of copper.

The cells appear to be rapidly adaptable to the presence of copper since they are able to increase nitrate uptake rate after initial contact with the metal. Although lack of nitrate uptake sometimes occurred for up to 26 hours when sub-lethal concentrations of copper were added, these cells were subsequently able to take up nitrate. This adaptability may partially account for a lag in nitrate uptake rather than complete blockage. This may help explain why there is delayed nitrate depletion and delayed sexual reproduction characteristic of the effect of copper in long term experiments, rather than total blockage.

Examining nitrate uptake is an indrect way of examining the synthesis and activity of nitrate reductase since uptake is closely linked to the presence of nitrate reductase. Nitrate reductase is an inducible enzyme produced in the presence of nitrate so it is assumed that there is little or no nitrate reductase present in nitrogen depleted cultures. When nitrate was added to these nitrogen depleted cultures, copper was added at zero time to some flasks and 5 hours later to other flasks. Differences in uptake were not significant so it is not possible to say if synthesis 


\section{TABLE IX}

NITRATE UPTAKE RATE (Micromole $\times 10^{-4} \mathrm{cell}^{-1}$ hour $^{-1}$ ) AS A FUNCTION OF COPPER

TIME (hour)

FINAL MOLARITY OF COPPER

\begin{tabular}{cccc}
\multicolumn{5}{c}{ FINAL MOLARITY OF COPPER } \\
$9.9 \times 10^{-10}$ & $10^{-6}$ & $3.5 \times 10^{-6}$ & $7 \times 10^{-6}$ \\
7.8 & 4.0 & 0.6 & 0.6 \\
7.1 & 5.7 & 2.8 & 0.9 \\
7.4 & 6.0 & 2.3 & 1.5
\end{tabular}

*0 hour is the time nitrate and copper were added to nitrate depleted cultures. 
of nitrate reductase or activity is affected more by copper.

Ammonia Uptake in Long Term Experiments

To determine if copper equally affected all aspects of the nitrogen metabolism of Closterium moniliferum or if copper was more toxic to the process of nitrate uptake, long term growth experiments were run with ammonia and with nitrate as separate nitrogen sources.

A representation of nitrogen uptake and assimilation in unicellular organisms and possible sites of copper's action is shown in figure 46. Although nitrite is an intermediate in nitrate reduction, it is usually not considered to be a significant factor (Eppley and Rogers, 1970). If copper is acting on the uptake of nitrogen into the cell as well as cell division, the effects would be shown by different growth patterns when different nitrogen sources are used. If copper influences the amount of nitrogen taken into the cells, metabolism may be affected which may ultimately affect growth. Copper may have more than one site of action, acting both on cell division and nutrient uptake. Copper may specifically affect nitrate uptake which would slow the amount of nitrogen reduced to ammonia and ultimately available for incorporation, or copper may specifically affect ammonia uptake, directly affecting the amount of ammonia available. 


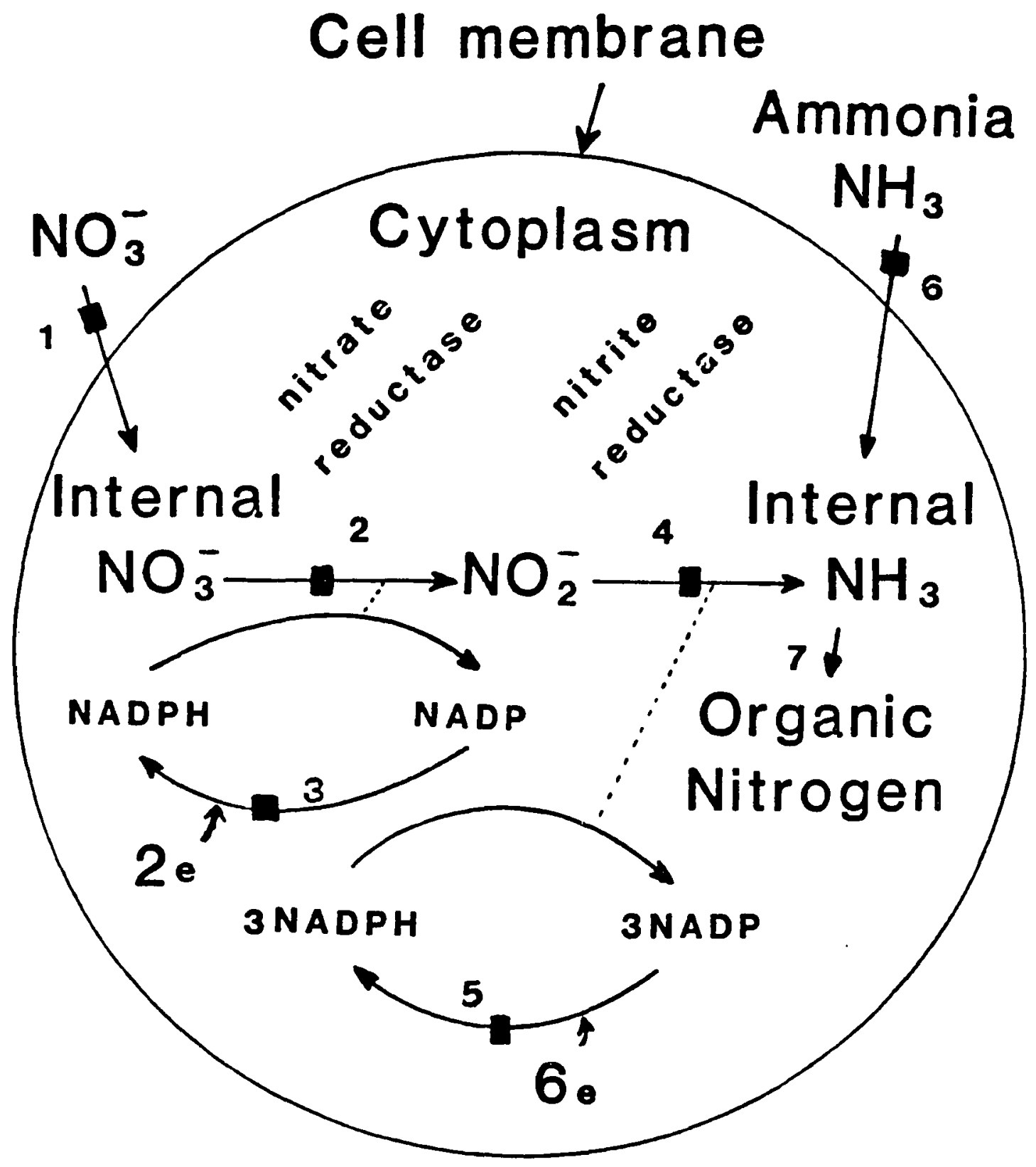

Fiqure 46. Metabolic sites that may be blocked by the action of copper. Copper may be acting on any of the 7 sites shown with a interrupting the arrow. 
With few exceptions, algae can apparently utilize either ammonium salts or nitrate when these are supplies at a suitable concentration. Some Chlamydomonas and Gloeocystis species (Cain, 1965) and Haematococcus (Proctor, 1957; Stross, 1963) prefer utilization of nitrate to ammonium. Nitrate reduction, however, requires energy, and if the energy supply is limited more growth will occur on ammonium-N (Lewin, 1962). In batch culture experiments, the presence of greater than micromolar levels of ammonium prevented the utilization of other nitrogen sources (Morris, 1974). Ammonium is known to both inhibit the activity of and repress the synthesis of nitrate reductase, thus preventing assimilation of nitrate (Hattori, 1962a,b); Morris and Syrett, 1963; Syrett and Morris, 1963).

The maximum inhibition by copper was seen when nitrate was the nitrogen source (Figure 47 ). The lag phase was prolonged and these cultures were never able to overcome the toxicity and attain the maximum cell density. The cultures with ammonium, with and without copper, were able to reach the same maximum cell number as those with nitrate and no copper. Cells grew slightly better (with the shortest lag phase) when nitrate was the nitrogen source and no added copper was present; this may have been due to the acclimatization of the cells since they had previously been grown in FRAQUIL with nitrate.

The fact that copper inhibits nitrate uptake indicates that the site of copper's action may be the inducible enzyme 


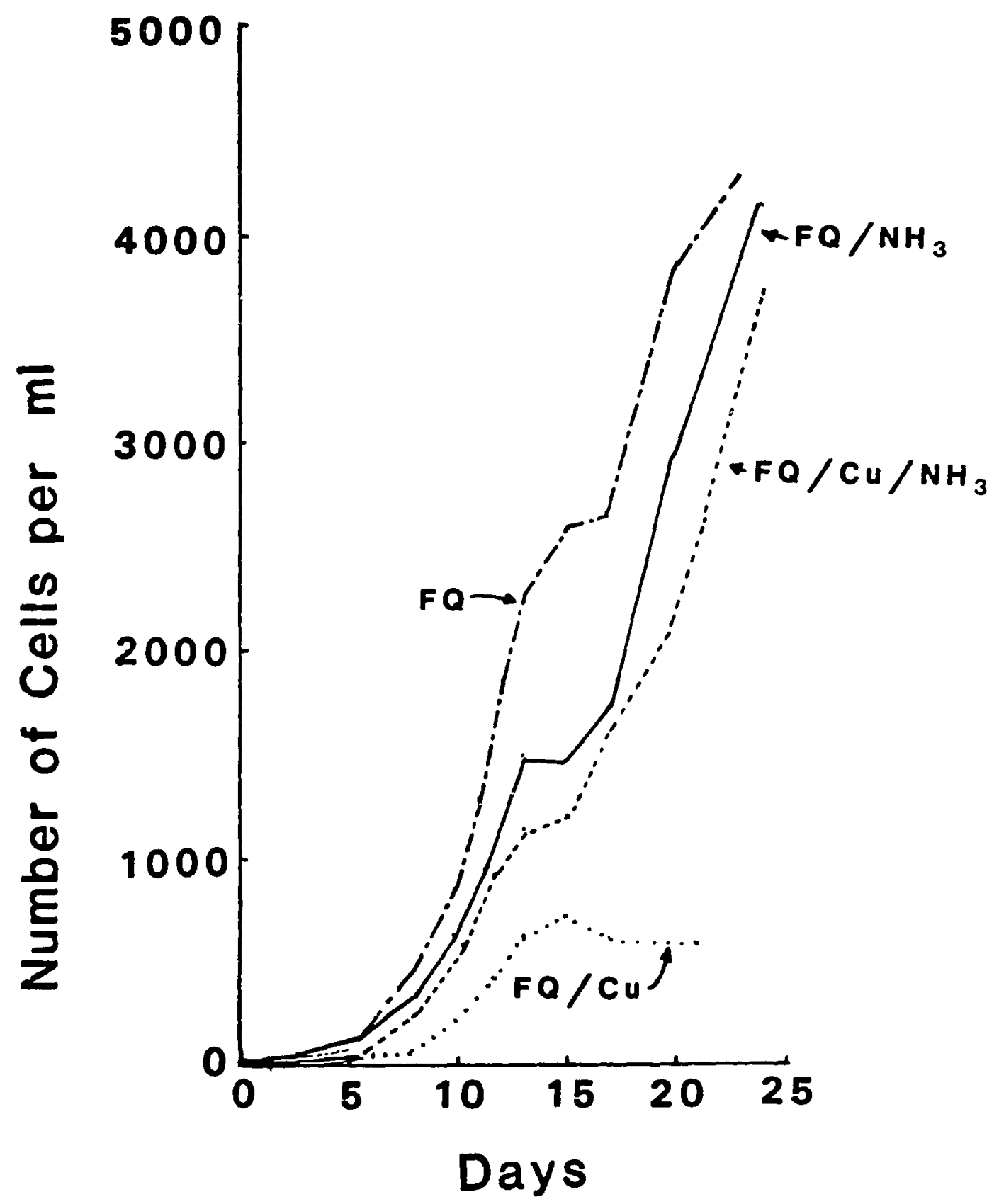

Figure 47. Cell number/ml vs. time with copper and different nitrogen sources. $F Q=$ FRAQUIL; $\mathrm{FQ} / \mathrm{CU}=$ FRAQUIL with copper $\left(1.3 \times 10^{-6} \mathrm{M}\right) ; \mathrm{FQ} / \mathrm{NH}_{3}=$ FRAQUIL with ammonia substituted for nitrate; $\mathrm{FQ} / \mathrm{Cu} / \mathrm{NH}_{3}=$ FRAQUIL with ammonia with copper $\left(1.3 \times 10^{-6} \mathrm{M}\right)$. 
nitrate reductase. Copper has been found to inhibit the activity of nitrate reductase and the uptake of nitrate and ammonium uptake (Harrison et al., 1977). Shioi et al. (1978b), from their work with Ankistrodesmus suggest that this may occur because copper inactivates the electron transport of photosystem II and there is not an adequate supply of reductants for nitrate reduction. This would help explain why copper has more of an effect on nitrate uptake than on the reduced form of nitrogen, ammonia. Previous work has also demonstrated that copper does decrease photosynthesis and chlorophyll content (McBrien and Hassall, 1965; Steemann Nielsen et al., 1969; Overnell, 1975; and Rosko and Rachlin, 1977). Nitrogen availability may be affected by the direct effect of copper as well as the indirect effects of photosynthesis in providing reductants. The form of nitrogen that is present becomes increasingly important to the cells when metals such as copper are in the environment to affect their availability.

\section{CONCLUSION}

The onset of sexual reproduction is linked to depletion of nitrate in the medium in one of the strains (\#96) tested. When copper delayed nitrate uptake, sexual reproduction was delayed; when copper stimulated nitrate uptake, sexual reproduction occurred earlier. Copper did not have this effect when ammonia was the nitrogen source. The key to sexual reproduction in closterium is not total nitrogen 
in the cell, but the supply outside the cell and this must be in the form of nitrate.

Copper generally inhibited nitrate uptake in long and short term experiments. The dosage response was demonstrated also by the stimulation of nitrate uptake (and cell division) at $\mathrm{pCu}$ * 14.4

The increase in cell number parallels nitrate depletion in batch cultures. Although cells must make contact before sexual reproduction can occur, cell number is not critical in the process. The trigger is metabolic, from the depletion of nitrate.

After sexual reproduction has occurred, the zygotes need maturation time in the dark. Upon being returned to light conditions and having nutrients added, germination occurs. The presence of added copper did not affect the percent germination. Abortion rate was not affected by copper.

The following chapter (Chapter V) shows morphological effects due to excess copper. 


\section{CHAPTER V}

\section{EXCESS COPPER AFFECTS CELL MORPHOLOGY}

\section{INTRODUCTION}

A commonly observed effect of heavy metal poisoning is changes in cell size and morphology (Thomas et al.. 1980). This phenomenon has been seen in Chlorophyceae (Rosko and Rachïin, 1977); Chrysophyceae (Davies, 1974); and Bacillariophyceae (Nuzzi, 1972; Sunda and Guillard, 1976; Berland et al., 1977; and Morel et al.. 1978). Morel et al. (1978) reported morphological aberrations in Skeletonema costatum at the same copper activities that began to increase the lag phase of growth in batch cultures. With Closterium, however, these aberrant forms, particularly the unseparated cells, can be found in nature and in untreated cultures. Ichimura and Watanabe (1976) reported morphological variation among three related species of Closterium. What is significant here is the increase in the number of aberrant cells.

The effect of copper on morphology is probably not a direct effect but is due to its effect on the growth and metabolism of the cell. The uncoupling of cell growth and cell division by the action of trace metals has been suggested by Davies (1976) as an explanation of the 
phenomenon of changes in morphology. When treated with trace metals, the cells may continue to grow but the normal separation does not occur. Favorable growth conditions may also cause this uncoupling as shown by playfair (1910) when cell division in Closterium was accelerated and occurred before new semi-cells were completely formed.

\section{RESULTS AND DISCUSSION}

Closterium moniliferum displaying typical morphology is shown with light microscopy (Figures 4 and 48 ) and with the scanning electron microscope (SEM) (Figures 49 and 50). Pickett-Heaps (1973) suggests the use of SEM in taxonomic studies of desmids. SEM was used here not so much for an increase in magnification as for observation of changes that might occur with copper treatment.

From the increased lag phase in growth of copper-treated cells, (See Chapter III) it is apparent that completion of cell division is inhibited by copper. The inability of the cells to complete cell division is confirmed with photomicrography (Figures 13, 14, 23-27) and with SEM (Figures 28-30). Irregularities and loss of symmetry of cells are evident in this stereo pair of photographs (Figures 51 and 52 ).

Gross distortions occur as cells continue to grow and deposit cell wall without dividing or expanding (Figures 29 and 30) or appear to repeatedly begin the division process (Figures 31,$32 ; 53$ and 54 ). 


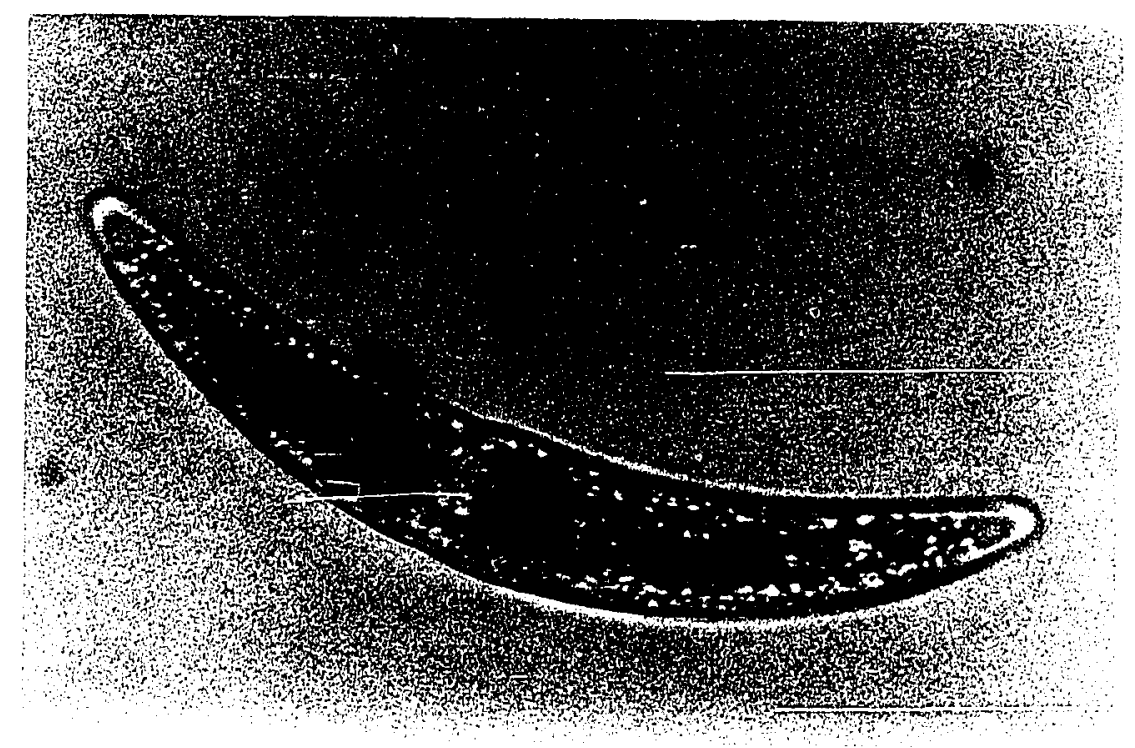

Figure 48. Typical morphology strain 96 of Closterium moniliferum. Cell with typical morphology with one semi-cell that has not yet attained maximum size for the cell to be considered mature. LM $430 \mathrm{X}$. 


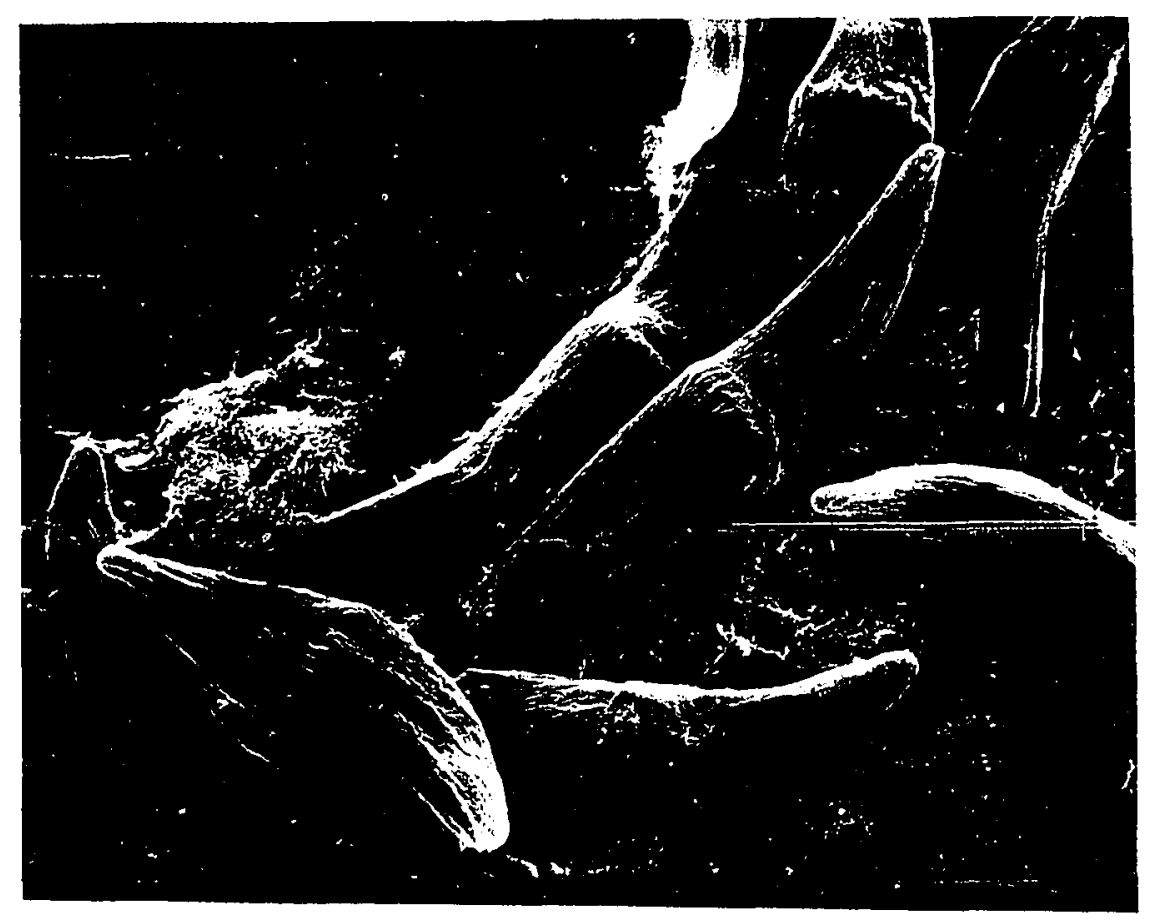

Figure 49. Mature symmetrical healthy cells of strain 96 of Closterium moniliferum. SEM $500 \mathrm{X}$. 


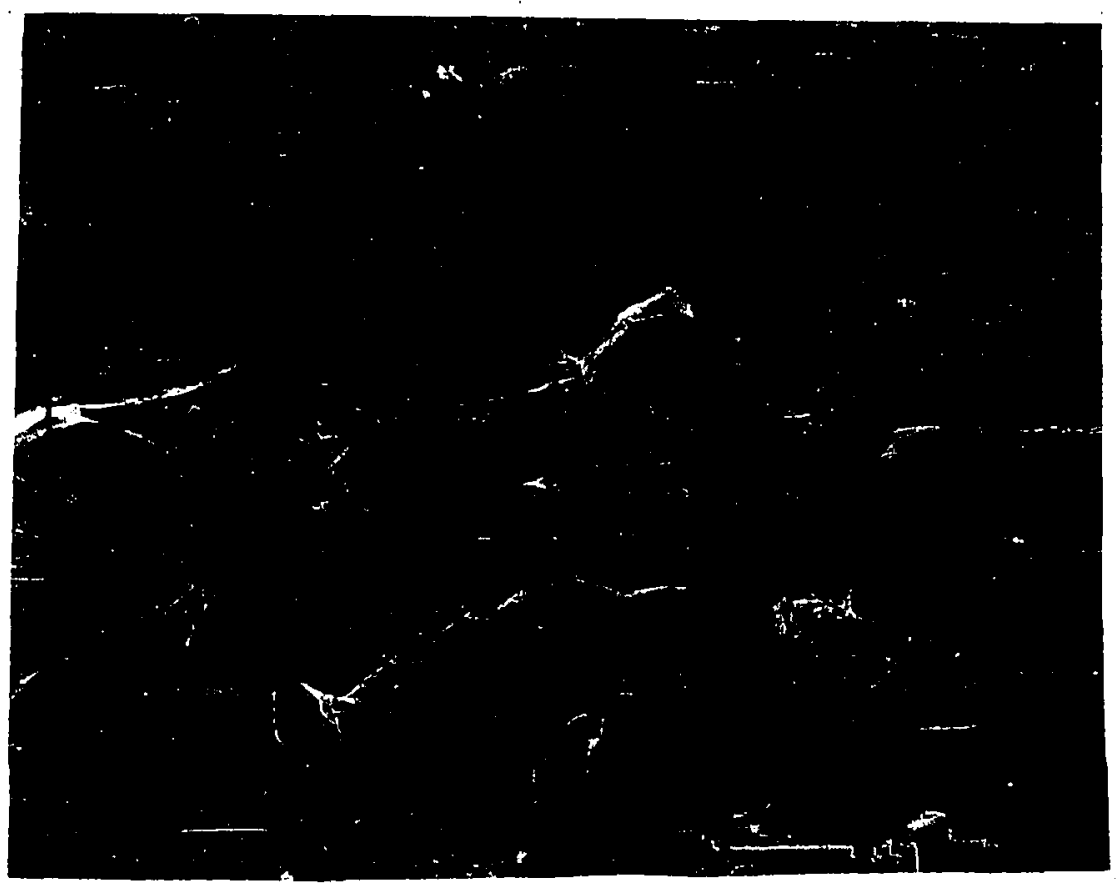

Figure 50. Dynamic focusing with the scanning electron microscope. Strain 96 of Closterium moniliferum. Mature symmetrical cells that have not been treated with copper. SEM $500 \mathrm{X}$. 


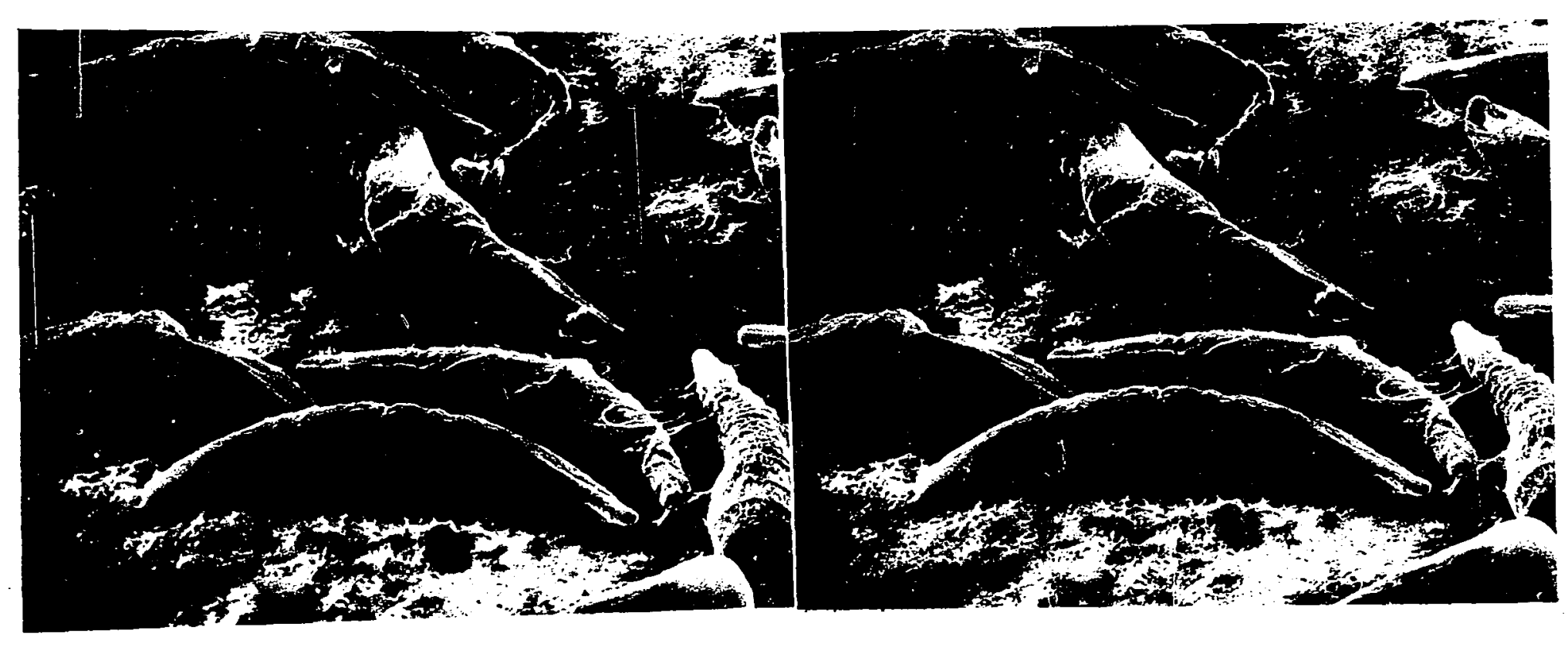

Figures 51 and 52. Stereo pair of electron micrographs of strain 96 of Closterium moniliferum treated with copper. Cells should be viewed through a stereo-viewer or by briefly staring cross-eyed at the two micrographs until the two images merge. SEM $500 \mathrm{x}$. 


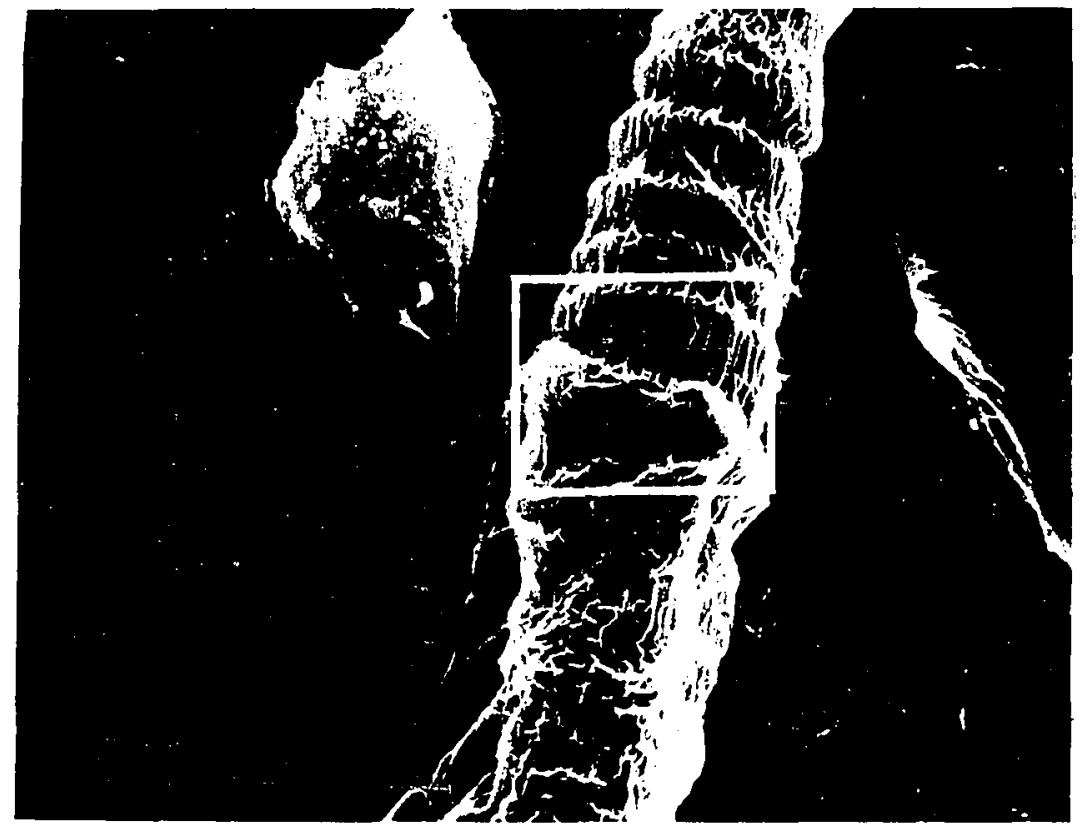

Figure 53. Copper treated cell of strain 96 of Closterium moniliferum. SEM $500 \mathrm{X}$.

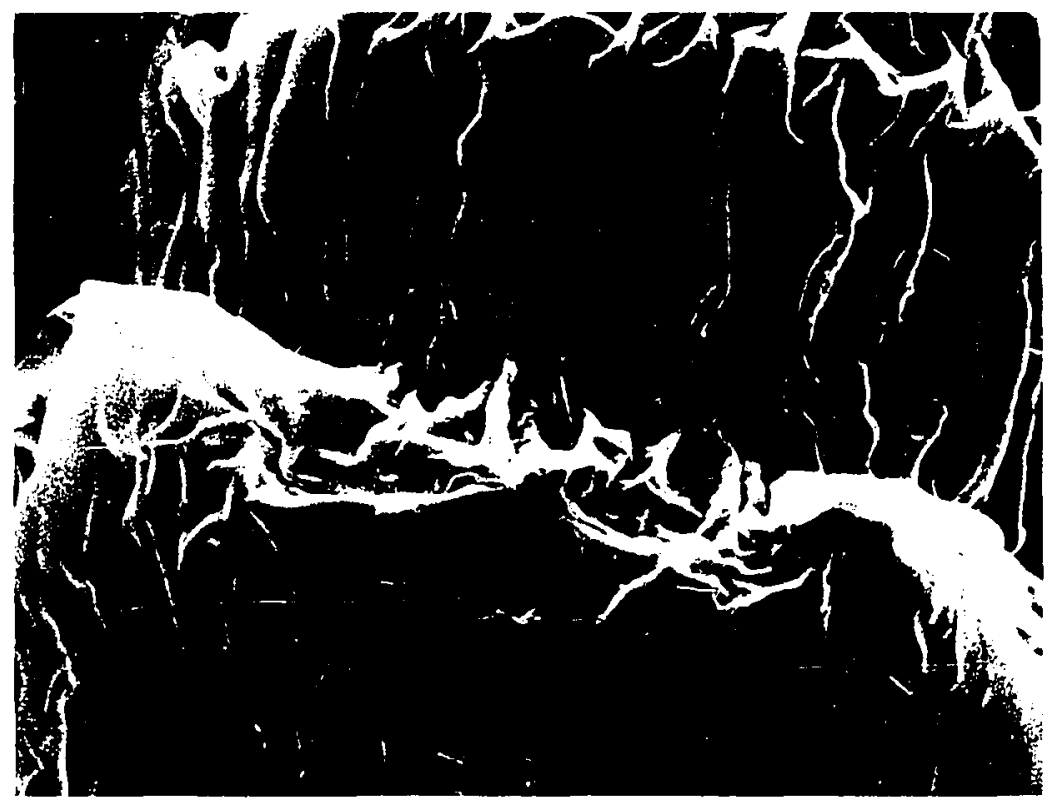

Figure 54. Enlargement of rectangle in Figure 53 . 
With added copper, the total amount of chlorophyll produced was decreased. When cells fail to divide, the amount of chlorophyll/cell may be higher (See Table IV) but shrunken protoplasts are visible with light microscopy (Figures 40-44) and with SEM, lack of vigor is indicated by the flaccid cell membrane (Figure 39).

Another morphological effect observed in vegetative cells was the formation of large vacuoles throughout the cell (Figures 43 and 44 ).

In long term growth experiments, an increase in number of aberrant cells did not begin to appear until day 6 or 7. Aberrant cells consist of those cells that did not complete separation (Figures 23-30), those with shrunken protoplasts (Figures 39-44) or vacuoles (Figures 43 and 44), and those of distorted morphology (Figures 31-34). In the first days of the experiment the highest percent of aberrant cells occurred in the cultures with $\mathrm{pCu} *=12.1$ $(T a b l e x)$. In cultures where sexual reproduction occurred earlier $\left(\mathrm{pCu}^{\star}=14.4\right)$ with strain \#96 the percent of aberrant cells increased greatly throughout the experiment witn a high in one experimental flask of $56.7 \%$ of the total cell number aberrant. However, this was probably not due to copper's immediate effect, but due to senescence and/or nutrient depletion since those cells took up nitrate (and presumably other nutrients) more quickly.

At $\mathrm{pCu}^{\star}=5.5$, cultures were not viable. In growing cultures, the number of cells counted as dead (Figures 55- 
TABLE X

PERCENT ABERRANT CELLS

$\begin{array}{ccc}\mathrm{pCu} & \text { Day } 7 & \begin{array}{c}\text { Average } \\ (3 \text { weeks })\end{array} \\ 15.4 & 0.95 \% & 5.98 \\ 14.4 & 1.5 \% & 10.98 \\ 13.4 & 3.7 \% & 9.3 \% \\ 12.1 & 11.2 \% & 14.38\end{array}$


57) when treated with sub-lethal concentrations of copper was not significantly different from that of cultures without added copper. In other words, although growth (cell number increase) was inhibited at sub-lethal concentrations of copper, it was due to less cell division, not death of individual cells.

It is known that Closterium species produce mucilage; in fact, that is the mechanism for movement in this organism. Quantitative differences in mucilage production due to copper were not measured nor were differences obvious with SEM (Figures 58 and 59).

The two strains of Closterium moniliferum studied differed in their sexual reproduction in that \#171 produces twin zygotes (Figures 10 and 60-68), whereas \#96 produces single zygotes (Figures 69-72). In 1963, Cook proposed that sexual morphology be an essential feature in identification within closterium species so it is important to continue to monitor both sexual and asexual phases for morphological changes due to copper.

When the sexual process did not go to completion, the zygotes aborted (Figures 73-76). The difference in the number of abortions in populations treated with copper and those without was not significant. This indicates that although copper affects sexual reproduction by delaying its onset, once the process begins copper is not a factor in affecting it. 

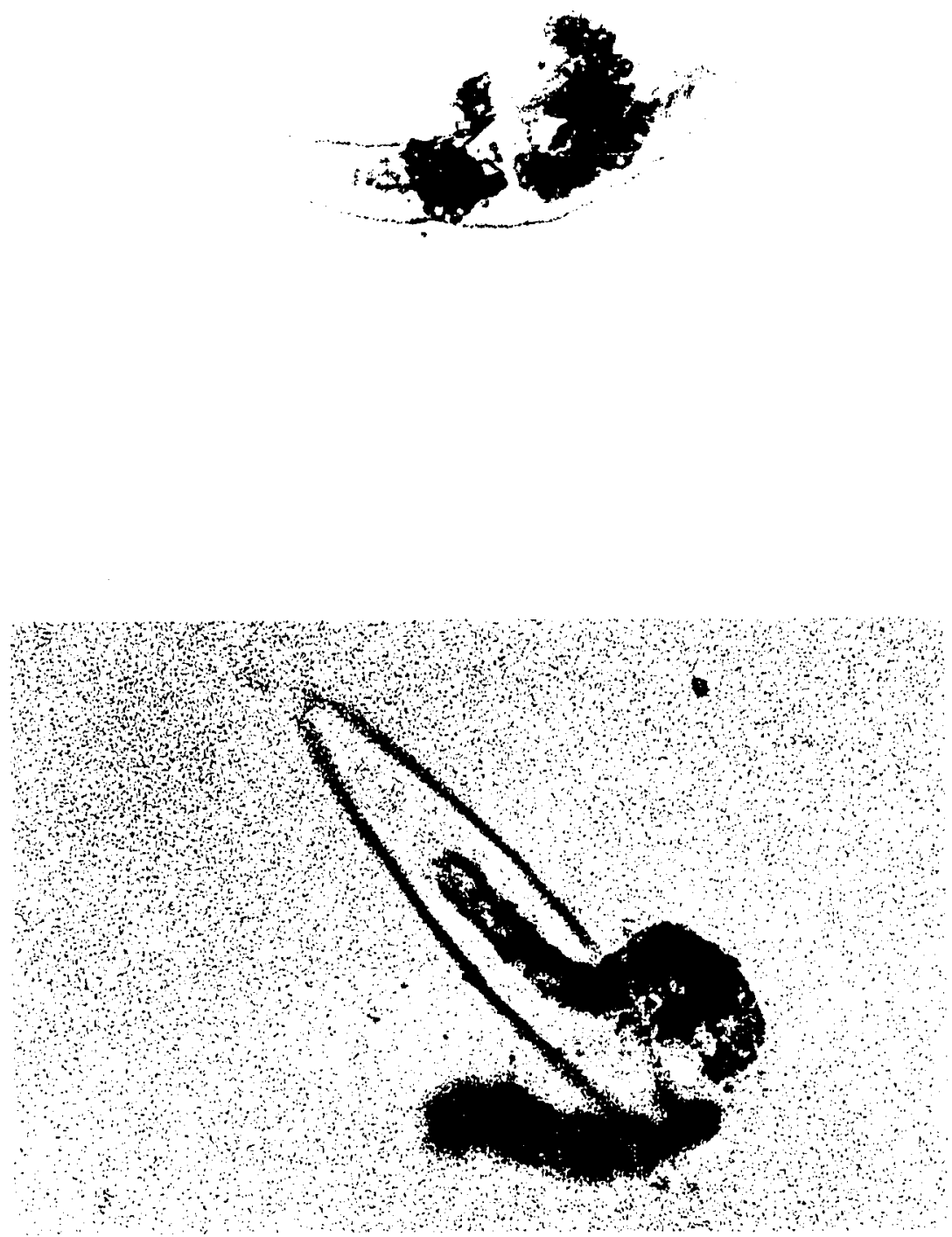

Figures 55 and 56. Lysed non-viable cells of Closterium moniliferum. LM $430 \mathrm{X}$. 


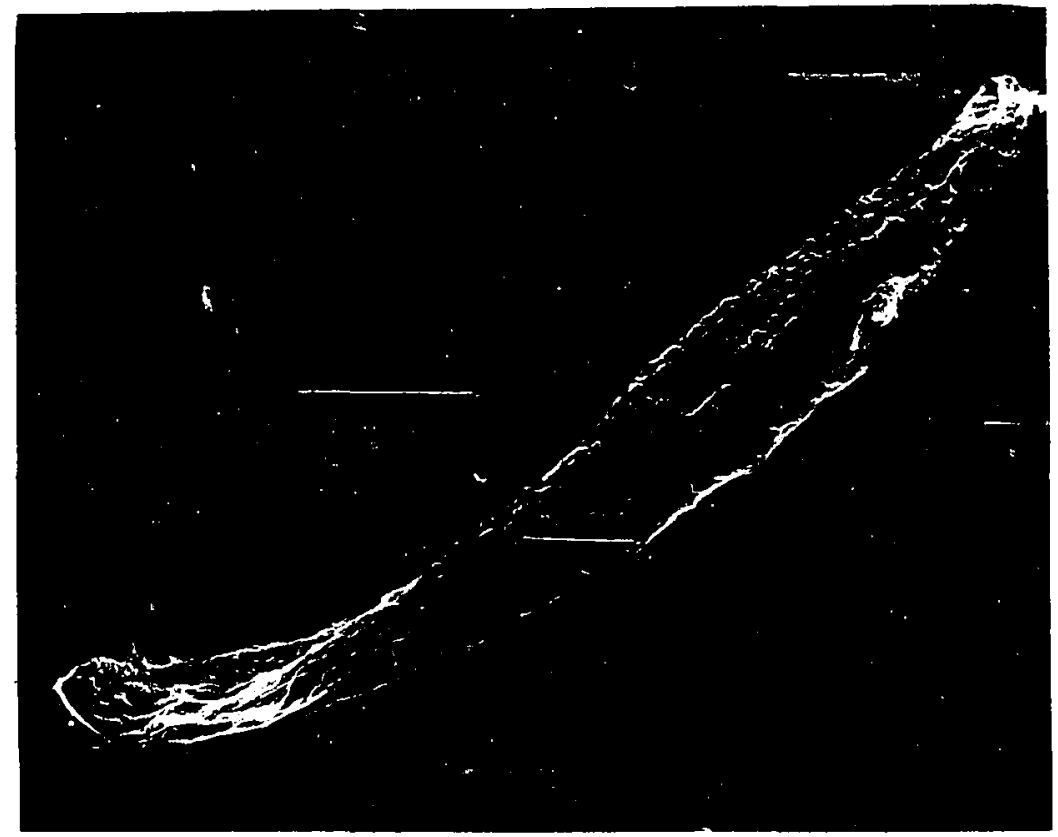

Figure 57. Abnormal cell of strain 96 of Closterium moniliferum. Appearance of a cell in a culture treated with excess copper. SEM $500 \mathrm{x}$. 


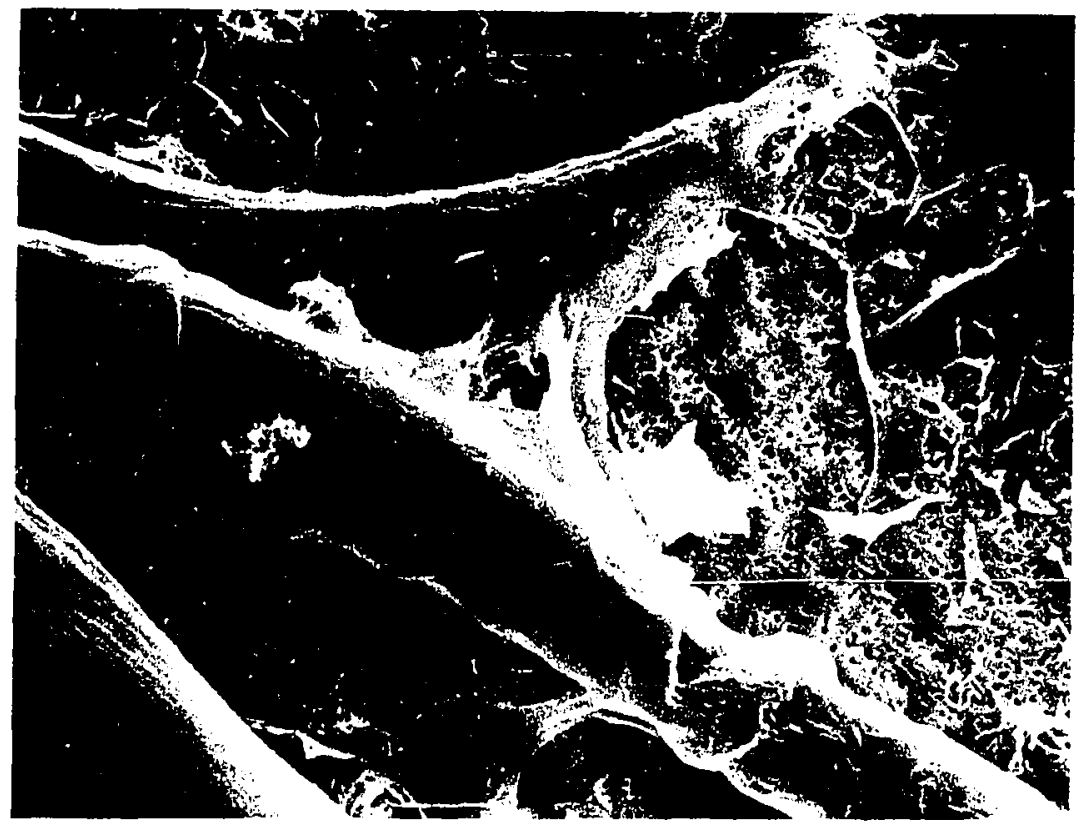

Figure 58. Mucilage in strain 96 of Closterium moniliferum. Note the mucilage between two cells. $\mathrm{pCu}^{\star}=15.4$ SEM $1000 \mathrm{x}$.

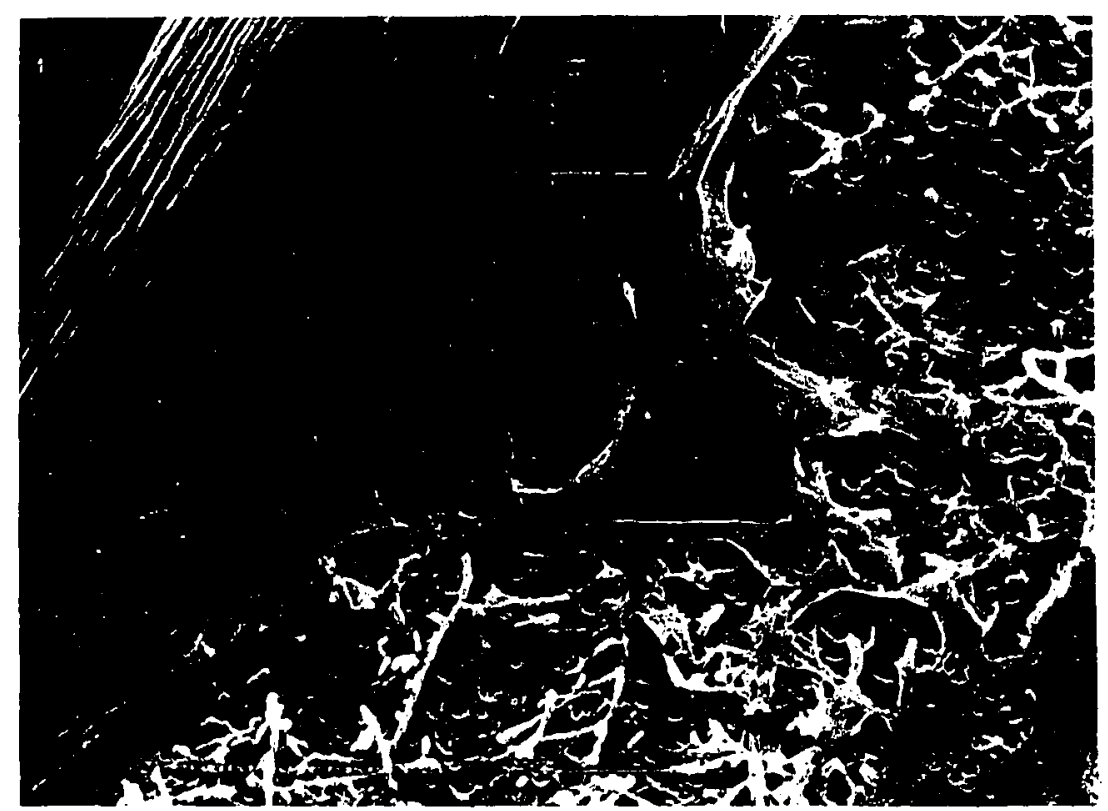

Figure 59. Mucilage in strain 96 of Closterium moniliferum. Mucilage when cells were grown at PCu ${ }^{\star}=12.1$. SEM $2000 \mathrm{X}$. 


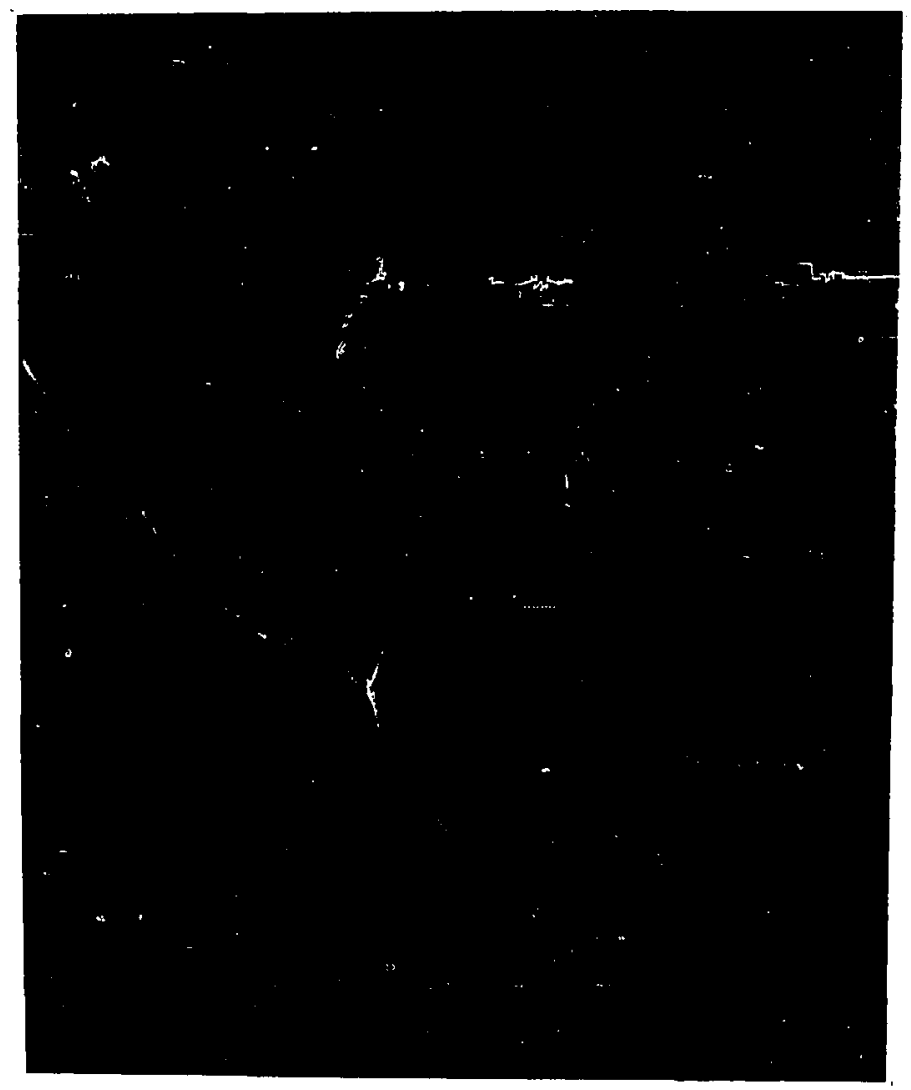

Figure 60. Papillae in strain 171 of Closterium moniliferum. This is the beginning of sexual reproduction. SEM $500 \mathrm{X}$. 

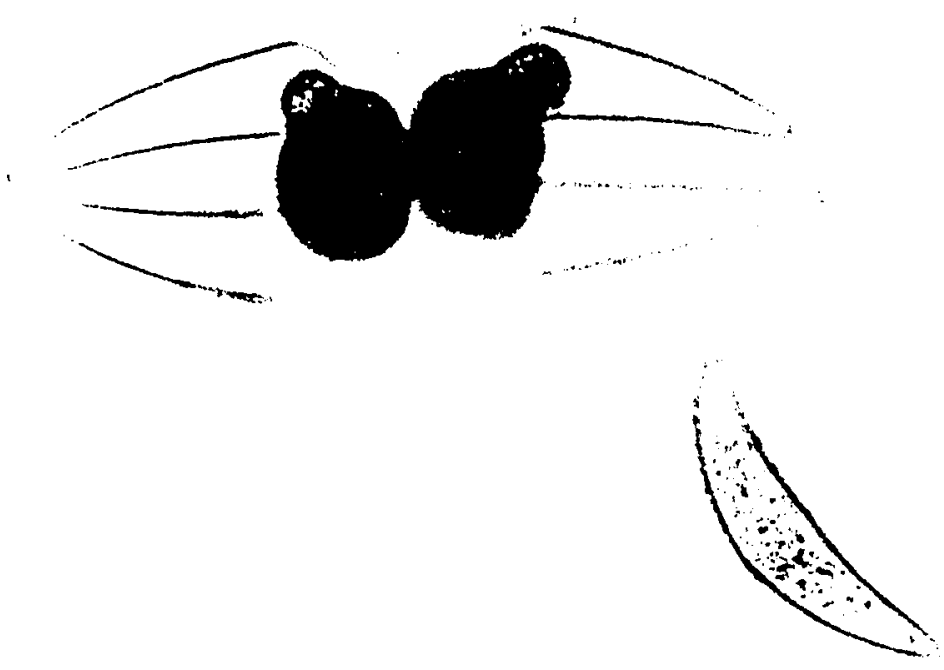

Figure 61. Strain 171 of Closterium moniliferum. Twin zygotes forming. LM $430 \mathrm{X}$.
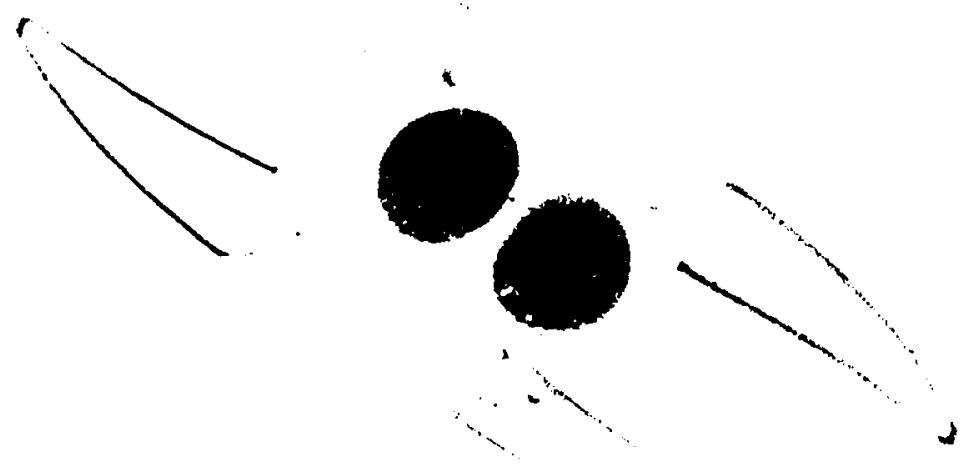

Figure 62. Twin zygotes of strain 171 of Closterium moniliferum with 4 empty cells. LM $430 \mathrm{X}$. 

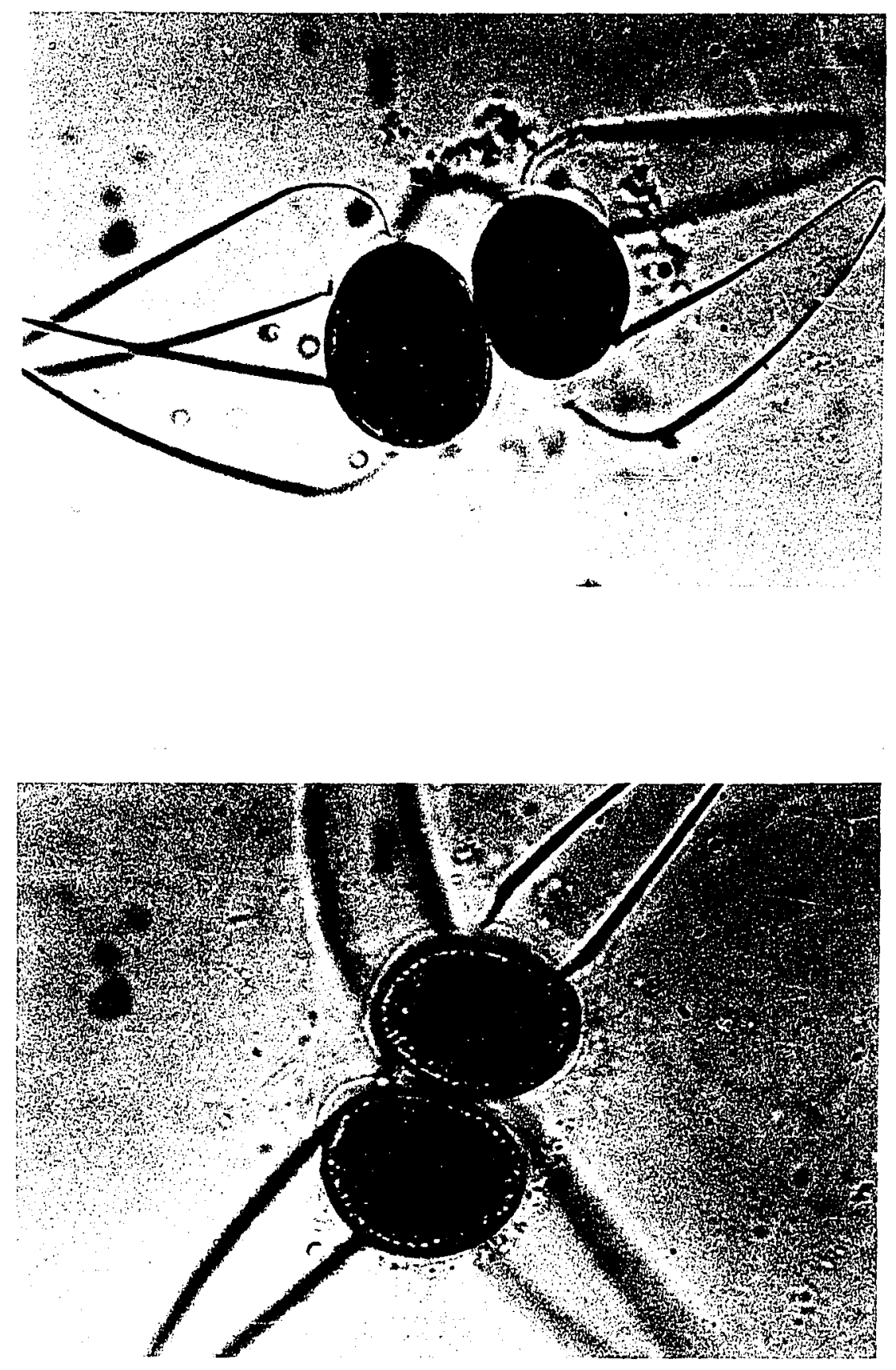

Figures 63 and 64 . Twin zygotes of strain 171 of Closterium moniliferum. LM $600 \mathrm{X}$. 


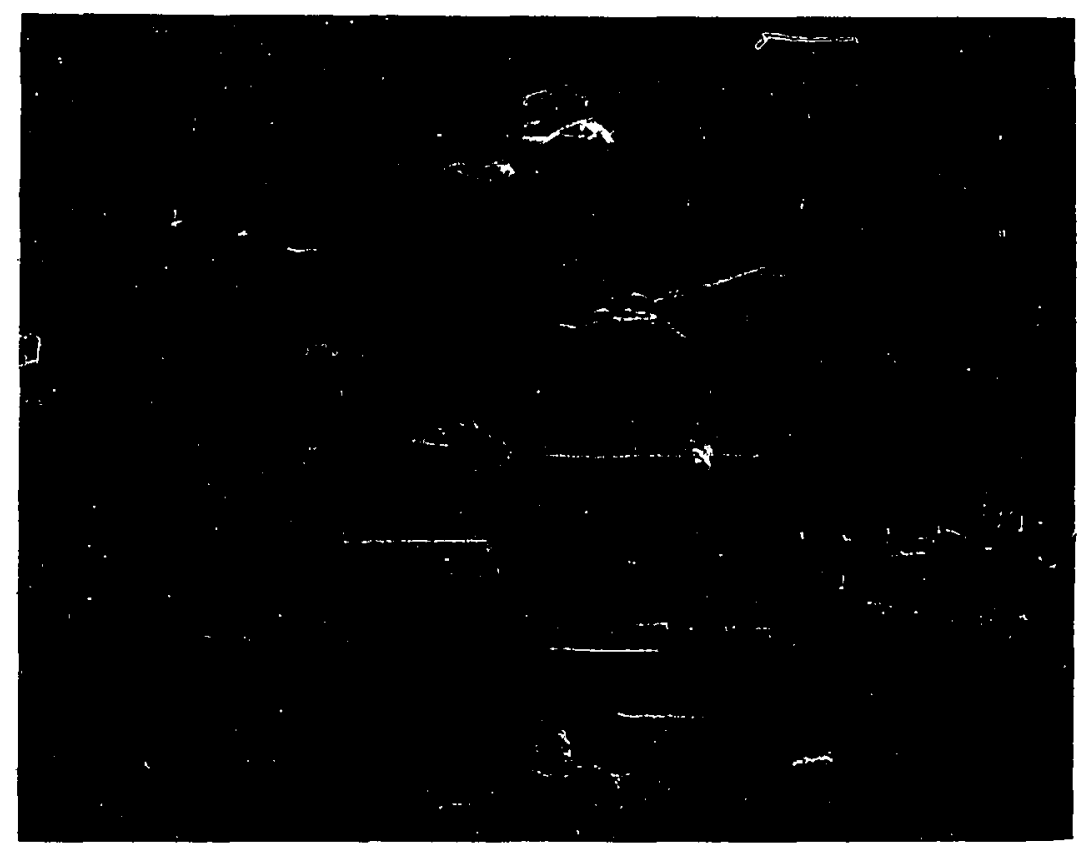

Figure 65. Zygotes of strain 171 of Closterium moniliferum. Twin zygotes in culture that had been treated with added copper. SEM $500 \mathrm{X}$.

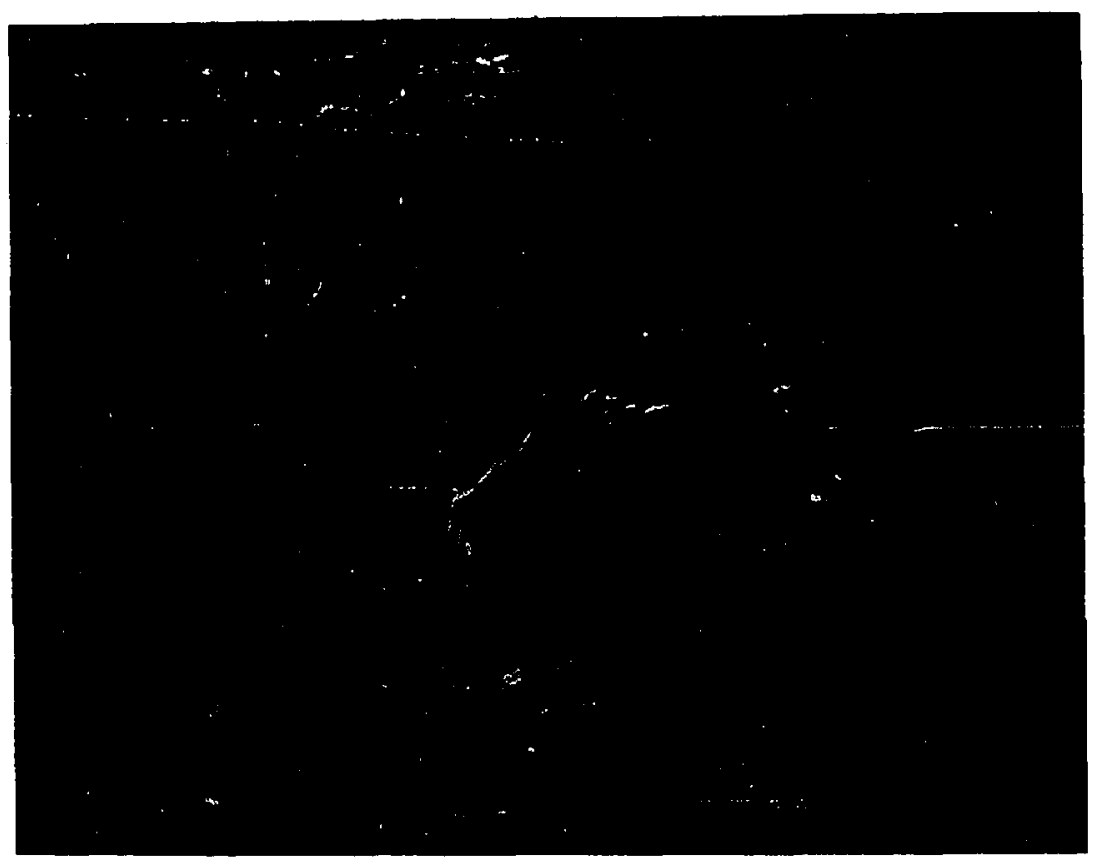

Figure 66. Zygotes of strain 171 of Closterium moniliferum. Twin zygotes in culture that had beer treated with added copper. SEM $1000 \mathrm{X}$. 


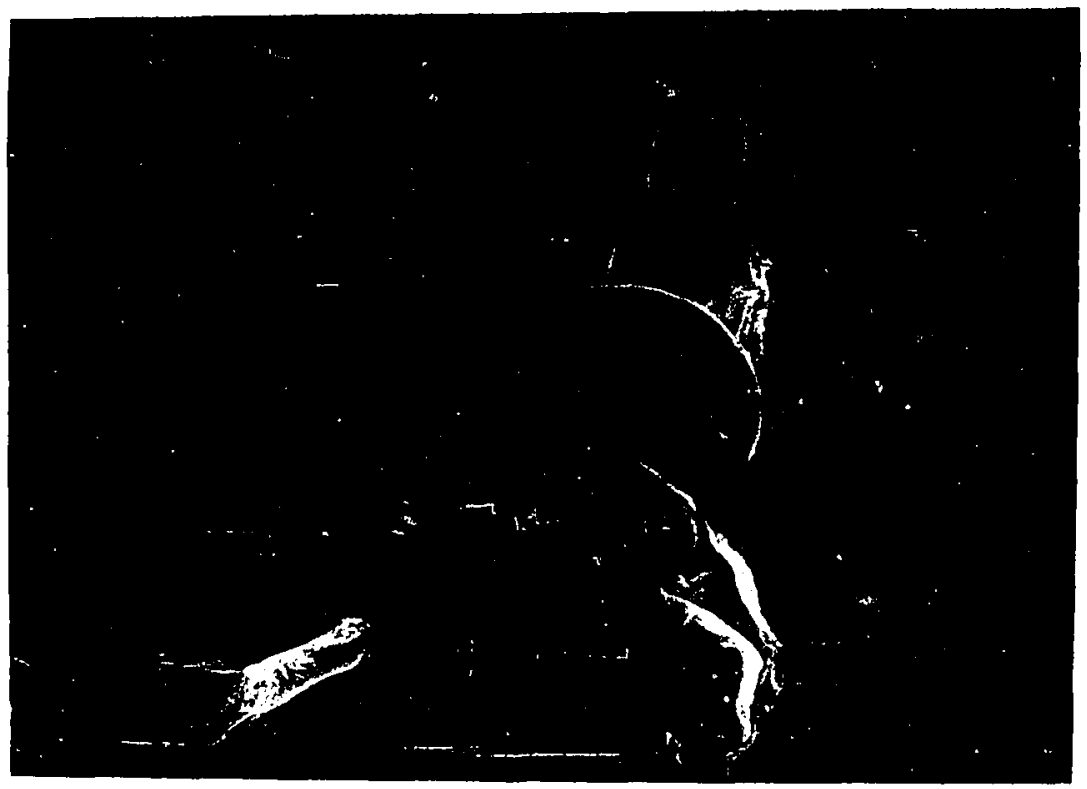

Figure 67. Twin zygotes of strain 171 of Closterium moniliferum. Empty cells remain after sexual reproduction. SEM $500 \mathrm{X}$.

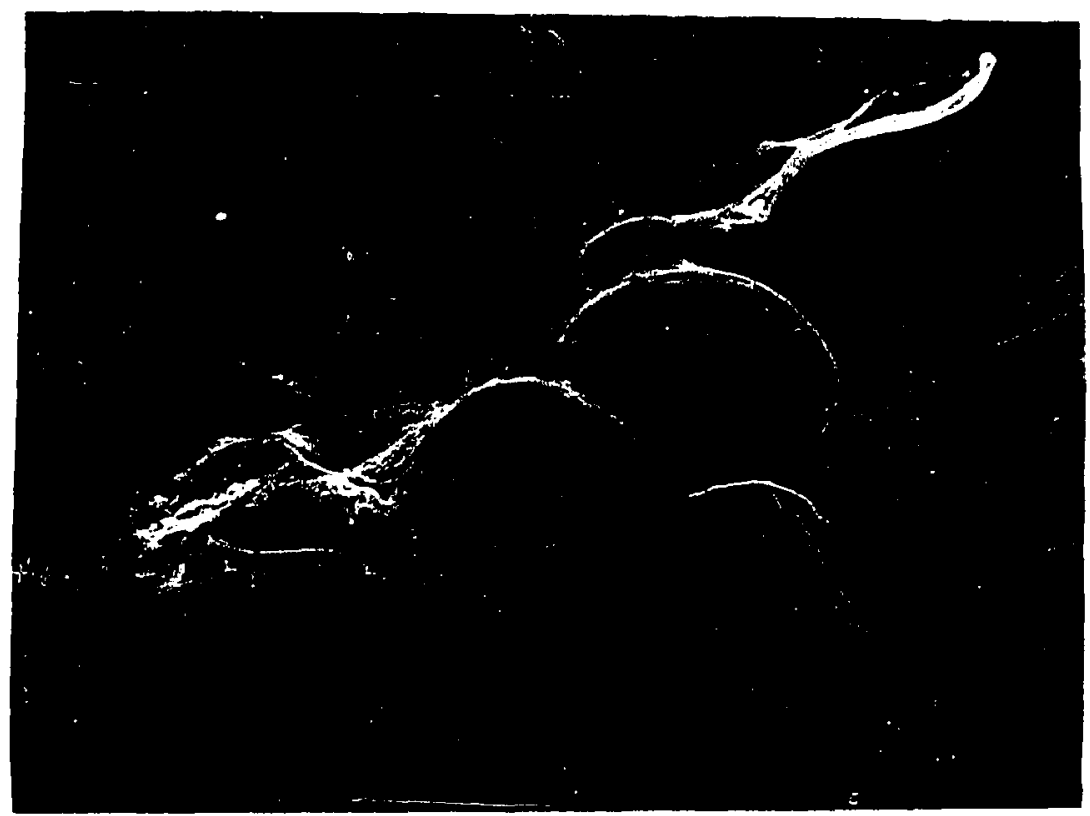

Figure 68. Twin zygotes of strain 171 of Closterium moniliferum. Empty cells remain after sexual reproduction. SEM $500 \mathrm{X}$. 


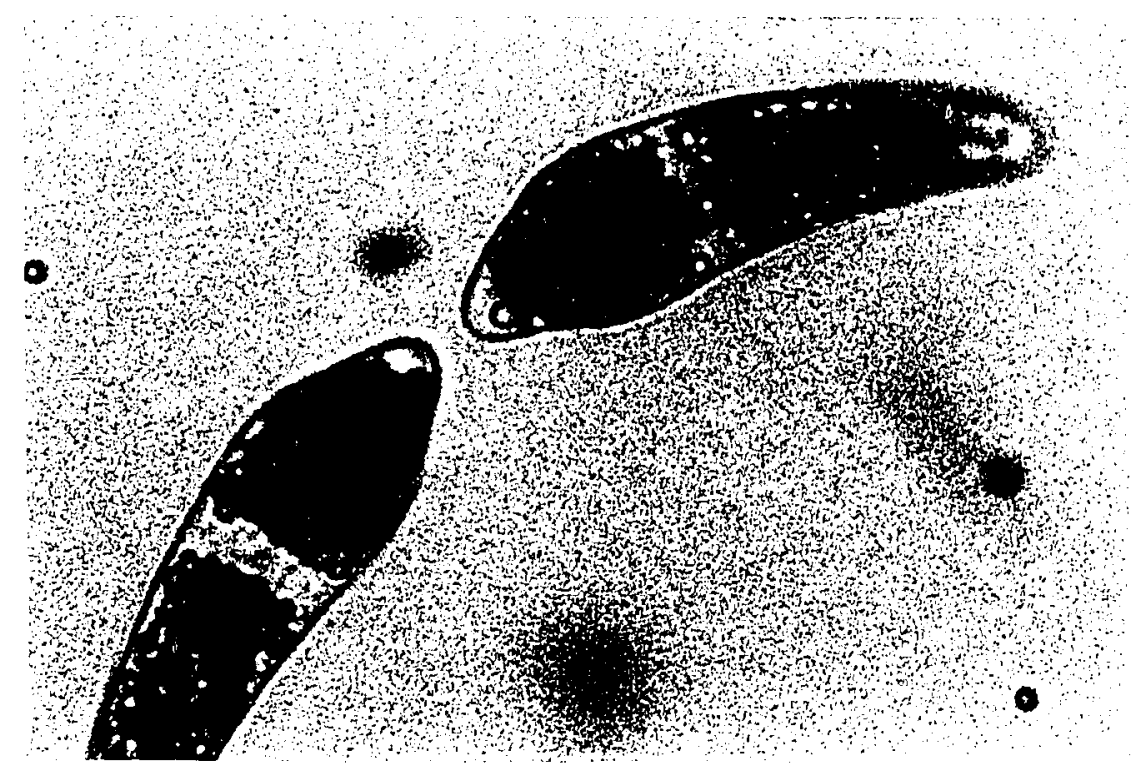

Figure 69. Two immature cells of strain 96 of Closterium moniliferum pairing before conjugation.

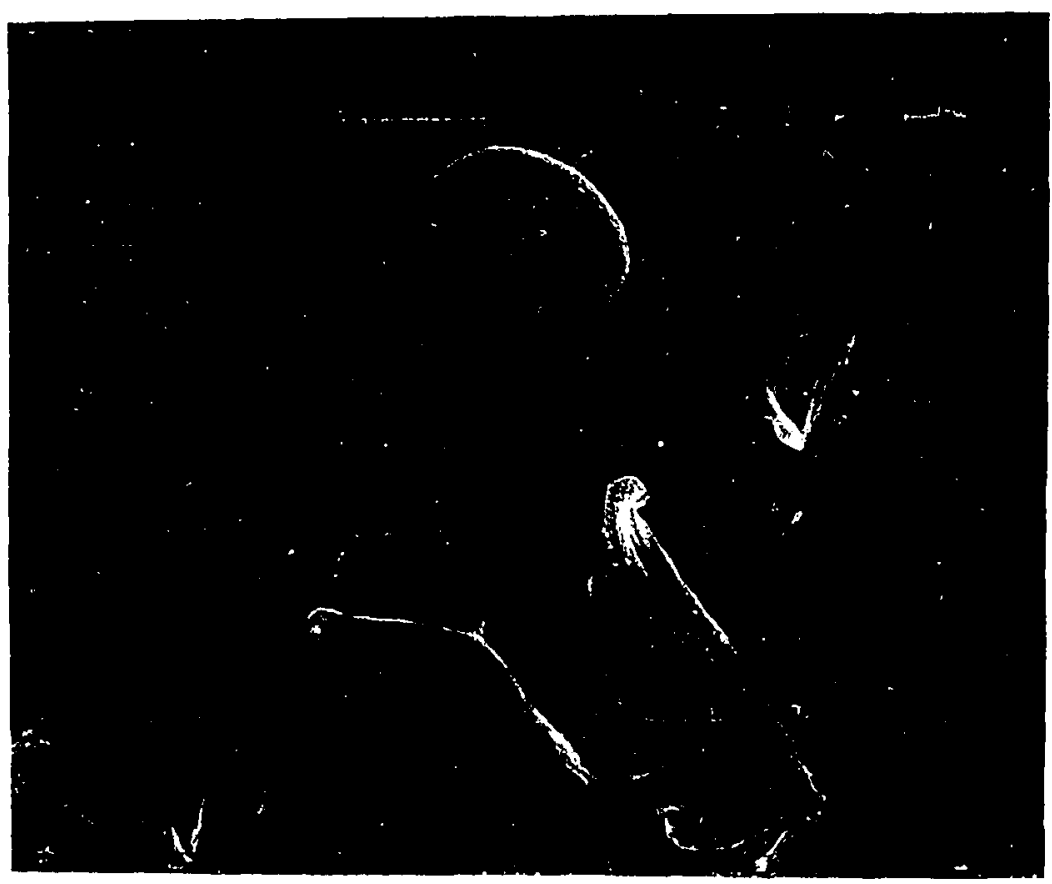

Figure 70. Scanning electron micrograph of zygote of strain 96 of Closterium moniliferum. Empty cells are nearby. SEM $500 \mathrm{X}$. 


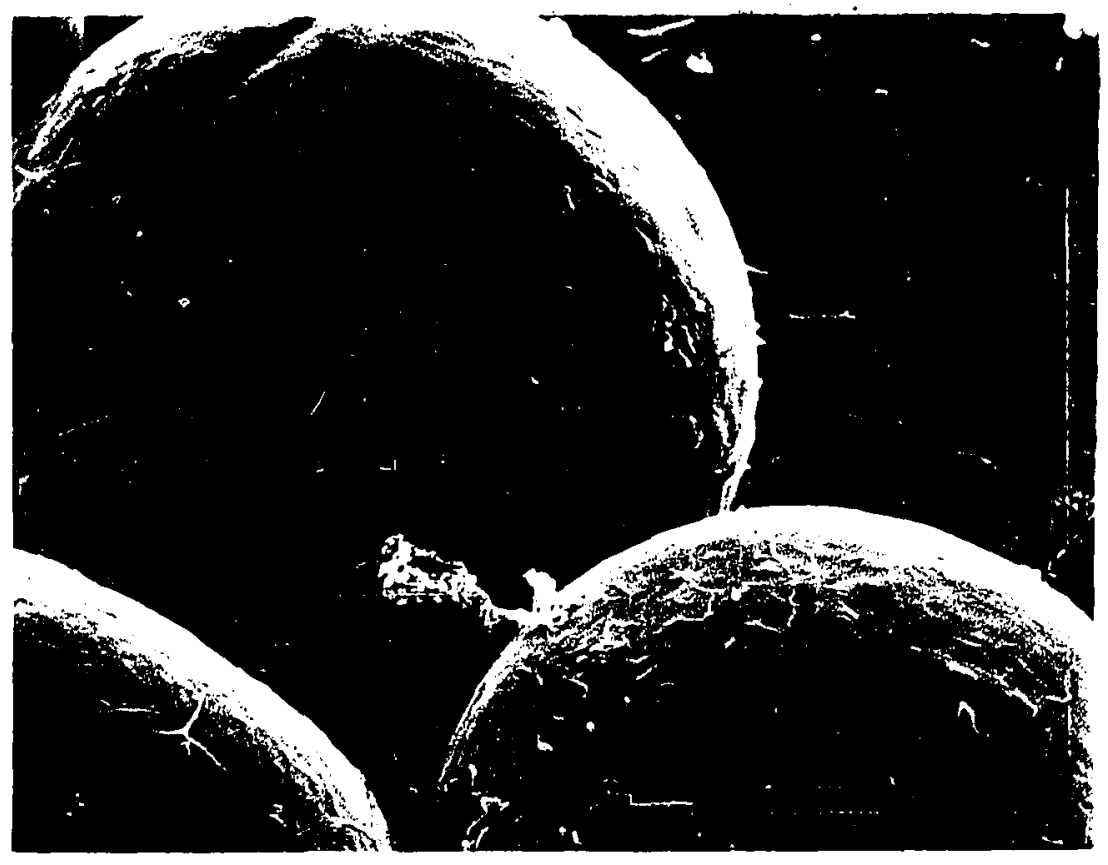

Figure 71. Zygotes of strain 96 of Closterium moniliferum that are still covered with the mucilagenous sheath from the conjugation vesicle. SEM $2000 \mathrm{X}$.

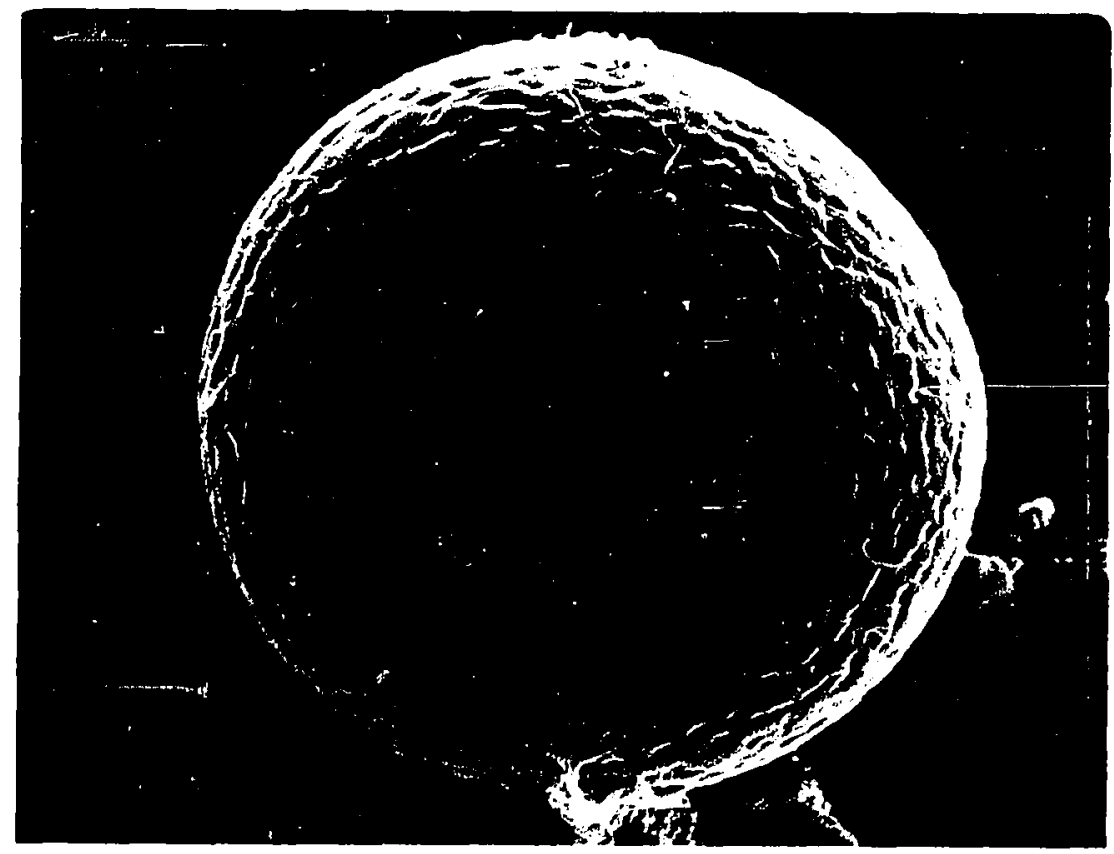

Figure 72. Zygote of strain 96 of Closterium moniliferum without mucilagenous material. SEM $2000 \mathrm{X}$. 

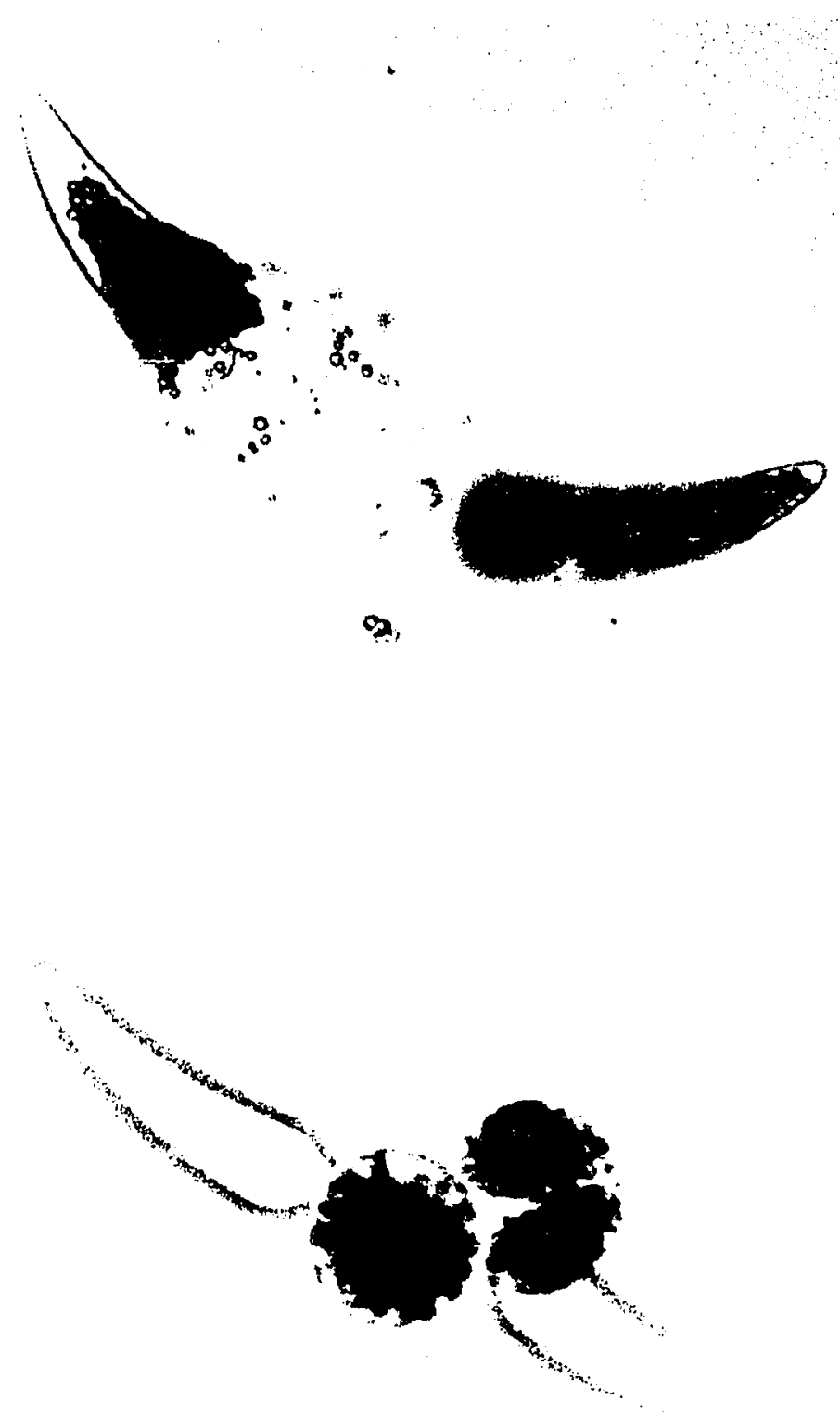

Figures 73 and 74. Abortion in strain 96 of Closterium moniliferum. Cell contents are being released before the conjugation vesicle formed (Top); Non-simultaneous release of cell contents (Bottom). LM $430 \mathrm{X}$. 


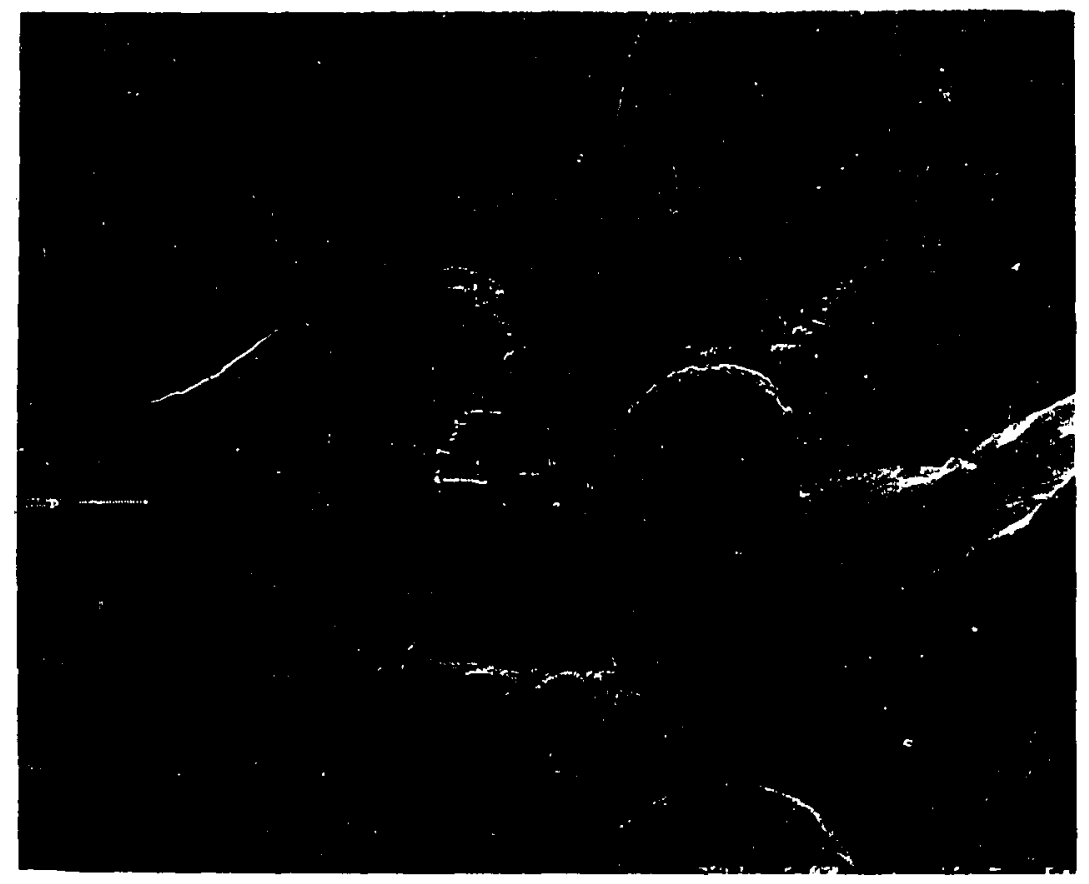

Figure 75. Abortion in strain 96 of Closterium moniliferum. On the right is a zygote formed; on the left and at the bottom of the micrograph are two abortions. SEM $500 \mathrm{X}$.

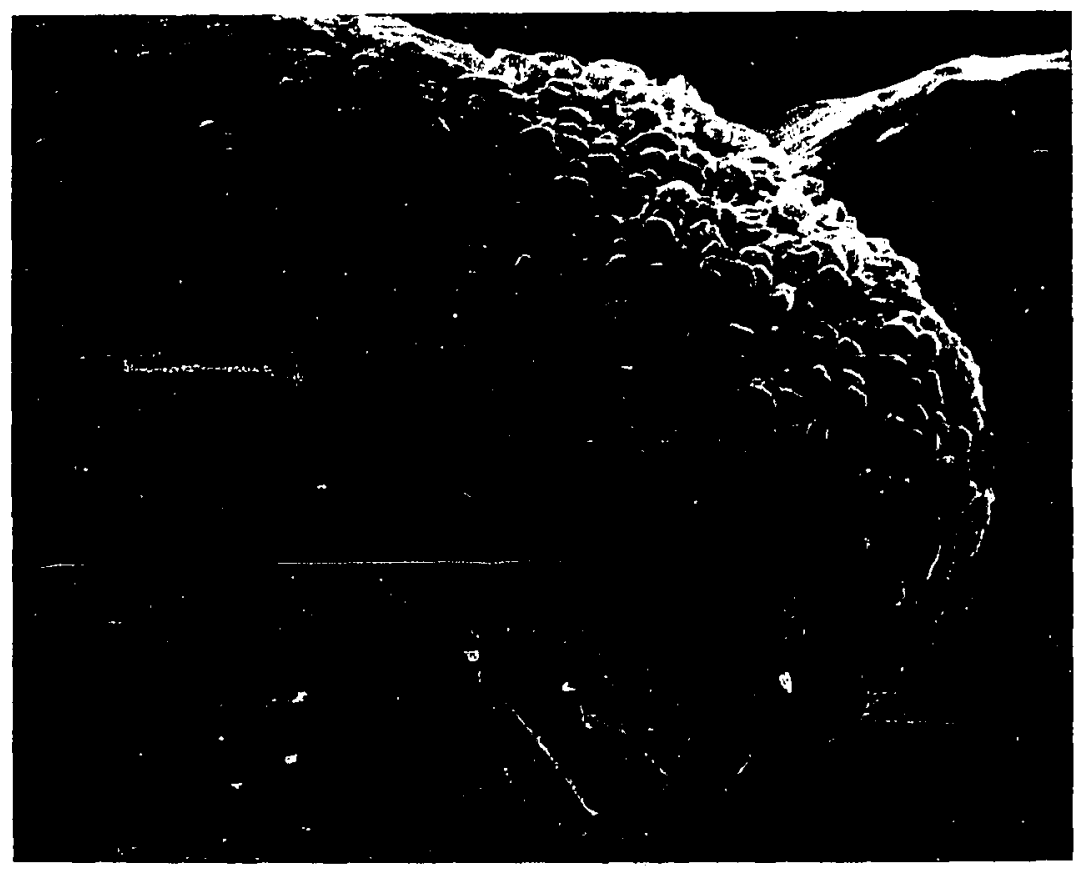

Figure 76. Enlargement of cell in upper left of figure 75. SEM $2000 \mathrm{x}$. 


\section{CONCLUSION}

The typical symmetrical cell shape of Closterium is affected by additions of copper. After cell division, the cell gorws and re-establishes the symmetry lost when it divided. When copper disrupts this growth process or the deposition of cell wall, distorted cells may result. Copper affects cell morphology by acting on the cell division (mitosis or cytokinesis) itself. Although growth was occurring, it is uncoupled from cell division and mature cells remained unseparated from each other. The unseparated cells, not being able to finish cell division, will not be involved in sexual reproduction since vegetative cell division is a prerequisite. It is improbable that the distorted cells could initiate or complete a normal conjugation. Thus, the main significance of copper's effect on morphology in regard to this work is the fact that frequency of sexual reproduction will be reduced due to lack of cell division. 
CHAPTER VI

CONCLUSION

This study examined the total life cycle of an organism and its response to copper. The growth of Closterium moniliferum with copper exemplifies the typical beneficial, inhibitory, and toxic dose-response to trace metals suggested in Chapter I. The stimulatory effect was demonstrated by an early increase in cell number, increased nitrate uptake, and early onset of sexual reproduction. The inhibitory effect, with greater concentrations of copper, was demonstrated by a longer lag phase, decreased nitrate uptake, and later onset of sexual reproduction. Since these cells are adaptable with time, one of the final effects of sublethal concentrations of copper within the medium was to affect the timing of the life cycle.

The sexual phase in some strains of closterium moniliferum can be triggered by nitrate depletion in the media. Although it was expected that each cell would have a minimal cell quota of nitrogen before sexual reproduction occurred, work with strain 96 demonstrated that $Q$ (nitrogen/ cell) was not the critical factor in initiation of the process. It was also demonstrated the cell number in batch cultures was not the critical factor. When ammonia was the only nitrogen source and it became depleted in the 
medium, sexual reproduction did not occur. Nitrate depletion appears to be the critical component in induction of sexual reproduction.

When copper was added to batch cultures with different nitrogen sources, cells growing with nitrate were inhibited more than cells growing with ammonia. This information gives direction to further research in using copper as a tool in understanding nitrogen metabolism in microorganisms, particularly in desmids where sexual reproduction is integrally tied to the nitrogen requirements of the cell. Figure 46 shows possible sites of action of copper on nitrogen metabolism. Further work should include an examination of any of these sites that may be blocked. For example, the action of copper on nitrate uptake could be directly on the enzyme nitrate reductase. Since nitrate reductase is an inducible enzyme, antibiotics inhibiting protein synthesis could be used in combination with copper to help understand whether copper affects synthesis or activity of nitrate reductase.

The rate of germination of zygotes was not correlated with $\mathrm{pCu}^{*}$. After germination, however, the vegetative cells would again be susceptible to copper's effect. Abortion rate was not correlated with $\mathrm{pCu}^{*}$. It appears that the effect of copper occurs early in cell growth or on induction of sexual reproduction. Once the process of sexual reproduction is allowed to begin, copper's effect is not evident. 
In natural waters, conjugation in desmids is most frequent in very shallow waters which can absorb carbon dioxide from the atmosphere or possibly from respiration from bottom muds (Brook, 1981). Such conditions prevail in bogs and temporary pools with changing water levels and where, clearly, the production of resistant zygospores would have considerable survival value. Similarly, the stimulatory effect of copper with its accompanying earlier sexual reproduction could have survival value for Closterium moniliferum. 
LITERATURE CITED

Anderson, D.M. and F.M.M. Morel. 1978. Copper sensitivity of Gonyaulax tamarensis. Limnol. Oceanogr. $\underline{23}: 283-295$.

Aparicio, P.J., J. Cardenas, W.G. Zimft, J. Ma Vega, J. Herrera, A. Paneque, and M. Losada. 1971. Molybdenum and iron as constituents of the enzymes of the nitrate reducing system from Chlorella. Phytochemistry $10(7): 1487-1495$.

Barber, R.T. and J.H. Ryther. 1969. Organic chelators: Factors affecting primary production in the Cromwell Current upwelling. J. exp. Mar. Biol. Ecol., $\underline{3}$ : 191-199.

Bentley-Mowat, J.A. and S.M. Reid. 1977. Survival of marine phytoplankton in high concentrations of heavy metals, and uptake of copper. J. exp. Mar. Biol. Ecol. 26:249-264.

Berland, B.R., D.J. Bonin, O.J. Guérin-Ancey, V.I. Kapkov, and D.P. Arlhac. 1977. Action de metaux lourds à des doses sublétales sur les charactéristiques de la croissance chez la diatomée Skeletonema costatum. Mar. Biol. $\underline{42}: 17-30$.

Biebel, Paul. 1964. The sexual cycle of Netrium digitus. Am. J. of Botany 51:697-704.

Bienfang, P.K. 1975. Steady state analysis of nitrateammonium assimilation by phytoplankton. Limnol. Oceanogr. 20:402-411.

Bowen, Robert and Ananda Gunatilaka. 1977. Copper: Its Geology and Economics. A Halsted Press Book. John Wiley \& Sons. N.Y. page 9.

Braek, Gudmund Skjak, Arne Jensen, and A. Mohus. 1976. Heavy metal tolerance of marine phytoplankton. III. Combined effects of copper and $z$ inc ions on cultures of 4 common species. J. exp. Mar. Biol. Ecol. 25: 37-50.

Brook, Alan J. 1981. The Biology of Desmids. Blackwell Scientific Publications, Oxford. 276 pages. 
Cain, J. 1965. Nitrogen utilization in 38 fresh water chlamymonad algae. Can. J. Bot. 43:1367-1378.

Caperon, John and Judith Meyer. 1972a. Nitrogen-limited growth of marine phytoplankton I. Changes in population characteristics with steady-state growth. DeepSea Res. 19:601-618.

Caperon, John and Judith Meyer. 1972b. Nitrogen-limited growth of marine phytoplankton II. Uptake kinetics and their role in nutrient-limited growth of phytoplankton. Deep-Sea Res. 19:619-632.

Cedeno-Maldonado, Arturo, J.A. Swader and R.L. Heath. 1972. The cupric ion as an inhibitor of photosynthetic electron transport in isolated chloroplasts.

Plant Physiol. 50:698-701.

Coesel, P.F.M. 1974. The relevance of desmids in the biological typology and evaluation of fresh water. Hydrobiol. Bull. (Amsterdam) 9:93-101.

Darling, Michael Edwin. 1979. Copper toxicity and extracellular release in Selenastrum capricornutum. Ph.D. Thesis. Portland state University. l13 pages.

Davies, A.G. 1974. The gruwth kinetics of Isochrysis galbana in cultures containing sublethal concentrations of mercuric chloride. J. Mar. Biol. Ass. U.K. 54: $157-169$.

Davies, A.G. 1976. An assessment of the basis of mercury tolerance in Dunaliella tertiolecta. J. Mar. Biol. Assoc. U.K. 56:39-57.

Davis, Curtiss 0., James T. Hollibaugh, Don L.R. Siebert, William H. Thomas, and Paul J. Harrison. Formation of resting spores by Leptocylindrus damicus (Bacillariophyceae) in a controlled experimental ecosystem. J. Phycol. 16:296-302.

de Filippis, L.F. 1979. The effect of heavy metal compounds on the permeability of Chlorella cells. $\mathrm{Z}$. Pflanzenphysiol. $92: 39-50$.

Dubois-Tylski, T. and L. Lacoste. 1970. Action de la temperature et de l'eclairement sur la reproduction sexual d'un Closterium du group moniliferum. C.R. acad. sci. Paris. 270:302-305. 
Dustin, Pierre. 1947. Some new aspects of mitotic poisoning. Nature $159: 794-797$.

Eppley, Richard W. 1978. Nitrate uptake in Hellebust, J.A. and J.S. Craigie (Eds.) Handbook of Phycological Methods. Cambridge University Press. New York. pp. 401-409.

Eppley, Richard W. and Edward H. Renger. 1974. Nitrogen assimilation of an oceanic diatom in nitrogen-

limited continuous culture. J. Phycol. 10:15-23.

Eppley, Richard W. and Jane N. Rogers. 1970. Inorganic nitrogen assimilation of Ditylum brightwellii, a marine plankton diatom. J. Phycol. $6: 344-351$.

Eppley, Richard W., J.N. Rogers, and J.J. McCarthy. 1969. Haif saturation "constants" for uptake of nitrate and ammonium by marine phytoplankton. Limnol. Oceanogr. 14:912-20.

Erickson, S.J. 1972. Toxicity of copper to Thalassiosira pesudonana in unenriched inshore seawater. J. Phycol. $\underline{8}: 318-323$.

Fahrenbach, Wolfgang. Personal communication.

Fisher, Nicholas S. and Gary J. Jones. 1981. Effects of copper and $z$ inc on growth, morphology, and metabolism of Asterionella japonica (Cleve). J. exp. Mar. Bio. Ecol. 51:37-56.

Fitzgerald, G.P. 1975. Factors affecting the algal assay procedure. Report for Office of Research and Monitoring, U.S. Environmental Protection A.gency, Washington, D.C. Project No. P5Jl19l2-J. 3lpp.

Fitzgerald, G.P. and S.L. Faust. 1963. Factors affecting the algicidal and algistatic properties of copper. Applied Micro. 1l:345-351.

Fogg, G.E. 1977. Excretion of organic matter by phytoplankton. Limnol. Oceanogr. 22:576-577.

Foster, P.L. 1977. Copper exclusion as a mechanism of heavy metal tolerance in a green alga. Nature (Lond.) $\underline{269}: 322-323$.

Fox, J.E. 1957. Sexuality in Closterium moniliferun (Abstr.) Phycological soc. Am. News. Bull. 10:72-73. 
Foy, C.D. and G.C. Gerloff. 1972. Response of Chlorella pyrenoidosa to aluminum and low pH. J. Phycol. $\underline{8}: 268-271$.

Fraústo da Silva, J.J.R. and R.J.P. Williams. 1976. Uptake of elements by biological systems. Struct. and Bonding. $\underline{29}: 67-121$.

Frieden, Earl. 1981. The Evolution of Copper Proteins In Sigel, Helmut (Ed.) Metal Ions in Biological Systems Vol. 13. Copper Proteins. Marcel Dekker Inc. N.Y. p. 2 .

Fuhs, G.W. 1969. Phosphorus content and rate of growth in diatoms Cyclotella nana and Thalassiosira fluviatilis. J. Phycol. $5: 312-\overline{32 l .}$

Grant, B.R. and I.M. Turner. 1969. Light stimulated nitrate and nitrite assimilation in several species of algae. Comp. Biochem. Physiol. 19:995-1004.

Gross, R.E., P. Pugno, and W.M. Dugger. 1970. Observations on the mechanisms of copper damage in Chlorella. Plant Physiol. $\underline{46}: 183-185$.

Gurd, Frank R.N. and P.E. Wilcox. 1956. Complex formation between metallic cations and proteins, peptides, and amino acids. Advan. Protein Chem. 11:311-427.

Haberman, Helen M. 1969. Reversal of copper inhibition in chloroplast reactions by manganese. Plant Physiol. $\underline{44}: 331-336$.

Hall, A., A.H. Fielding, and M. Butler. 1979. Mechanisms of copper tolerance in the marine fouling alga Ectocarpus siliculosus: Evidence for an exclusion mechanism. Mar. Biol. (Berl.) 54(3): 195-200.

Harrison, W.G. 1973. Nitrate reductase activity during a dinoflagellate bloom. Limnol. Oceanog. 18:457-465.

Harrison, W.G., R.W. Eppley, and E.H. Renger. 1977. Phytoplankton nitrogen metabolism, nitrogen budgets, and observations on copper toxicity: Controlleả ecosystem pollution experiment. Bull. Mar. Sci. $27(1): 44-57$.

Hassal, K.A. 1963. Uptake of copper and its physiological effects on Chlorella vulgaris. Physiol. Plant $16: 323-332$. 
Hattori, A. 1962a. Light-induced reduction of nitrate, nitrite, and hydroxylamine in a blue-green alga, Anabaena cylindrica. Plant Cell Physiol. (Tokyo). $\underline{3}=355-369$.

Hattori, A. 1962b. Adaptive formation of nitrate reducing system in Anabaena cylindrica. Plant Cell Physiol. (Tokyo). $\underline{3}: 370-377$.

Hewitt, E.J. 1975. Assimilatory nitrate-nitrite reduction. Ann. Rev. Plant Physiol. 26:73-100.

Hogan, Gary D. and Wilfried E. Rauser. 1981. Role of copper binding, absorption, and translocation in copper tolerance of Agrostis gigantea. J. Exp. Bot. $\underline{32(126)}: 27-36$.

Hogetsu, T. and M. Yokoyama. 1979. Light, a nitrogen depleted medium and cell-cell interaction in the conjugation process of Closterium ehrenbergii. Plant and Cell Physiol. 20:811-817.

Hollibaugh, J.T., D.L.R. Seibert, and W.H. Thomas. 1980. A comparison of the acute toxicities of ions of 10 heavy metals to phytoplankton from Saanich Inlet, B.C. Canada. Est. Coast. Water Res. 10:93-105.

Hughes, A.F.W. 1950. The effect of inhibitory substances on cell division. A study of living cells in tissue cultures. Quarterly J. Microscopical Sci. 9l:251279 .

Ichimura, T. 1971. Sexual cell division and conjugationpapilla formation in sexual reproduction of Closterium strigosum. In Proceedings, Seventh International Seaweed Symposium, Sapparo, Japan, pp. 208-214.

Ichimura, T. and M.M. Wabanabe. 1976. Biosystematic studies of the Closterium peracerosum-strigosum-littorale complex. I. Morphological variation among the inbreeding populations and an experimental demonstration for source of the cell size variation. Bot. Mag. Tokyo. 89:123-140.

Jackson, G.A. and J.J. Morgan. 1978. Trace metal-chelator interactions and phytoplankton growth in seawater media; Theoretical analysis and comparison with reported observations. Limnol. Oceanogr. 23:268282. 
Jensen, A., B. Rystad, and S. Melsom. 1976. Heavy metal tolerance of marine phytoplankton II. Copper tolerance of three species in dialysis and batch cultures.

J. exp. Mar. Biol. Ecol. 22:249-256.

Kamp-Nielsen, L. 1971. The effect of deleterious concentrations of mercury on the photosynthesis and growth of Chlorella pyrenoidosa. Physiologia Pl. $\underline{24}: 556-561$.

Kanazawa, T. and K. Kanazawa. 1969. Specific inhibitory effect of copper on cellular division in Chlorella. Plant Cell Physiol. 10:495-502.

Ketchum, B.H. (Ed.) 1972. The Water's Edge: Critical Froblems of the Coastal zone. The MIT

Press Inc. Cambridge Mass. p. 154.

Kiermayer, O. 1970. Causal aspects of morphogenesis in Micrasterias. Ann. N.Y. Acad. Sci. 175:686-701.

Klepper, Lowell and R.H. Hageman. 1969. The occurrence of nitrate reductase in apple leaves. Plant Physiol. $\underline{44}: 110-114$.

Lehninger, Albert L. 1975. Biochemistry. Worth Publishers, Inc. N.Y. P. 723 .

Lerch, Konrad. 1981. The Chemistry and Biology of Copper Metallothioneins. In Helmut Sigel (Ed.) Copper Proteins Vol. 13 in Metal Ions in Biological Systems. Marcel Dekker Inc., N.Y. pp. 299-318.

Lewin, R.A. (Ed.) 1962. Physiology and Biochemistry of Algae. Academic Press. New York.

Lewis, O.A.M., E.F. Watson and E.J. Hewitt. 1982. Determination of nitrate reductase in barley leaves and roots. Ann. Bot. $49: 31-38$.

Lippert, B.E. 1967. Sexual reproduction in Closterium moniliferum and Closterium ehrenbergii. J. Phyco. 13:182-198.

Lippert, B.E. 1969. The effect of carbon dioxide on conjugation in Closterium. XI. Intern. Bot. Congr. Abstracts, Seattle, Wash., p. 129.

Lippert, B.E. 1973. Some factors affecting conjugation in Closterium (Desmidiaceae). Beih. Nova Hedwiga. $\underline{42}$ : $171-177$. 
Lippert, B.E. Personal communication.

Lowe, R.H. and H.J. Evans. 1964. Preparation and some properties of a soluble nitrate reductase from Rhizobium japonicum. Biochim. Biophys. Acta 85: 377 .

McAlice, B.J. 1971. Phytoplankton sampling with the Sedgwick-Rafter cell. Limnol. Oceanog. 16:19-28.

McBrien, D.C.H. and K.A. Hassal. 1965. Loss of cell potassium by Chlorella vulgaris after contact with toxic amounts of copper sulfate. Physiol. Plant. 18: 1059-1065.

McCarthy, James J. and Richard W. Eppley. 1972. A comparison of chemical, isotopic, and enzymatic methods for measuring nitrogen assimilation of marine phytoplankton. Limnol. Oceanog. 17(3):371-382.

McKnight, Diane M. 1979. Interactions between fresh water plankton and copper speciation. Ph.D. Thesis. MIT. Cambridge. 283 pages.

McKnight, Diane. 1981. Chemical and biological processes controlling the response of a freshwater ecosystem to copper stress; A field study of a $\mathrm{CuSO}_{4}$ treatment of Mill Pond-Reservoir, Burlington, Massachusetts. Limnol. Oceanog. 26:518-531.

MacIsaac, J.J. and R.C. Dugdale. 1969. The kinetics of nitrate and ammonium uptake by natural populations of marine phytoplankton. Deep-sea Res. 16:45-57.

MacIsaac, J.J. and R.C. Dugdale. 1972. Interactions of light and inorganic nitrogen in controlling nitrogen uptake in the sea. Deep-sea Res. 19:209-232.

Manahan, S.E. and M.J. Smith. 1973. Copper micronutrient requirement for algae. Environ. Sci. Technol. 7: 829-833.

Mandelli, E.F. 1969. The inhibitory effects of copper on marine phytoplankton. Contrib. in Marine Sci. 14: $47-57$.

Martin, D.F. 1967. Coordination chemistry of the oceans in Gould, R.F. (Ed.) Equilibrium concepts in natural water systems, A.C.S. Adv. in Chem. Series 67 . pp. 255-269. 
Moore, G.T. and K.F. Kellerman. 1904. A method of destroying or preventing the growth of algae and certain pathogenic bacteria in water supplies. U.S. Dept. Agr.., Bureau of Plant Industry, Bul. $64,44 \mathrm{pp}$.

Morel, F.M.M., J.G. Rueter, Jr., Donald M. Anderson, and R.R.L. Guillard. 1979. Aquil: A chemically defined phytoplankton culture medium for trace metal studies. J. Phycol. 15:135-141.

Morel, N.M.L., J.G. Rueter, and F.M.M. Morel. 1978. Copper toxicity to skeletonema costatum. J. Phycol. $14: 43-48$.

Morris, I. 1974. Nitrogen assimilation and protein synthesis in Stewart, W.P.D. (Ed.) Algal Physiology and Biochemistry. UC Press, Berkeley. pp. 583-609.

Morris, I. and P.J. Syrett. i963. The development of nitrate reductase in Chlorella and repression by ammonia. Archiv. Mikrobiol. 47:32-41.

Moss, Brian. 1973. The influence of environmental factors on the distribution of fresh water algae: an experimental study. III. Effects of temperature, vitamin requirement, and inorganic nitrogen compounds on growth. J. Ecol. 61:179-192.

Murphy, T.P., D.R.S. Lean and C. Nalewajko. 1976. Bluegreen algae: their excretion of iron-selective chelators enables them to dominate other algae. Science 192:900-902.

Myers, Jack. 1962. Laboratory cultures in Lewin, R.A. (Ed.) Physiology and Biochemistry of Algae. Academic Press, N.Y. pp. 603-615.

Nakajima, A., T. Horikoshi; and T. Sakaguchi. 1977. Chemical state of copper accumulated in Chlorella regularis. J. Agric. Chem. Jap. 51:507-511.

Nriagu, Jerome 0. 1979. The global copper cycle in Copper in the Environment. Jerome O. Nriagu (Ed.). John Wiley and Sons, Inc. New York, p. 13.

Nuzzi, R. 1972. Toxicity of mercury to phytoplankton. Nature 237:38-39. 
Overnell, J. 1975. The effects of heavy metals on photosynthesis and loss of cell potassium in two species of marine algae Dunaliella tertiolecta and Phaeodactylum tricornutum. Mar. Biol. 29:99-103.

Paasche, E. 1973. Silicon and the ecology of marine plankton diatoms I. Thalassiosira pseudonana Hasle and Heimdal (Cyclotella nana Hustedt) grown in a chemostat with silicate as limiting nutrient. Mar. Biol. 19: 117-126.

Passow, H., A. Rothstein, and T.W. Clarkson. 1961. The general pharmacology of the heavy metals. Pharmacol. Rev. 13:185-224.

Petersen, Richard. 1982. Influence of copper and zinc on the growth of a freshwater alga, Scenedesmus guadricauda: the significance of chemical speciation. Env. Sci. \& Tech. 16:443-447.

Pickett-Heaps, Jeremy D. 1973. Stereo-scanning electron microscopy of desmids. J. Microscopy. 91:109-116.

Pickett-Heaps, Jeremy D. and L.C. Fowke. 1971. Conjugation in the desmid Closterium littorale. J. Phycol. $\underline{7}: 37-50$.

Playfair, G.I. 1910. Polymorphism and life-history study in the Desmidiaceae. Proc. Linn. Soc. New South Wales. $35: 459-495$.

Price, C.A. 1970. Molecular Approaches to Plant Physiology. Mc-Graw Hili. New York, p. 204.

Proctor, V.W. 1957. Preferential assimilation of nitrate ion by Haematoccos pluvialis. Am. J. Bot. 44:141143.

Rauser, Wilfried E. and Nester R. Curvetto. 1980. Metallothionein occurs in roots of Agrostis tolerant to excess copper. Nature (Lond.) 2 $2 \overline{87}: 563-564$.

Rosko. J.J. and J.W. Rachlin. 1977. The effect of cadmium, copper, mercury, zinc, and lead on cell division, growth and chlorophyli a content of the chlorophyte Chlorella vulgaris. Bull. Torrey Bot. Club, 104:226233 .

Rothstein, Aser. 1959. Cell membrane as site of action of heavy metals. Fed. Proc. 18:1026-1035. 
Rueter, John Gorham Jr. 1979. The effects of copper and zinc on growth rate and nutrient uptake in the marine diatom Thalassiosira pseudonana. Ph.D. Thesis. MIT. Cambridge. 155 pages.

Rueter, J.G., J.J. McCarthy, and E.G. Carpenter. 1979. The toxic effect of copper on Oscillatoria (Trichodesmium) theibautii. Limnol. Oceanog. 24: $558-562$.

Rueter, J.G., S.W. Chisholm and F.M.M. Morel. 1981. Effect of copper toxicity on silicic acid uptake and growth of Thalassiosira pseudonana. J. Phyco. 17:270-278.

Russel, G. and O.P. Morris. 1970. Copper tolerance in the marine fouling alga Ectocarpus siliculosus. Nature 228:288-289.

Sato, Mitsuhiko. 1980. Reactivation by copper of phenolase pre-inactivated by oxalate. Phytochemistry 19:19311933.

Shioi, Y., H. Tamai, and T. Sasa. 1978a. Effects of copper on photosynthetic electron transport systems in spinach chloroplasts. Plant Cell Physiol. 19:203-209.

Shioi, Yuzo, Hiroko Tamai and Tsutomu Sasa. $1978 \mathrm{~b}$. Inhibition of photosystem II in the green alga Ankistrodesmus falcatus by copper. Physiol. Plant.

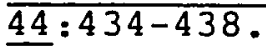

Starr, Richard C. 1955. Isolation of sexual strains of placoderm desmids. Bull. Torrey Bot. Club. 82: 261-265.

Starr, Richard C. 1978. The culture collection of algae at the University of Texas. J. Phycol. Suppl. 14: 47-100.

Steemann Nielsen, E. and L. Kamp-Nielsen. 1970. Influence of deleterious copper concentrations on growth of Chlorella pyrenoidosa. Physiol. Plant. 23:828-840.

Steemann Nielsen, E., L. Kamp-Nielsen, and S. WiumAndersen. 1969. The effect of deleterious concentrations of copper on photosynthesis of Chlorella pyrenoidosa. Physiologia P1. 222:1121-1133.

Steemann Nielsen, E. and S. Wium-Andersen. 1970. Copper ions as poison in the sea and fresh water. Mar. Biol. 6: 93-97. 
Stern, H. 1956. Sulfhydryl groups and cell division. Science 124: 1292-1293.

Stock, W.D. and O.A.M. Lewis. 1982. Extraction of nitrate reductase from members of the South African Protsaceae. S. Afr. J. Bot., l1(4): 1982 .

Stokes, Pamela M. 1979. Copper accumulations in freshwater biota. In Jerome O. Nriagu (Ed.) Copper in the Environment Part 1: Ecological Cycling. John Wiley and Sons, Inc., New York, pp. 357-381.

Stokes, Pamela M., T.C. Hutchinson, and K. Krauter. 1973. Heavy metal tolerance in algae isolated from contaminated lakes near Sudbury, Ontario. Can. J. Bot. 51: 2155-2168.

Stokes, Pamela M., J. Maler, and J. Riordan. 1977. A low molecular weight copper binding protein in a copper tolerant Scenedesmus in D.D. Hemphill (Ed.). Trace Substances in Environmental Health XI. University of Columbia, Missouri, pp. $1 \overline{47-155 .}$

Strickland, J.D.H. and T.R. Parsons. 1972. A practical handbook of seawater analysis. 2nd edition. Bull. Fish. Res. Bd. Ottawa, Can. No. 167. 311 pages.

Stross, R.G. 1963. Nitrate preference in Haematococcus as controlled by strain, age of inoculum, and $\mathrm{pH}$ of medium. Can. J. Microbiol. 9:33-40.

Stumm, Werner and James J. Morgan. 1970. Aquatic Chemistry An Introduction Emphasizing Chemical Equilibria in Natural Waters. Wiley-Interscience (John Wiley \& Sons Inc.). N.Y. p. 270.

Sunda, W.G. 1975. The relationship between cupric ion activity and the toxicity of copper to phytoplankton. Ph.D. Thesis. Woods Hole Oceanographic Instit. Woods Hole, Massachusette. 167 pages.

Sunda, W.G. and P.A. Gillespie. 1979. The responses of a marine bacterium to cupric ion and its use to estimate cupric ion activity. J. Mar. Res. 37:761777 .

Sunda, W. and R.R.L. Guillard. 1976. Relationship between cupric ion activity and the toxicity of copper to phytoplankton. J. Mar. Res. 34:511-529. 
Sunda, William G., Richard T. Barber, and Susan A. Huntsman. 1981. Phytoplankton growth in nutrient rich seawater: importance of copper-manganese cellular interactions. J. Mar. Res. 39:567-586.

Swallow, K.C.. J.C. Westall, D.M. McKnight, N.M.L. Morel, and F.M.M. Morel. 1978. Potentiometric determination of copper complexation by phytoplankton exudates. Limnol. Oceanog. 23:538-542.

Sweet, Jim. Personal communication.

Syrett, P.J. 1962. Nitrogen assimilation in Lewin, R.A. (Ed.) Physiology and Biochemistry of Algae. Academic Press, N.Y. pp. 171-188.

Syrett, P.J. 1981. Nitrogen metabolism of microalgae. In Physiological Basis of Phytoplankton Ecology. Trevor Platt (Ed.) Can. Bull. Fish. Aquat. Sci. 210: $186-210$.

Syrett, P.J. and I. Morris. 1963. The inhibition of nitrate assimilation by ammonium in Chlorella. Biochim. Biophys. Acta 67:566-575.

Tassigny, M. 1971. Observations sur les bésoins en vitamines des Desmidiées (Chlorophycees-zygnematales). J. Phycol. $7: 213-215$.

Thomas, W.H. and D.L.R. Seibert. 1977. Effects of copper on the dominance and the diversity of algae: controlled ecosystem pollution experiment. Bull. Mar. Sci. 27:23-33.

Thomas, W.H., J.T. Hollibaugh, and D.L.R. Seibert. 1980. Effects on heavy metals on the morphology of some marine phytoplankton. Phycologia 19:202-209.

Thunmark. S. 1945. Zur Soziologie des süsswassuplanktons. Eine methodologisch-ökologische Studie. Folia Limnol. Scand. $\underline{3}: 1-66$.

Tischner, R. 1976. On the induction of nitrate reductase and nitrite reductase in fully synchronized cultures of Chlorella. Planta (Berl.) 132:285-290.

Topinka, Jerry A. 1978. Nitrogen uptake by Fucus spiralis (Phaeophyceae). J. Phycol. 14:241-247.

Ueno, T. and K. Sasaki. 1978. Light dependency of the mating process of Closterium acerosum. Plant and Cell Physiol. 19:2 $4 \overline{45-252}$. 
Van der Berg, C.M.G., P.T.S. Wong, and Y.K. Chan. 1979. Measurement of complexing materials excreted from algae and their ability to ameliorate copper toxicity. J. Fish. Res. Bd. Can. 36:901-905.

Westall, J.C., J.L. Zachary, and R.M.M. Morel. 1976. MINEQL, a computer program for the calculation of . chemical equilibrium composition of aqueous systems. Water Qaulity Lab., Ralph M. Parsons Lab. Water Resour. Environ. Eng., Mass. Inst. Technol. Techn. Note 18, 91 pages.

Whitton, B.A. 1968. Effect of light on toxicity of various substances to Anacystis nidulans. Plant and Cell Physiol. 9 : 23- 26 .

Young, R.G. and D.J. Lisk. 1972. Effect of copper and silver ions on algae. J. Water Pollut. Control Fed. $\underline{44}$ : $1643-1647$.

Zumft, W.G., A. Paneque, P.J. Aparicio, and M. Losada. 1969. Mechanism of nitrate reduction in Chlorella. Biochem. biophys. Res. Comm. 36:980-986. 
APPENDIX

FRAQUIL MEDIUM

(from Morel et al., 1979) 


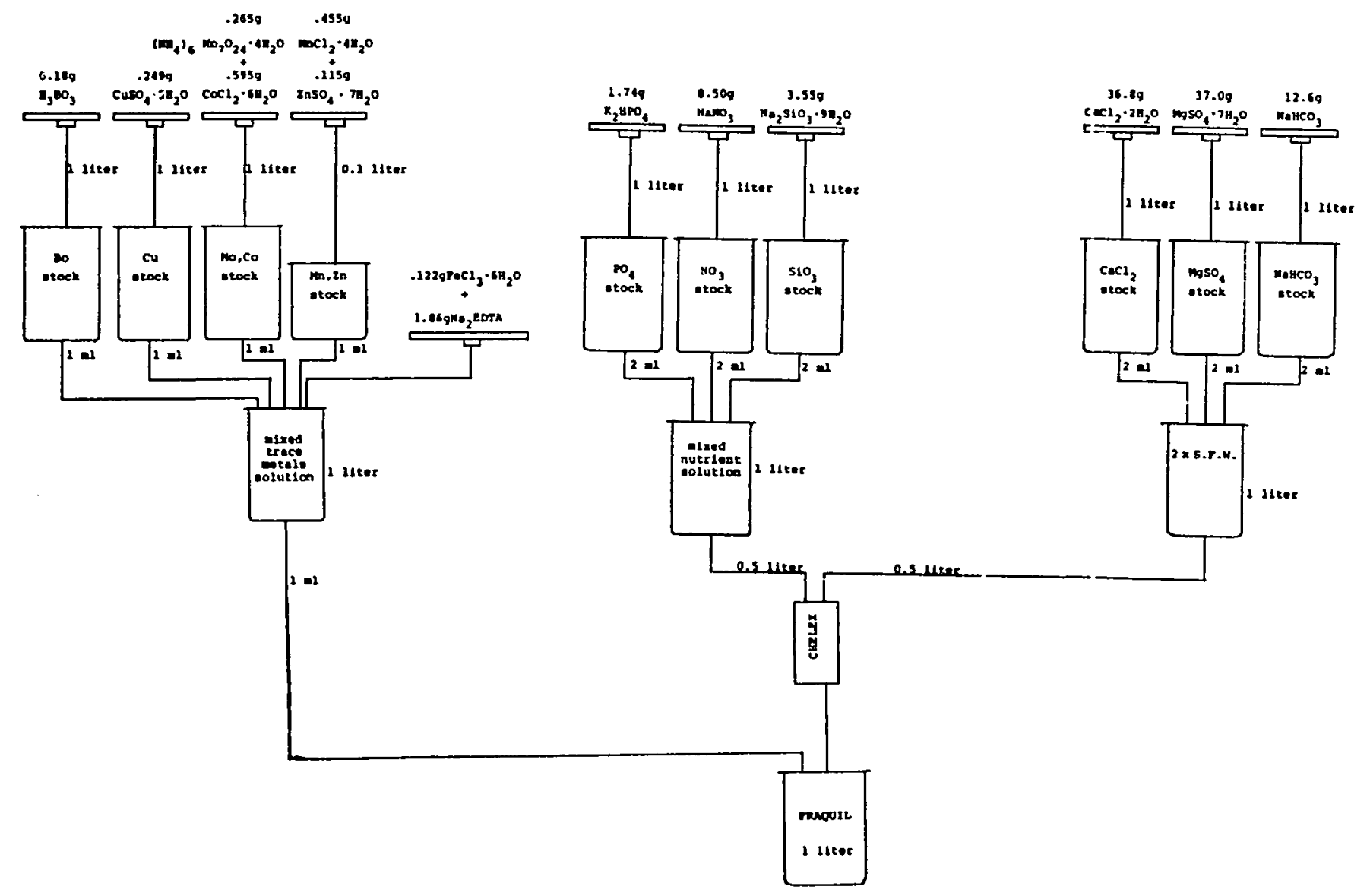


FRAQUIL SALTS (S.P.H.)

\begin{tabular}{|c|c|c|c|c|c|c|c|c|}
\hline mass & SUBSTANCE & $\begin{array}{l}\text { GRAM } \\
\text { FORMUIA } \\
\text { WEIGHT } \\
\end{array}$ & MOLES & $\begin{array}{l}\text { INITIAL } \\
\text { STOCK } \\
\text { VOLUME }\end{array}$ & $\begin{array}{l}\text { INITIAL } \\
\text { STOCK } \\
\text { MOLARITY }\end{array}$ & $\begin{array}{l}\text { DILUTIOA } \\
\text { FACTORS }\end{array}$ & $\begin{array}{l}\text { FINAL } \\
\text { MOLARITY }\end{array}$ & $-200 N$ \\
\hline 36.89 & $\mathrm{CaCl}_{2} \cdot 2 \mathrm{H}_{2} \mathrm{O}$ & 147.02 & $2.50 \times 10^{-1}$ & 12 & $2.50 \times 10^{-1}$ & $500 \times 2$ & $2.50 \times 10^{-4}$ & 3.60 \\
\hline 37.09 & $\mathrm{MgSO}_{4} \cdot 7 \mathrm{H}_{2} \mathrm{O}$ & 246.48 & $1.50 \times 10^{-1}$ & 12 & $1.50 \times 10^{-1}$ & $500 \times 2$ & $1.50 \times 10^{-4}$ & 3.82 \\
\hline 12.69 & $\mathrm{He} \mathrm{HCO}_{3}$ & 84.01 & $1.50 \times 10^{-1}$ & 12 & $1.50 \times 10^{-1}$ & $500 \times 2$ & $1.50 \times 10^{-4}$ & 3.82 \\
\hline
\end{tabular}

\section{NUTRIENTS}

$\begin{array}{ll}\text { MASS } & \text { SUBSTANCE } \\ 1.74 \mathrm{~g} & \mathrm{~K}_{2} \mathrm{HPO}_{4} \\ 8.50 \mathrm{~g} & \mathrm{NaNO}_{3} \\ 3.55 \mathrm{~g} & \mathrm{Na}_{2} \mathrm{SHO}_{3} \cdot 9 \mathrm{H}_{2} \mathrm{O}\end{array}$

\section{Gram}

INITIAL INITIAL

STOCK STOCK DILUTION FINAI

\begin{tabular}{|c|c|c|c|c|c|c|}
\hline $\begin{array}{l}\text { FORMULA } \\
\text { WEIGHT }\end{array}$ & MOLES & $\begin{array}{l}\text { STOCK } \\
\text { VOLUME } \\
\end{array}$ & $\begin{array}{l}\text { STOCK } \\
\text { MOLARITY }\end{array}$ & $\begin{array}{l}\text { DILUTION } \\
\text { EACTORS }\end{array}$ & $\begin{array}{l}\text { FINAL } \\
\text { MOLARITY }\end{array}$ & $-L O G M$ \\
\hline 174.18 & $1.00 \times 10^{-2}$ & 16 & $1.00 \times 10^{-2}$ & $500 \times 2$ & $1.00 \times 10^{-5}$ & 5.00 \\
\hline 84.99 & $1.00 \times 10^{-1}$ & 12 & $1.00 \times 10^{-1}$ & $500 \times 2$ & $1.00 \times 10^{-4}$ & 4.00 \\
\hline 84.20 & $1.25 \times 10^{-2}$ & 12 & $1.25 \times 10^{-2}$ & $500 \times 2$ & $1.25 \times 10^{-5}$ & 4.90 \\
\hline
\end{tabular}

\section{TRACE METALS}

MASS SUBSTANC

$.249 \mathrm{~g} \mathrm{CuSO} \mathrm{C}_{4} \cdot 5 \mathrm{H}_{2} \mathrm{O}$

\section{GRAM}

INITIAL INITIN

STOCK STOCK DILUTION

FORHULA HOLES

$249.689 .97 \times 10^{-4}$$$
\text { (1) }
$$

$.265 \mathrm{~g}\left(\mathrm{NH}_{4}\right)_{6} \mathrm{HO}_{7} \mathrm{O}_{24} \cdot 4 \mathrm{H}_{2} \mathrm{O} 1235.861 .50 \times 10^{-3}$

$.595 \mathrm{~g} \mathrm{COCl}_{2} \cdot 6 \mathrm{H}_{2} \mathrm{O}$

$237.952 .50 \times 10^{-3}$

12

9.

$.455 \mathrm{~g} \mathrm{MnCl}_{2} \cdot \mathrm{HH}_{2} \mathrm{O}$

$197.912 .30 \times 10^{-3}$

12

$.115 \mathrm{~g} 2 \mathrm{nSO}_{4} \cdot 7 \mathrm{H}_{2} \mathrm{O}$

$287.541 .00 \times 10^{-4} 0.1$

$270.321 .51 \times 10^{-4}$

0.11

$10^{3} \times 10^{3}$

FINAL

MOLARITY $-100 N$

$.122 \mathrm{PeCl}_{3} \cdot 6 \mathrm{H}_{2} \mathrm{O}$

$372.245 .00 \times 10^{-3}$

11

$1.50 \times 10^{-3}$

9.00

$1.86 \mathrm{~g} \mathrm{Na} 2$ EDTA

$61.831 .00 \times 10^{-1}$

$2.50 \times 10^{-3} 10^{3} \times 10^{3}$

$2.30 \times 10^{-2} 10^{3} \times 10^{3}$

$4.00 \times 10^{-3} 10^{3} \times 10^{3}$

$1.50 \times 19$

$6.18 \mathrm{~g} \mathrm{H}_{3} \mathrm{BO}_{3}$

$4.51 \times 10^{-4} \quad 10^{3}$

$2.50 \times 10^{-9}$

$2.30 \times 10^{-8}$

$4.00 \times 10^{-9}$

7.64

8.40

6.35

$12 \quad 5.00 \times 10^{-3} \quad 10^{3} \quad 5.00 \times 10^{-6}$

5.30

7.00 